WSRC-TR-2003-00037, REV. 0

SRT-RPP-2003-00006, REV. 0

\title{
PILOT SCALE TESTING - TRANSPORT OF HLW GLASS FORMER CHEMICALS PROOF OF PRINCIPLE TEST RESULTS (U)
}

February 26, 2003

Waste Treatment Technology

Immobilization Technology Section

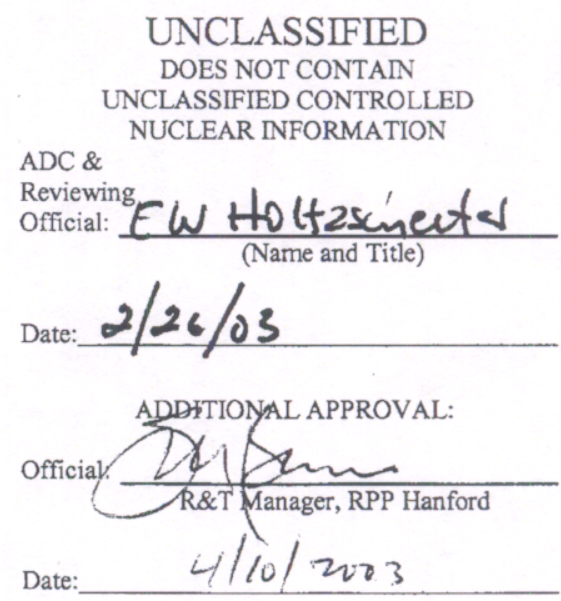

Westinghouse Savannah River Company

Savannah River Site

Aiken, SC 29808

Prepared for the U.S. Department of Energy Under Contract Number DEAC09-96SR18500

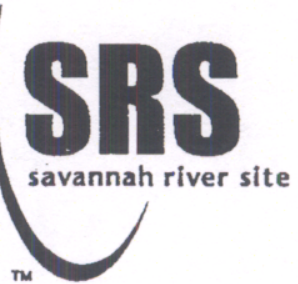


This document was prepared in conjunction with work accomplished under Contract No. DE-AC09-96SR18500 with the U. S. Department of Energy.

\section{DISCLAIMER}

This report was prepared as an account of work sponsored by an agency of the United States Government. Neither the United States Government nor any agency thereof, nor any of their employees, makes any warranty, express or implied, or assumes any legal liability or responsibility for the accuracy, completeness, or usefulness of any information, apparatus, product or process disclosed, or represents that its use would not infringe privately owned rights. Reference herein to any specific commercial product, process or service by trade name, trademark, manufacturer, or otherwise does not necessarily constitute or imply its endorsement, recommendation, or favoring by the United States Government or any agency thereof. The views and opinions of authors expressed herein do not necessarily state or reflect those of the United States Government or any agency thereof.

This report has been reproduced directly from the best available copy.

Available for sale to the public, in paper, from: U.S. Department of Commerce, National Technical Information Service, 5285 Port Royal Road, Springfield, VA 22161, phone: (800) 553-6847, fax: (703) 605-6900

email: orders@ntis.fedworld.gov

online ordering: http://www.ntis.gov/help/index.asp

Available electronically at http://www.osti.gov/bridge

Available for a processing fee to U.S. Department of Energy and its contractors, in paper, from: U.S. Department of Energy, Office of Scientific and Technical Information, P.O. Box 62, Oak Ridge, TN 37831-0062,

phone: (865)576-8401,

fax: (865)576-5728

email: $\underline{\text { reports@ adonis.osti.gov }}$ 
Key Words:

Bulk solids, airborne particles, GFC chute, off-gas line, and GFCs adhering to surfaces

\title{
Retention: Permanent
}

Key WTP R\&T References:

Test Specification: 24590-HLW-TSP-RT-02-007, Rev. 0 Test Plan: WSRC-TR-2002-00323, Rev. 0

Test Exceptions: 24590-WTP-TEF-RT-02-067

24590-WTP-TEF-RT-02-080

Test Scoping Statement: S-29

\section{PILOT SCALE TESTING - TRANSPORT OF HLW GLASS FORMER CHEMICALS PROOF OF PRINCIPLE TEST RESULTS (U)}

Erich Hansen, SRTC, 773-41A

\author{
John Harden, CETL
}

ISSUE DATE: FEBRUARY 26, 2003

Westinghouse Savannah River Company Savannah River Site Aiken, SC 29808

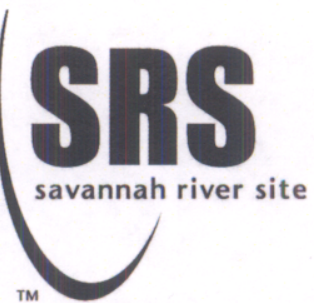


This page intentionally left blank 


\section{TABLE OF CONTENTS}

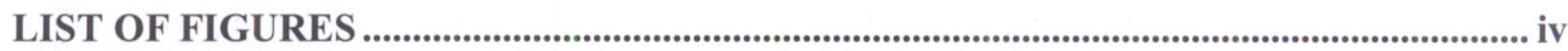

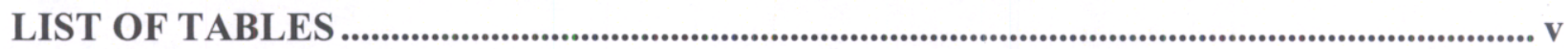

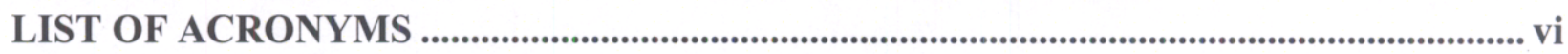

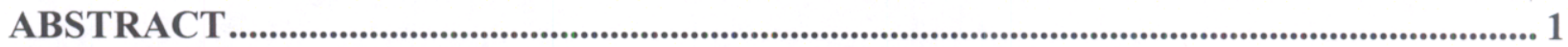

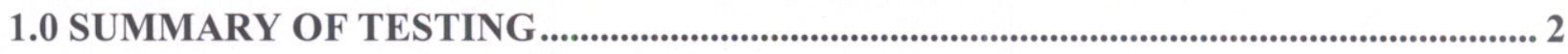

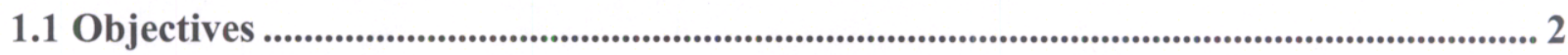

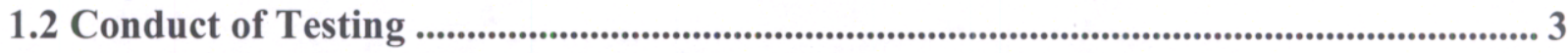

1.3 Results and Performance Against Objectives ............................................................... 6

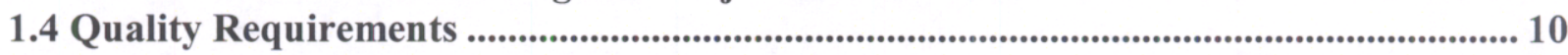

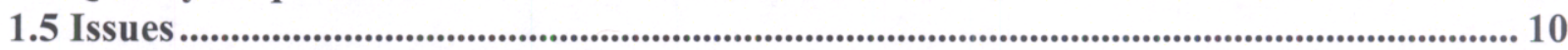

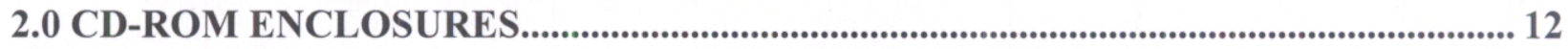

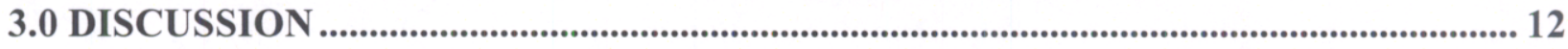

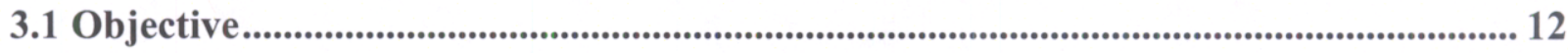

3.2 QA Requirements ........................................................................................................................ 12

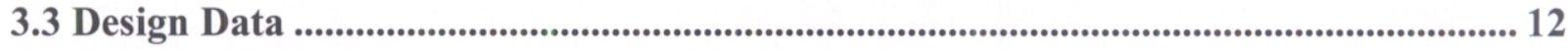

3.4 Pilot Facility Sizing.............................................................................................................. 16

3.4.1 Average Maximum Drop From GFC Addition To Sludge Level ............................ 17

3.4.2 Vapor Space Turnover And Air Purge Rate ............................................................ 19

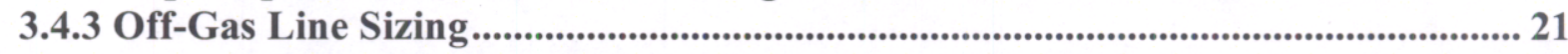

3.4.4 GFC Addition Rate and Chute Size......................................................................... 22

3.4.5 Summary of Operating Parameters Between the Process and Pilot ...................... 23

3.5 Pilot Facility Fabrication - Installation ................................................................... 23

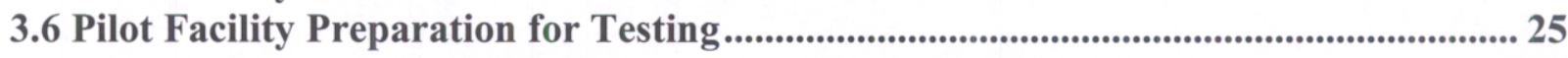

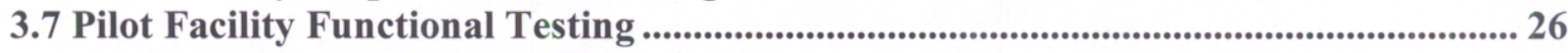

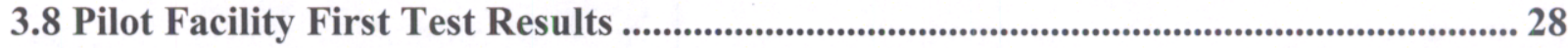

3.9 Pilot Facility Second Test Results ......................................................................................... 31

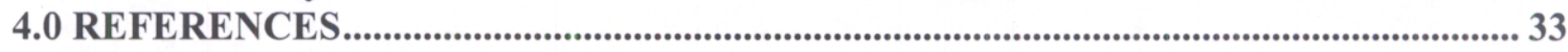

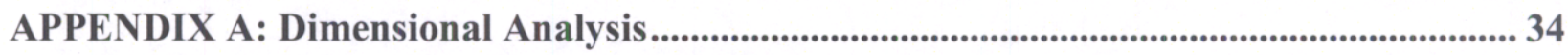

APPENDIX B: Sample Tank Level Calculation ........................................................................... 42

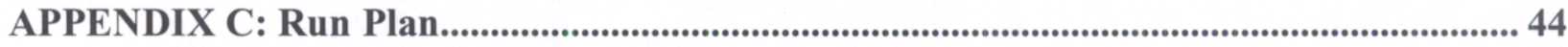

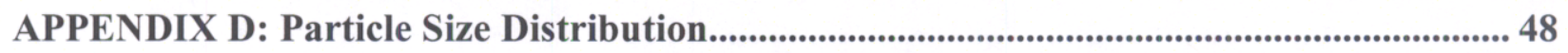




\section{WSRC-TR-2003-00037, REV. 0}

SRT-RPP-2003-00006, REV. 0

\section{LIST OF FIGURES}

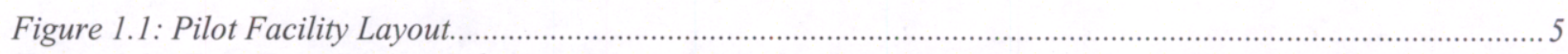

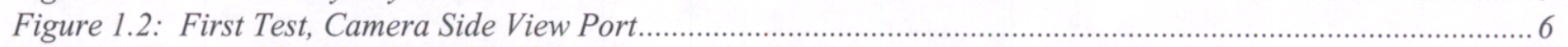

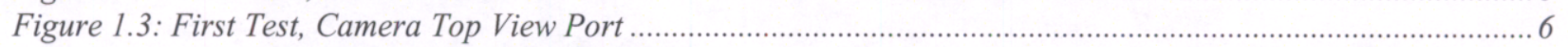

Figure 1.4: Second Test, Observation Side View Port ……….................................................................. 7

Figure 1.5: Second Test, Camera Side View Port ………….............................................................................

Figure 1.6: Second Test, Camera Top View Port...................................................................................... 7

Figure 1.7: First Test, Looking Up into $2^{\text {nd }}$ elbow of the S/S Chute Section ......................................................... 8

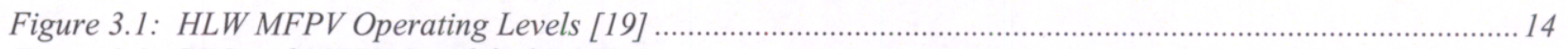

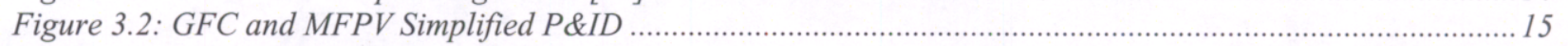

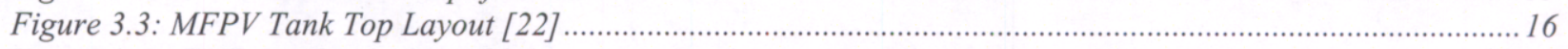

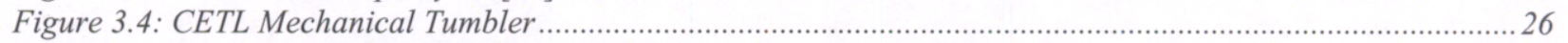

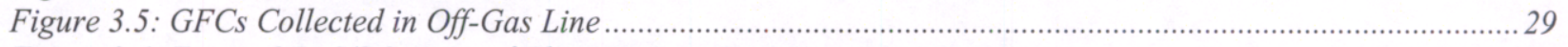

Figure 3.6: Figure 8 In S/S Section of Chute in First Run .......................................................................... 30

Figure D.1: SRA150 Volume Particle Size Distribution First Run Piping............................................................ 49

Figure D.2: SRA150 Number Particle Size Distribution First Run Piping ......................................................... 50

Figure D.3: X100 Volume Particle Size Distribution First Run Piping ............................................................... 51

Figure D.4: X100 Number Particle Size Distribution First Run Piping ...........................................................52

Figure D.5: SRA150 Volume Particle Size Distribution Second Run Piping ........................................................53

Figure D.6: SRA150 Number Particle Size Distribution Second Run Piping ....................................................... 54

Figure D.7: X100 Volume Particle Size Distribution Second Run Piping ..........................................................55

Figure D.8: X100 Number Particle Size Distribution Second Run Piping..........................................................56

Figure D.9: SRA150 Volume Particle Size Distribution Second Run Filters..........................................................57

Figure D.10: SRA150 Volume Particle Size Distribution Second Run Filters..................................................... 58

Figure D.11: X100 Volume Particle Size Distribution Second Run Filters ..........................................................59

Figure D.12: X100 Number Particle Size Distribution Second Run Filters............................................................ 60 
WSRC-TR-2003-00037, REV. 0

SRT-RPP-2003-00006, REV. 0

\section{LIST OF TABLES}

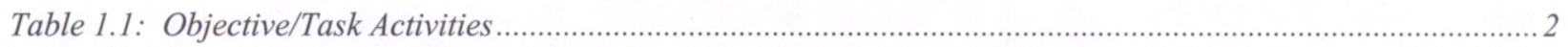

Table 1.2: Operating Parameters during Each Test ............................................................................................ 6

Table 1.3: Mass, Particle Size and Chemical Composition of Collected GFC in the Off-Gas System....................... 10

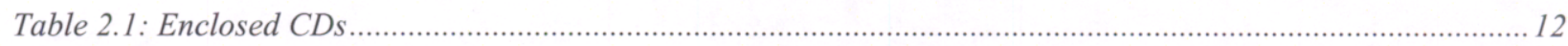

Table 3.1: Design Input Data of RPP-WTP Final GFC Hopper and HLW MFPV ..............................................13

Table 3.2: Nomenclature of Variables Used In Pilot Facility Calculations............................................................17

Table 3.3: Maximum Drop For Various HLW Blends....................................................................................... 19

Table 3.4: Maximum GFC Flow Rates In Various Sized Piping ............................................................................22

Table 3.5: Operating Parameters of RPP-WTP Process and Pilot Facility ............................................................ 23

Table 3.6: Equipment and Instrumentation Used in Pilot Facility .........................................................................24

Table 3.7: AZ-101 HLW GFCs Utilization and Blending Composition ..................................................................25

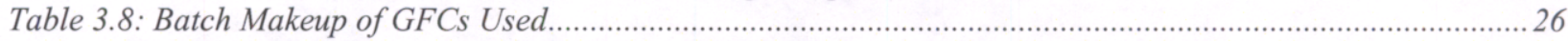

Table 3.9: Observations Noted In Pilot Plant Functional Test ...............................................................................28

Table 3.10: Elemental Composition of Collected Crystals from Pilot Facility Functional Testing .........................28

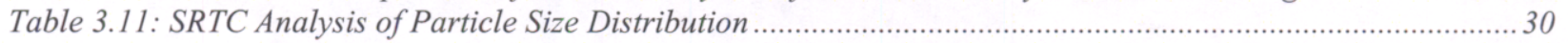


WSRC-TR-2003-00037, REV. 0

SRT-RPP-2003-00006, REV. 0

\section{LIST OF ACRONYMS}

CETL Clemson Environmental Technology Laboratory

GFC Glass Former Chemical

HLW High Level Waste

ICP-ES Inductively Coupled Plasma Emission Spectroscopy

MFPV Melter Feed Preparation Vessel

PVC Poly Vinyl Chloride

QA Quality Assurance

R\&T Research and Technology

RPP River Protection Plant

S/S Stainless Steel

SCFM Standard Cubic Feet Per Minute

SCUREF South Carolina University Research and Education Foundation

SRTC Savannah River Technology Center

WTP Waste Treatment Plant 
WSRC-TR-2003-00037, REV. 0

SRT-RPP-2003-00006, REV. 0

\begin{abstract}
Pilot scale testing of the River Protection Plant (RPP) - Waste Treatment Plant (WTP) High Level Waste (HLW) glass former chemical (GFC) delivery system was performed at Clemson Environmental Technology Laboratory (CETL) under the direction of the Savannah River Technology Center (SRTC). A single HLW GFC blend was tested based on tank AZ-101. Two different tests were performed. The first test was conducted with no chute purge air. The second test was with GFC chute purge air, during which the air was injected upstream of the point where the GFCs were added to the GFC chute. In both tests, the environment in which the tests took place was dry with little to no condensation of water on the surfaces of the tank and off-gas line. The following observations/results were noted:
\end{abstract}

- GFC airborne particles (dust) were generated in both tests. More dust was generated during the test with chute purge air.

- GFC airborne particles deposited in the off-gas line and off-gas line filter(s), adhered to internal tank surfaces and agitator shaft, and were entrained in the agitated water based slurry.

- The mean volume GFC particle size collected in the off-gas lines was $9.7 \mu \mathrm{m}$ and $9.8 \mu \mathrm{m}$ without and with chute purge air, respectively.

- The mean volume GFC particle size collected in the off-gas line filter was $3.5 \mu \mathrm{m}$ with chute purge air.

- Not enough sample material was collected in the off-gas filter during the test without purge air to permit analysis.

- The counter flow of air and GFCs were observed in the vertical section of the transparent Poly Vinyl Chloride (PVC) piping during both tests.

- Visual observation of the vertical section of the off-gas line indicated that some of the GFC particles were agglomerating. Some of the agglomerated particles were seen falling back into the mix tank.

- Visual observation of the sloped GFC chute section, which was made of 304 stainless steel (S/S) pipe, showed a build up of GFCs upstream of the first elbow during both tests. In the first test, GFC build up was also present in the second elbow.

- Visual observation of the transparent PVC piping used in the vertical section of the chute showed no buildup of GFCs, except for the point where the GFCs were being added to the GFC chute. GFCs accumulated in the transparent vertical section of the off-gas line. 


\subsection{SUMMARY OF TES TING}

\subsection{OBJECTIVES}

The objective of this task was to identify potential issues related to the addition of dry GFCs from the final feed hopper to the HLW melter feed preparation vessel (MFPV). The objective defined in the test specification $[1,3,4]$ and the corresponding task activities defined in the test plan [2] are listed in Table 1.1.

Table 1.1: Objective/Task Activities

\begin{tabular}{|c|c|c|c|c|}
\hline Document & Section & Description & Differences & $\begin{array}{c}\text { Met } \\
\text { objective }\end{array}$ \\
\hline \multirow[t]{4}{*}{$\begin{array}{c}\text { Test } \\
\text { specification }\end{array}$} & 3.1 & $\begin{array}{l}\text { Determine if dusting occurs when dry glass former } \\
\text { chemicals are discharged into an enclosed tank with no } \\
\text { agitation and a simple off-gas system. The GFCs were } \\
\text { fed at target flow rates on a smaller, scaled system. }\end{array}$ & $\begin{array}{l}\text { Scaled system included } \\
\text { agitation. }\end{array}$ & Yes \\
\hline & 6 & 2. Provide details of the test facility & & Yes \\
\hline & 6 & $\begin{array}{l}\text { 4. Obtain operating parameters (and basis) used to } \\
\text { conduct test }\end{array}$ & & Yes \\
\hline & 6 & $\begin{array}{l}\text { Scope addressed in the test plan: } \\
\text { 1: Feed GFCs at targeted feed rates } \\
\text { 2. Identify dusting (qualitatively) }\end{array}$ & & Yes \\
\hline \multirow[t]{12}{*}{ Test plan } & III & Obtain SCUREF Contract with CETL & & Yes \\
\hline & III & Obtain Glass Former Chemicals and Batching & & Yes \\
\hline & III & Obtain Design Data & & Yes \\
\hline & III & $\begin{array}{l}\text { Sizing Methodology -Perform calculations for sizing } \\
\text { pilot facility }\end{array}$ & See below. & Yes \\
\hline & III & Dusting Criteria - Analyze collected dust & & Yes \\
\hline & III & Test Matrix - Perform required tests and video record & & Yes \\
\hline & III & Tank and Piping - Use selected materials. & & Yes \\
\hline & III & $\begin{array}{l}\text { Controls and Instrumentation - Measure/control air } \\
\text { flow and GFC addition }\end{array}$ & & Yes \\
\hline & III & HLW Simulant - Use AZ-101 GFC blend & & Yes \\
\hline & III & $\begin{array}{l}\text { Perform work at CETL - Setup pilot facility, } \\
\text { functional test and perform tests. }\end{array}$ & & Yes \\
\hline & III & Write Run Plan & & Yes \\
\hline & III & CETL Quality Assurance & $\begin{array}{l}\text { Particle size and } \\
\text { chemical composition } \\
\text { of collected dust was } \\
\text { performed at SRTC. }\end{array}$ & Yes \\
\hline
\end{tabular}

All of the objective/task activities listed in Table 1.1 were satisfied, except for the bubbler purge rate used in the second test. During this test, the bubbler purge air rate was reduced from 2.4 standard cubic feet per minute (SCFM) to 1.0 SCFM. This reduction was made to accommodate the increased GFC chute purge air within the operating parameters of the pilot off-gas system.

No dusting task acceptance criteria was established [2]. The results from these tests were purely qualitative and were representative of the blend of GFCs processed. This task was not intended to address issues related to blending of GFCs as described in the Test Specification [1]. The scope for blending dry GFCs with waste simulants will be covered under another test plan. 
WSRC-TR-2003-00037, REV. 0

SRT-RPP-2003-00006, REV. 0

\subsection{CONDUCT OF TESTIN G}

The sizing of the pilot facility and the methodology for delivering dry GFCs from the final blend hopper to the HLW MFPV was based on data from the actual RPP-WTP process as referenced in the task plan [2]. Scaling methodology and sizing parameters are summarized below (scaling details are addressed in section 3.4).

- The level of the sludge in the tank was calculated given the different HLW actual waste and simulant physical data, prior to GFC addition. The average vertical drop from the top of the tank to that of the average tank level was also calculated. This average vertical drop was maintained in both plant and pilot. A commercially available pilot tank size was determined based on this vertical drop.

- The vapor space volume in the plant and the pilot facilities was determined based on the average calculated vertical drop.

- The GFC addition rate in the pilot facility was determined by keeping the ratio of GFC addition rate to vapor space volume the same as that of the plant.

- The GFC chute diameter used in the pilot facility was determined using a one-third pipe full rule and this diameter was rounded up to the pipe diameter of commercially available stainless steel pipe.

- The amount of purge air used in the pilot facility was determined by maintaining the same vapor space turnover ratio in the plant and the pilot facilities.

- The same off-gas line velocity was used in the pilot as that of the plant.

The total vertical drop from the discharge point of the feed hopper to the top of the slurry tank level and the length of sloped piping in the plant and pilot facilities are not the same. This is because the layout of the Clemson Environmental Technology Laboratory (CETL) facility and the actual plant are different and also because the isometrics of the GFC chute in the plant were not available at the time these tests started.

The layout of the pilot facility that was installed and fabricated at CETL is shown in Figure 1.1 and was located indoors. The tank was constructed of reinforced fiberglass plastic and contained three view ports; one on the top of the tank and two on the sides of the tank that were 180 degrees apart.

The pilot vessel off-gas line and the GFC addition chute were located geometrically in the same location as that of the HLW MFPV [22]. The vertical sections of the GFC chute and vessel offgas line were constructed from clear PVC pipe. The sloped section of the GFC chute was constructed from commercially available $304 \mathrm{~S} / \mathrm{S}$ pipe.

Dry purge air was introduced into the tank vapor space and also into the agitated water based slurry (bubbler). Airflow was controlled based on the flow splits in the plant $[12,19]$. The offgas line contained two $0.2 \mu \mathrm{m}$ cartridge filters, a flow indicator, a vacuum pump, and a control valve.

During the operations of the test facility, the differential pressure between the tank vapor space and the environment was maintained as close to zero by adjusting the off-gas line control valve. This control was required such that an air balance could be maintained between the supplied air and the off-gas system. If the pilot facility was operated under vacuum then additional air 
WSRC-TR-2003-00037, REV. 0

SRT-RPP-2003-00006, REV. 0

inleakage could have occurred which would have biased the results, by increasing the amount of GFCs collected in the off-gas system. The opposite would have been true if the vapor space was operated with positive pressure.

In both tests, the pilot facility was maintained as a dry system. The exposed internal surfaces of the tank walls, the GFC chute, the off-gas system, and other items not in contact with the agitated water based slurry contained little to no moisture. The water used in these tests was allowed to come to thermal equilibrium with the environment prior to testing. The bubbler purge air was not initiated until two minutes prior to the start of the tests.

Prior to starting the second test, a differential pressure gauge was installed upstream of the GFC addition line on the GFC chute. This gauge was used to regulate the GFC purge air that would provide a differential pressure of zero between the tank vapor space and the GFC chute, at the point where the GFCs were added to the chute. Due to the limitation of the off-gas fan and the rotameters used to control the purge air additions, the bubbler purge rate was reduced (from 2.4 to $1.0 \mathrm{SCFM}$ ) and a maximum attainable chute purge air rate of 4 SCFM was achieved. With the GFC purge rate of 4 SCFM, there was still a negative pressure at the point where the GFCs were added to the GFC chute.

The GFCs used in this task were those approved by RPP-WTP R\&T [5]. An AZ-101 HLW blend, as provided by RPP-WTP R\&T, was used [6]. The individual GFCs were analyzed for moisture content at CETL. No correction was made to the GFC batch based on moisture content. The GFCs were blended using a mechanical tumbler and then fed into the chute using a spiral auger feeder. The operations of the mechanical tumbler occurred outside.

Two different tests were performed. The first test involved feeding the GFCs without chute purge air. The second test involved feeding the GFCs with chute purge air. The information collected during these tests included video tape, photographs, visual observations, mass rate of GFCs added, purge air rates, and mass of GFCs collected in the off-gas lines and off-gas filters. In each test, the water used in the tank was maintained at room temperature, to minimize the effects of condensation of moisture on the internal exposed surfaces of the pilot facility.

The GFC particles collected in the off-gas line and filter were analyzed for particle size distribution and chemical composition at SRTC. These particle size distributions were obtained using MICROTRAC X100 and MICROTRAC SRA150 particle size analyzers, without sonication. The chemical composition were determined via inductively coupled plasma emission spectroscopy (ICP-ES) for the specific GFCs used in these tests.

The information and issues generated in these tests will be provided to RPP-WTP design and process engineering personnel via this report. Means to mitigate GFC dusting issues identified in this report will be addressed by RPP-WTP engineering organizations as necessary. 
WSRC-TR-2003-00037, REV. 0

SRT-RPP-2003-00006, REV. 0

Figure 1.1: Pilot Facility Layout

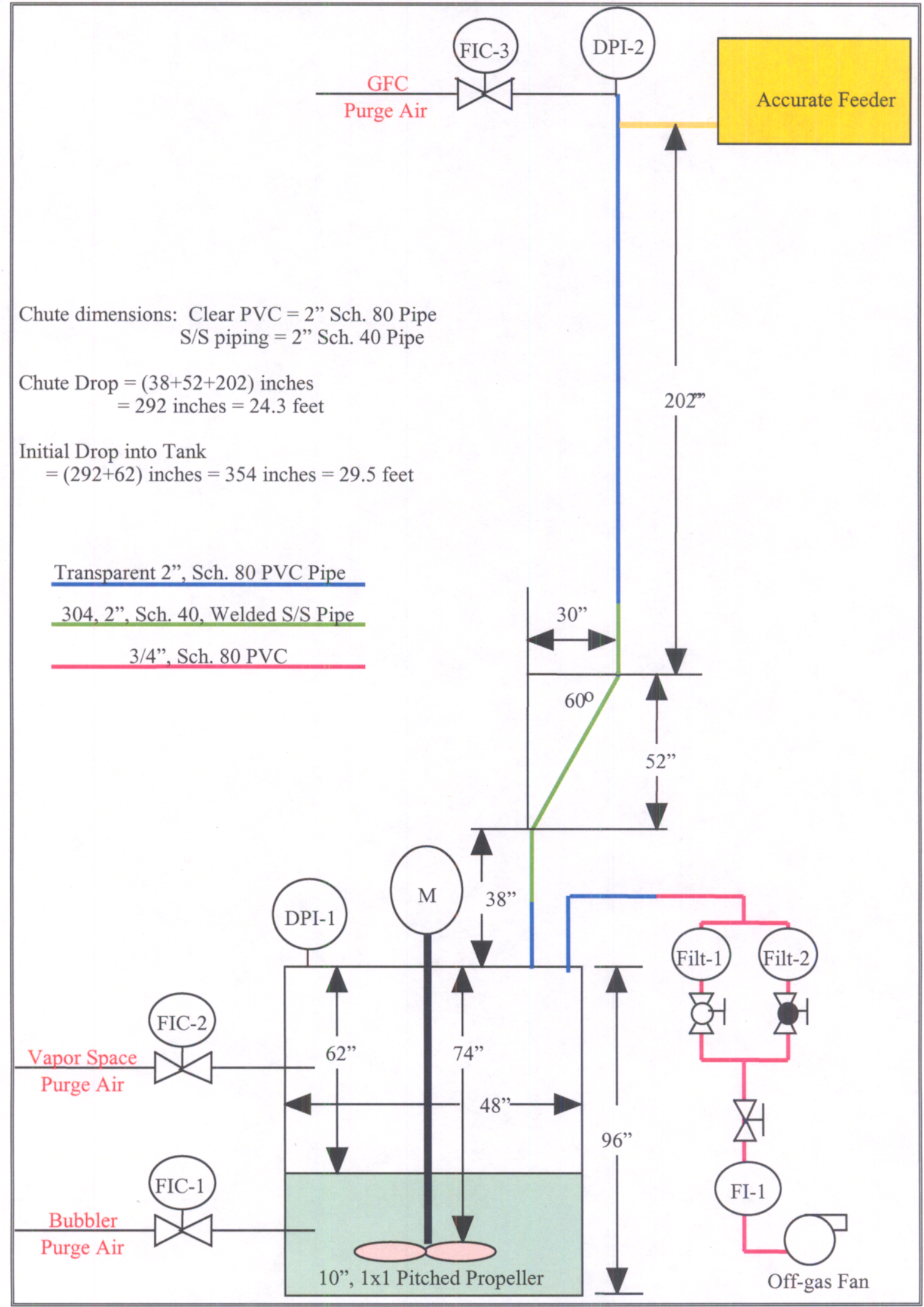

Page 5 of 60 


\subsection{RESULTS AND PERFO RMANCE AGAINST OBJECTIVES}

The operating parameters employed during the two pilot tests are listed in Table 1.2.

Table 1.2: Operating Parameters during Each Test

\begin{tabular}{|c|c|c|}
\hline & $\begin{array}{c}\text { First Test - No Chute } \\
\text { Purge Air }\end{array}$ & $\begin{array}{c}\text { Second Test - With Chute } \\
\text { Purge Air }\end{array}$ \\
\hline Run Time (minutes) & 29 & 27 \\
\hline Mass of GFCs used (lbm) & 690 & 645 \\
\hline GFC addition rate (lbm/hr) & 1430 & 1430 \\
\hline Chute purge air rate (SCFM) & 0.0 & 4.0 \\
\hline Vapor space purge air rate (SCFM) & 1.2 & 1.2 \\
\hline Bubbler purge air rate (SCFM) & 2.4 & 1.0 \\
\hline Off-gas line velocity (ft/sec) & 2.6 & 4.4 \\
\hline Number of off-gas filters run & One bank & Two banks \\
\hline
\end{tabular}

Photographs and digital video were obtained for each test. Digital video of the first and second tests is provided via an enclosed CD. Observations noted in the digital videos and attached photographs are described below. Visual observations are also described below.

- GFC airborne particles (dust) were generated in both tests. More dust was generated in the second test, which had GFC chute purge air. The difference in vapor space dust concentration between each test is unknown, because the concentration $(\mathrm{mg} / \mathrm{L})$ of airborne particles was not measured.

- GFC airborne particles adhered/settled in the off-gas line and off-gas line filter(s), GFCs adhered and accumulated to the internal tank surfaces and agitator shaft. GFCs were entrained in the agitated water based slurry. Figure 1.2 through Figure 1.6 show locations where GFC particles accumulated. These are locations with low flow or dead spots where the GFCs can easily settle, but cannot be re-suspended.

Figure 1.2: First Test, Camera Side View Port

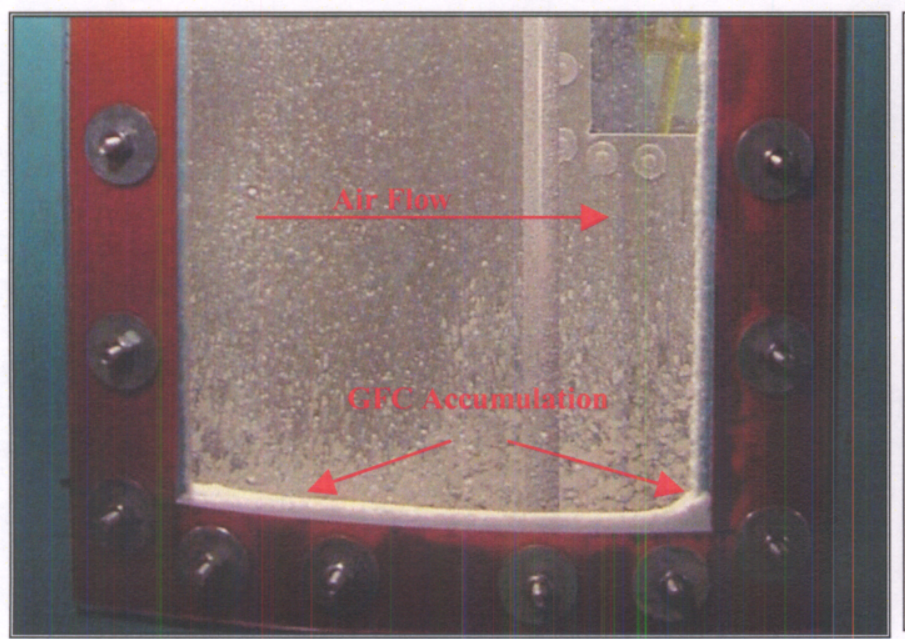

Figure 1.3: First Test, Camera Top View Port

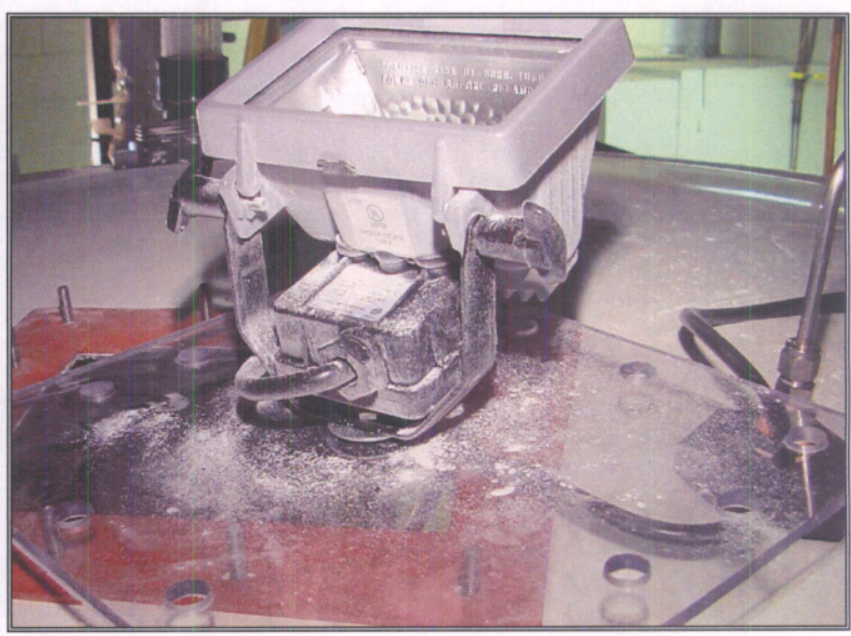


WSRC-TR-2003-00037, REV. 0

SRT-RPP-2003-00006, REV. 0

Figure 1.4: Second Test, Observation Side View Port

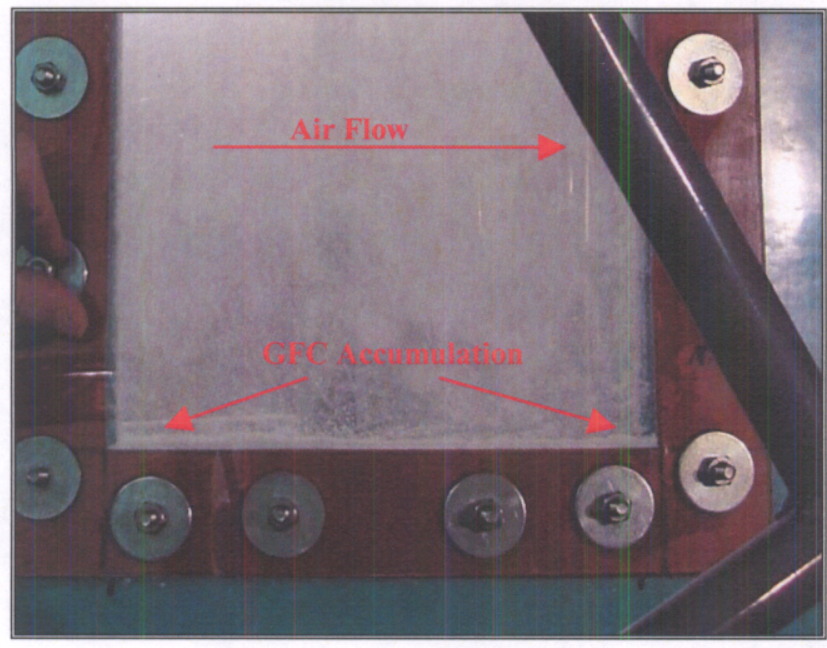

Figure 1.5: Second Test, Camera Side View Port

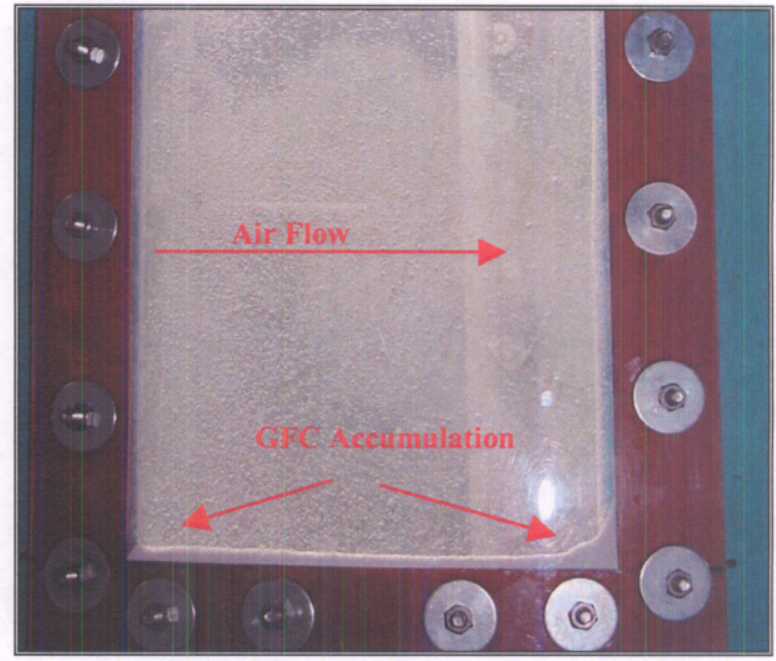

Figure 1.6: Second Test, Camera Top View Port

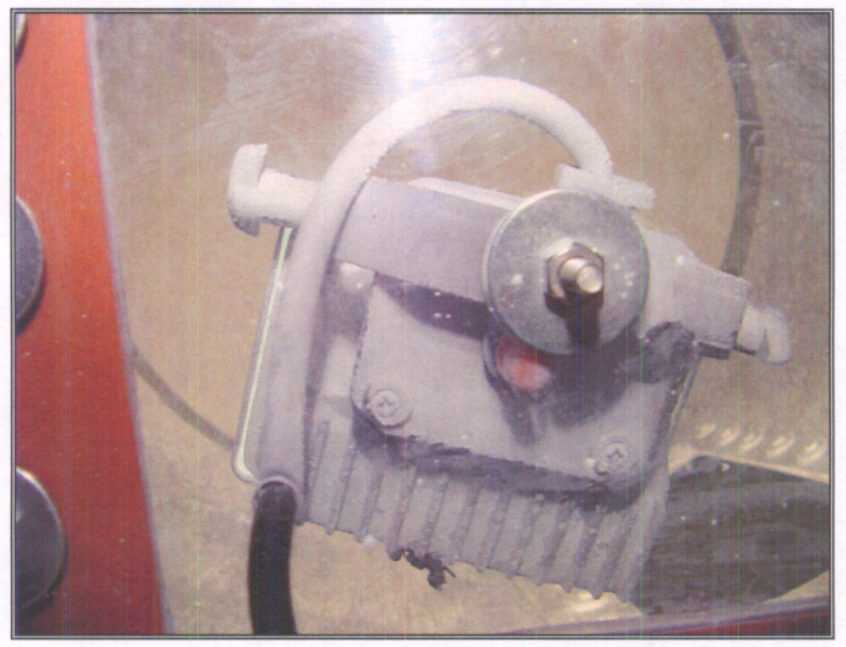

- In the vertical sections of the chute (clear PVC section), re-circulation flow patterns were noted in both tests. These re-circulation (counter flow of GFCs and air with that of falling GFCs) flow patterns were due to the displacement of air by the GFC particles as they traveled down the chute and into the tank. As the GFCs traveled down the chute, the GFC particles displaced the air in the chute, creating a resistance to flow and a vacuum in the chute relative to the tank vapor space.

- In the first test, with no GFC purge air, the re-circulation pattern was very active.

- In the second test, four SCFM purge air was applied upstream of the point where GFCs were fed into the chute, the re-circulation pattern was not as active but was still evident. These re-circulation patterns were recorded in the digital video and were also detected by the pressure sensing instrument upstream of the point where the GFCs were fed into the chute. This instrument measured a negative pressure throughout this test indicating that there was not enough purge air supplied to mitigate the vacuum effect. 
- To totally remove the vacuum effects (re-circulation in the pipe); the pressure at the top of the chute must be made equal to the pressure in the tank vapor space. This condition could not be achieved in the pilot facility because the off-gas system could not handle the additional GFC chute purge air needed to support this.

- The build-up of GFCs upstream of the first elbow in the S/S piping of the GFC chute was evident in both tests.

- The first test showed a greater buildup of solids than the second test.

- The build up of GFCs in the first test resulted in a "figure 8" shape (also see Figure 3.6)

- The build up of GFCs in the second test shows a very slight "figure 8" shape.

- The mechanism for this build up is not completely understood, but could have been due to factors such as:

* Electrostatic attraction between the GFCs and the grounded S/S chute.

* Cohesive forces and impact forces generated by the re-circulation flow patterns immediately upstream of the elbow, which caused the particles to adhere to the S/S surface.

* The buildup of solids on top of solids due to attractive forces between the GFC particles.

* The roughness of the S/S steel pipe.

* Other unidentified attractive forces that may affect the initial buildup of solids on the wall and between the solids.

\section{Figure 1.7: First Test, Looking Up into $2^{\text {nd }}$ elbow of the S/S Chute Section}

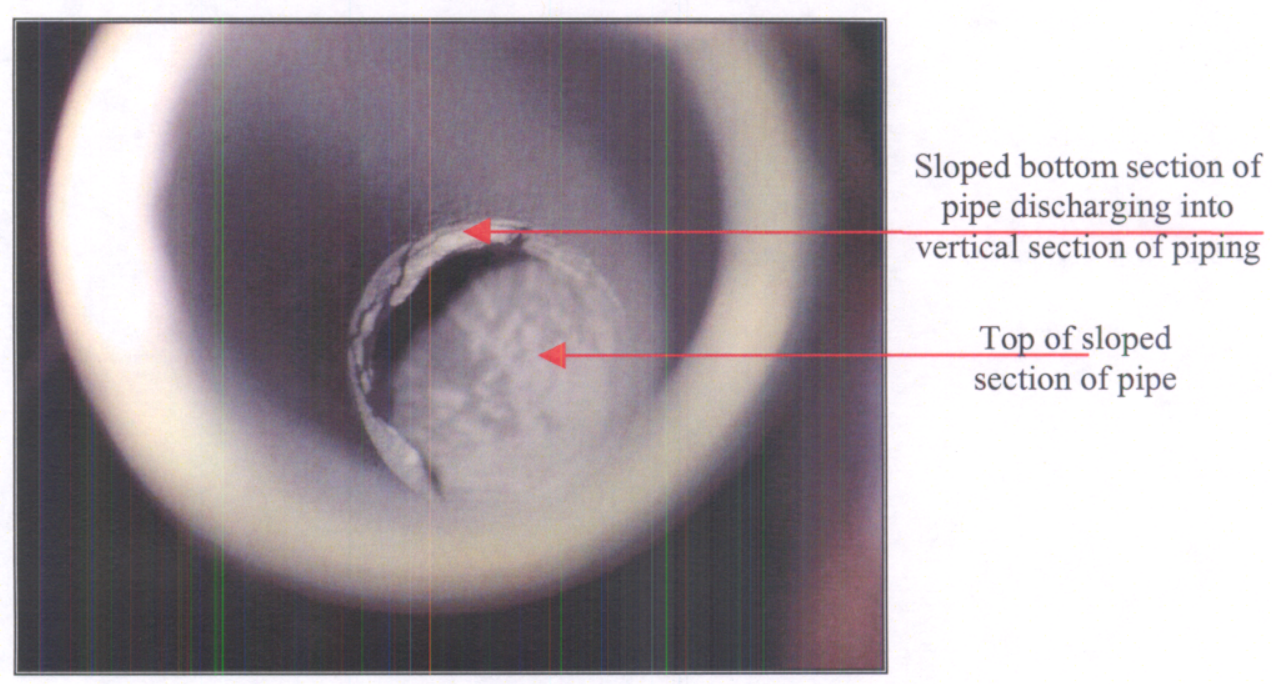

- Figure 1.7 shows slight solids buildup in the $2^{\text {nd }}$ elbow of the $\mathrm{S} / \mathrm{S}$ section of the chute, after completion of the first test. This buildup of GFCs is predominately on the bottom sloped section of the S/S pipe (at a point where the GFCs could potentially slide). There is little to no build up on the top sloped section of the tube or vertical section.

* The buildup of GFCs are due the mechanism as described above.

* Visual inspection of the $2^{\text {nd }}$ elbow after the second test showed little to no buildup of GFCs. 
WSRC-TR-2003-00037, REV. 0

SRT-RPP-2003-00006, REV. 0

* There was no video or still pictures taken showing the internals of the sloped section of S/S piping.

Visual observation of the vertical section of the 2" off-gas line located immediately above the mix tank showed that some of the GFCs were agglomerating and falling back into the mix tank. The GFCs were also adhering to the sides of the transparent PVC pipe used in the vertical section of the off-gas line. The GFCs did not adhere to the sides of the transparent PVC pipe used in the vertical sections of the GFC chute except for the point where the GFCs were added to the chute.

The mass of GFCs collected in the off-gas line, particle size volume/number mean and range of the GFCs, and the chemical compositions of the GFCs were measured. This information is listed in Table 1.3. These results show that a greater mass of GFC material was collected in the second test than in the first test, which most likely was due to the addition of the GFC purge air. The addition of GFC purge air created an overall increase in the off-gas line velocity. Also worth noting is that the particle size distributions and chemical compositions of the GFCs collected in the off-gas lines were about the same for both tests. The difference between the analyses of the GFCs accumulated in the pipe and those that accumulated in the filter during the second test may be due to the fact that the piping was trapping the large particles (product of mass and diameter) used in the off-gas system. The details of these results are provided in section 3.9.

After the first test and prior to the second test, pressurized air (via a nozzle) was used to remove the accumulated GFCs out of the S/S section of the chute. The distance from the nozzle to the buildup was less than 2.5 feet.

Some of the handling issues associated with the GFC blends are also worth noting:

- During the transfer of blended GFCs from the mechanical tumbler to the 55 gallon drums, the GFC material bridged on the inside of the tumbler.

- The cohesive nature of the blended GFCs limited the rate at which the auger could deliver the material. 
WSRC-TR-2003-00037, REV. 0

SRT-RPP-2003-00006, REV. 0

Table 1.3: Mass, Particle Size and Chemical Composition of Collected GFC in the Off-Gas System

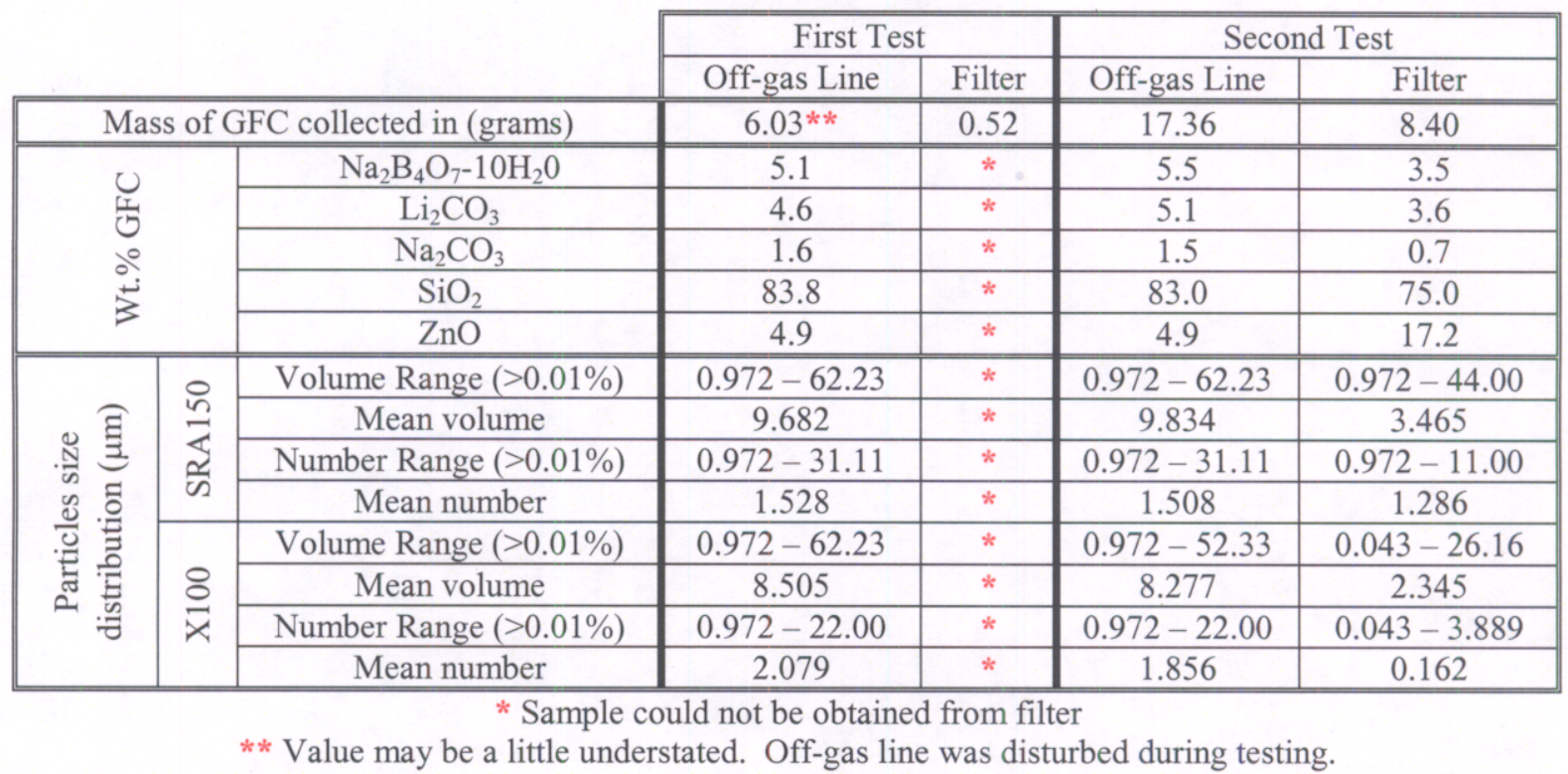

\subsection{QUALITY REQUIREMENTS}

This work was conducted in accordance with the RPP-WTP QA requirements specified for work conducted by SRTC as identified in DOE IWO MOSRLE60. SRTC has provided matrices to WTP demonstrating compliance of the SRTC QA program with the requirements specified by WTP. Specific information regarding the compliance of the SRTC QA program with RW0333P, Revision 10, NQA-1 1989, Part 1, Basic and Supplementary Requirements and NQA-2a 1990, Subpart 2.7 is contained in these matrices.

Per the test specification [1], the activities performed during this testing were not IHLWaffecting therefore RW-0333P does not apply.

The Task Technical and Quality Assurance Plan [2] governs how SRTC performed this task and the QA requirements. The Quality Assurance Project Plan [7] governs how CETL, under SRTC's SCUREF contract, performed this task and the QA requirements. The task was performed applying the appropriated quality assurance requirements from NQA-1-1989, and NQA-2a-1990 as indicated by the reference Task Technical and Quality Assurance Plan (SRTC) and Quality Assurance Project Plan (CETL).

\subsection{ISSUES}

Based on the results of these tests, issues have been identified that could potentially impact the operations of the GFC delivery system and the associated HLW MFPV processes. The issues identified are summarized below:

- GFC Chute operations:

- The mechanisms causing the buildup of GFCs in the S/S piping section of the chute were not fully understood. Nonetheless, these buildups could potentially plug the chute line. 
This plug would be difficult to remove under radioactive conditions. The buildup of GFCs occurred in both tests, with and without purge air. The purge air used in this test reduced the amount of buildup when compared to the test without purge air.

- The GFC buildup was removed between the two runs. There is no data showing how this GFC buildup could impact subsequent feeds or if this buildup would change in size over time.

- The rate and quantity of air used to remove the GFC buildup between the $1^{\text {st }}$ and $2^{\text {nd }}$ tests was not quantified. If pressurized air is used as a means for removing the buildup of GFCs in the process, then the rate, quantity and point of application will need to be quantified. This rate of air addition must be accommodated by the MFPV off gas system.

- A negative pressure in the GFC chute could cause counter flow of the materials in the MFPV vapor space. If the vapor in the MFPV vapor space contains high moisture, the moisture could condense on the inner walls of the chute at the discharge point. The dry GFCs are likely to adhere to the condensed moisture and could potentially plug the chute discharge (over time).

- The circulation of air from the MFPV vapor space could traverse up the chute and contaminate the GFC delivery system.

- The GFC airborne particles (dust) were very evident and will impact the operation of the HLW MFPV by:

- Potentially plugging the off-gas line over time.

- Adhering to the internal components and the walls of the MFPV, building up over time and breaking off into the slurry. This could impact operations of other systems such as the sampling process or pump operations.

- Plugging the vessel overflow line in the MFPV, due to the accumulation of GFC solids.

- The results from this test were based on a single HLW GFC blend only. Therefore, this test may not fully describe how other GFC blends will behave. Testing of other GFC blends with bounding physical properties will be necessary to determine if there are issues that were not revealed during these tests.

- The effect of different GFC mass feed rates and GFC air purge rates should also be investigated to determine their impacts on dusting. Presently there is no knowledge of potential issues concerning the entrainment of GFCs with the vessel mixing systems to be used by RPP-WTP because the vessel mixing systems have yet to be designed.

- Use of purge air in the chute could potentially impact the operation of the rotary valve used to feed the GFCs from the final feed hopper into the GFC chute. Positive pressure on the discharge side of the rotary valve could force air back up through the rotary valve and into the hopper, thus limiting the dry solids discharge rate.

- During normal operations of the MFPV, the operating temperature of the slurry will be elevated relative to the ambient temperature of the cell in which the MFPV operates. Moisture will deposit on the MFPV internals, which are located in the vapor space. This moisture will cause the GFCs to adhere to the exposed surfaces. This moisture and GFCs may react to form a hard compound. This compound could be difficult to remove and will grow over time as more GFCs accumulate on the exposed surfaces. 


\subsection{CD-ROM ENCLOSU RES}

The following CD-ROMs are enclosed with this report

Table 2.1: Enclosed CDs

\begin{tabular}{|l|l|}
\hline CD name & Contains \\
\hline $\begin{array}{l}\text { Proof-of-Principle Pilot Scale Test } \\
\text { To Investigate Dusting Videos }\end{array}$ & $\begin{array}{r}\text { POP1 Test 1 - Video clips of the first test, which does not have GFC purge air. } \\
\text { Windows Media Player can view this video. }\end{array}$ \\
\hline REPORT & $\begin{array}{r}\text { POP1 Test 2 - Video clips of the second test, which does not have GFC purge } \\
\text { air. Windows Media Player can view this video. }\end{array}$ \\
\hline
\end{tabular}

In the POP1 Test 1 and POP1 Test 2 digital videos, the "Fixed Side" is denoted. This means that the camera was fixed to record from only one of the tank side view ports.

\subsection{DISCUSSION}

\subsection{OBJECTIVE}

The objective of this task was to identify any issues related to the present method of adding GFCs to the MFPV. The present method is to deliver dry GFCs to the MFPV from a feed hopper located above the MFPV. The overall test objectives were met qualitatively by providing digital video footage and photographs from the testing. Quantitative measurements including mass, particle size distribution, and chemical composition were performed on the GFCs collected in the off-gas line.

There were two different tests performed; one with and one without purge air supplied to the GFC delivery chute. The GFCs used during testing were those specified by the project [2]. Only one HLW GFC blend was tested.

\subsection{QA REQUIREMENTS}

The QA requirements are stated in Reference 7 for CETL. The weighing devices used to batch the GFCs, to perform moisture analyses, and to weigh the off-gas filters were calibrated. SRTC specified and verified that the proper GFCs were procured by CETL. SRTC specified the construction materials used in the pilot facility and all items were procured as specified by SRTC and by CETL.

The QA requirements are stated in Reference 2 for SRTC.

\subsection{DESIGN DATA}

The design information and physical data used during these tests was obtained from RPP-WTP Process Engineering personnel. The relevant information necessary for sizing the pilot facility is listed in Table 3.1. Figure 3.1 and Figure 3.2 show the operating levels in the HLW MFPV and the physical location between the final HLW GFC feed hopper and HLW MFPV respectively. 
WSRC-TR-2003-00037, REV. 0

SRT-RPP-2003-00006, REV. 0

Figure 3.3 shows the layout of the HLW MFPV tank top, which depicts the location of the offgas and GFC nozzles.

\section{Table 3.1: Design Input Data of RPP-WTP Final GFC Hopper and HLW MFPV}

\begin{tabular}{|c|c|c|}
\hline I: & \multicolumn{2}{|c|}{ Glass former discharge rate into the blend vessel. [8, 9, 10, and 11] } \\
\hline \multicolumn{3}{|c|}{\begin{tabular}{l|ll} 
& Mass flow rate $=6000$ to $10,000 \mathrm{lbm} / \mathrm{hr}$ & Drop from rotary valve discha \\
- $\quad$ Chute size $=4$ " or 6", sch. 40 pipe? & tank $=44$ feet +8 inches $=53$ \\
- Make of material: unknown. & \\
\end{tabular}} \\
\hline & Working volume and dimensions of Melter $\mathrm{F}$ & ed Preparation Vessel. $[12,13,14]$ \\
\hline \multicolumn{2}{|c|}{$\begin{array}{l}\text { - } \\
\text { - } \\
\text { - Notal volume: } 8458.5 \text { gallons } \\
\text { - Nominal working volume: } 7153.4 \text { gallons } \\
174.5 \mathrm{ft}^{3} \\
\text { - Nominal batch volume: } 5,500 \text { gallons (in } \\
\text { cylindrical section of tank) }\end{array}$} & $\begin{array}{l}\text { - } \quad \text { Volume of each head: } 843 \text { gallons } \\
\text { - } \quad \text { Tank I.D. }=11 \text { feet } \\
\text { - } \quad \text { Tangent to tangent length }=10.12 \text { feet } \\
\text { - } \quad \text { Total tank height }=13.69 \text { feet } \\
\quad \text { Drop from top of flange to nominal working } \\
\text { volume }=36.12 \text { inches }\end{array}$ \\
\hline III: & \multicolumn{2}{|c|}{$\begin{array}{l}\text { Sludge, GFC, and melter feed data to determine maximum GFC drop expected for nominal } \\
\text { working/batch volume relative to top of tank. }[15,16,17,18]\end{array}$} \\
\hline \multicolumn{3}{|c|}{ - Input from these reference sources will be used to calculate this maximum drop prior to GFC addition. } \\
\hline IV: & \multicolumn{2}{|c|}{ Air purge rates into vessel and off-gas line size. $[12,19]$} \\
\hline $\begin{array}{ll}\text { - } & \mathrm{H} \\
-\mathrm{H} & \mathrm{H} \\
\end{array}$ & $\begin{array}{l}\text { ubblers }=1 \text { SCFM } \\
{ }_{2} \text { Purge air }=5 \text { SCFM }\end{array}$ & $\begin{array}{l}\text { - } \quad \text { Eductor during nominal operations }=10 \text { SCFM } \\
\text { - Off-gas line }=4 " \text { schedule } 40 .\end{array}$ \\
\hline V: & \multicolumn{2}{|l|}{ Demister [20]. } \\
\hline
\end{tabular}




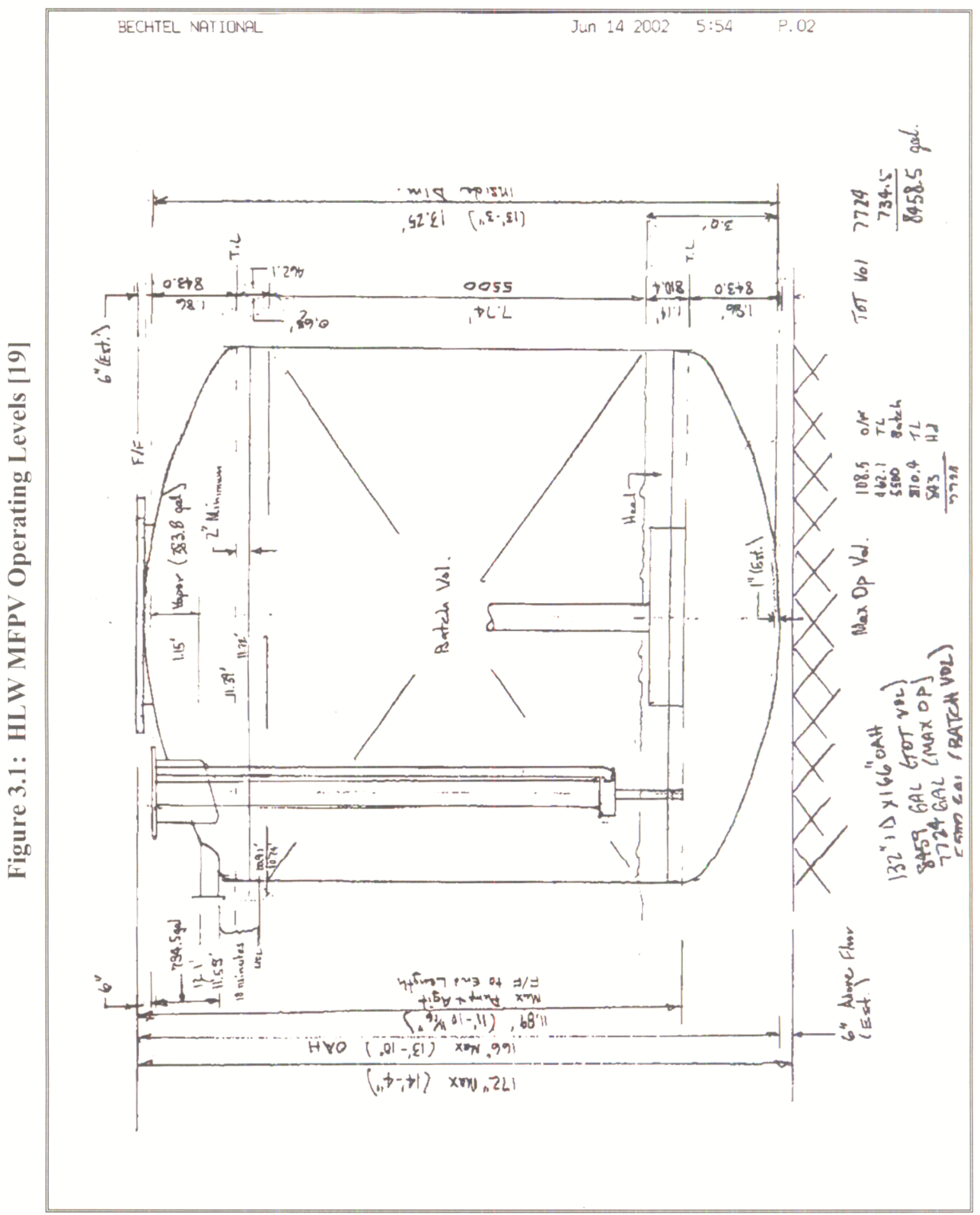


WSRC-TR-2003-00037, REV. 0

SRT-RPP-2003-00006, REV. 0

Figure 3.2: GFC and MFPV Simplified P\&ID

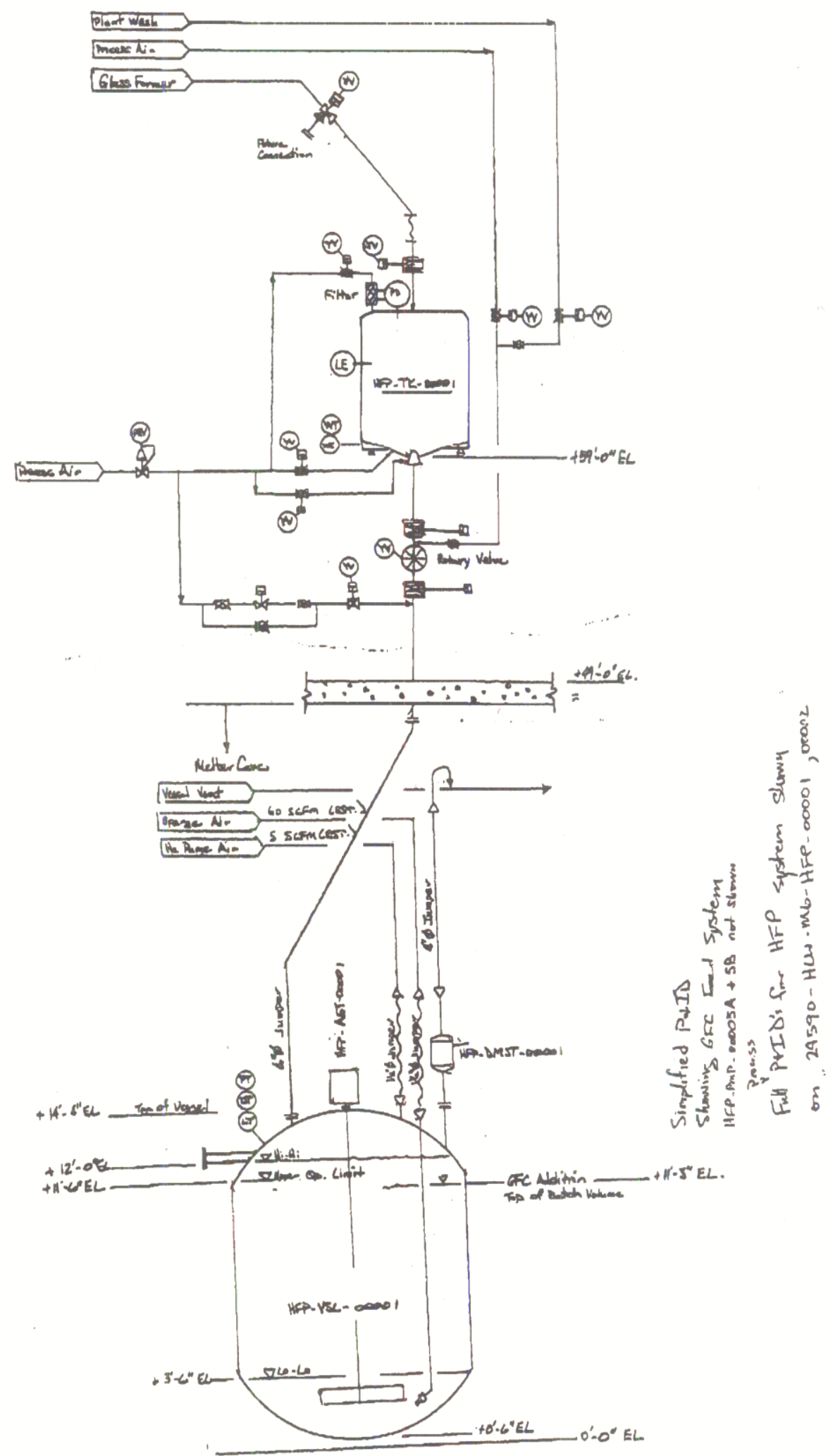


WSRC-TR-2003-00037, REV. 0

SRT-RPP-2003-00006, REV. 0

Figure 3.3: MFPV Tank Top Layout [22]

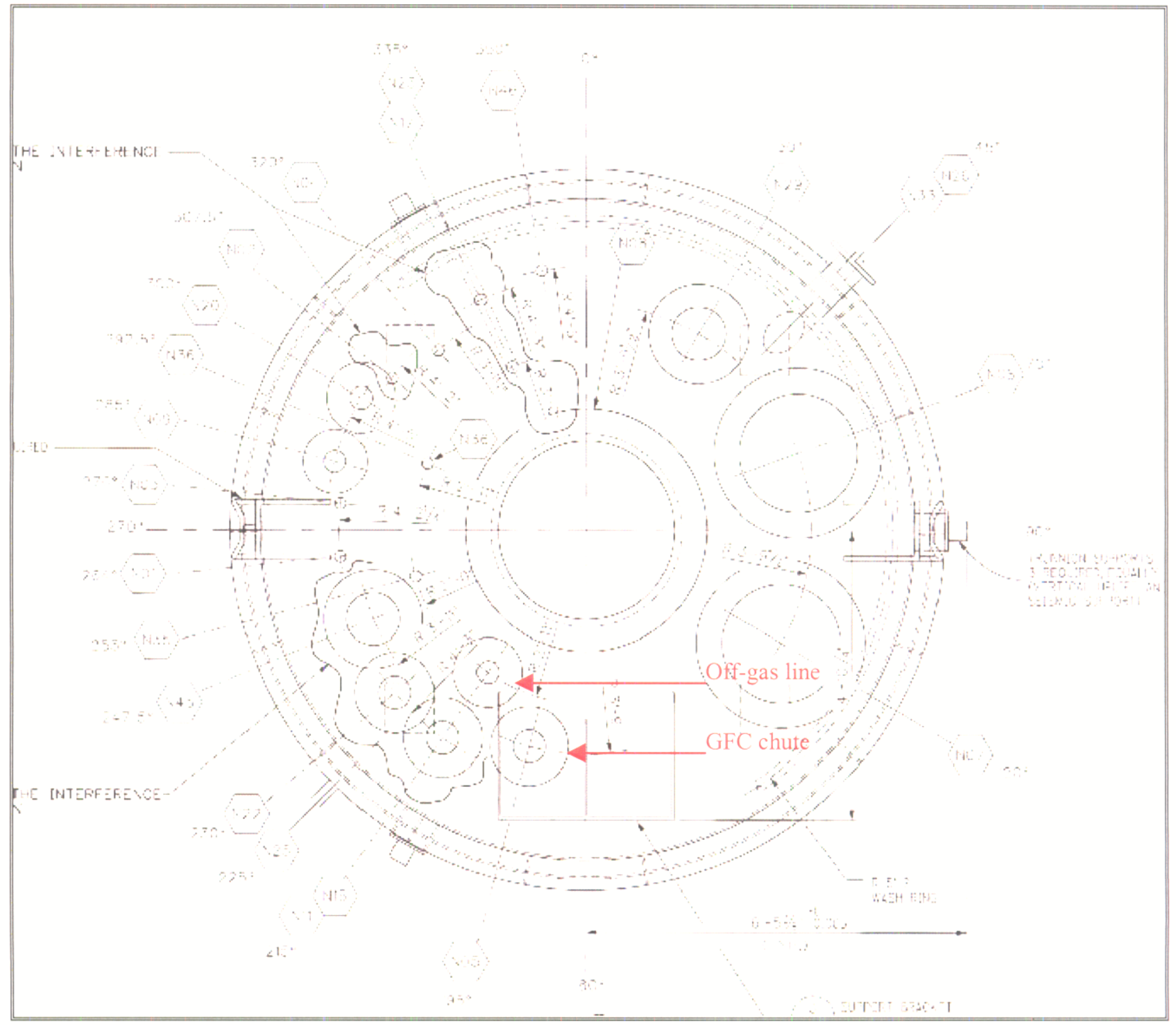

\subsection{PILOT FACILITY SIZI NG}

The following method described in this section was used for sizing the test facility equipment. Sizing of the pilot facility equipment was accomplished by scaling from the preliminary WTP data shown in section 3.3. This data will likely change as the design matures. The scaling parameters used for the pilot facility were included in the Task Technical and QA Plan [ref. 2] which was reviewed and approved by WTP. A dimensional analysis for determining the sizing criteria is included in Appendix A. The nomenclature included in Table 3.2 explains the variables used in each of the following calculations. 
WSRC-TR-2003-00037, REV. 0

SRT-RPP-2003-00006, REV. 0

Table 3.2: Nomenclature of Variables Used In Pilot Facility Calculations

\begin{tabular}{|c|c|c|}
\hline Symbol & Description & Given/Calculated: \\
\hline$\dot{m}_{\text {process }}$ & Mass flow rate of GFC's into MFPV & Table 3.1 item I. \\
\hline$\dot{m}$ pilot & Mass flow rate of GFC's into test vessel. & Calculated in 3.4.4. \\
\hline$\dot{Q}_{\text {process }}$ & $\begin{array}{l}\text { MFPV nominal purge air. Due to unknown air } \\
\text { inleakage at flanged connections, this flowrate will be } \\
\text { used to determine off-gas velocity. }\end{array}$ & $\begin{array}{l}\text { Calculated from information given in Table } \\
3.1 \text { item IV. }\end{array}$ \\
\hline$\dot{Q}_{\text {pilot }}$ & Test vessel purge air. & Calculated in 3.4.2. \\
\hline$\dot{v}_{\text {process }}$ & MFPV nominal off-gas line velocity. & Calculated in 3.4 .3 . \\
\hline$\dot{v}_{\text {pilot }}$ & $\begin{array}{l}\text { Test vessel off-gas velocity to be the same as the } \\
\text { MPPV off-gas line velocity. }\end{array}$ & Calculated in 3.4 .3 . \\
\hline $\mathrm{D}_{\text {process, vessel }}$ & Process MFPV inside tank diameter & Given in 3.3.II. \\
\hline $\mathrm{D}_{\text {pilot, offgas }}$ & Test vessel off gas line inside diameter. & Calculated in 3.4 .3 . \\
\hline $\mathrm{D}_{\text {pilot, vessel }}$ & Scaled inside tank diameter & Stated in 3.4 .2 \\
\hline $\mathrm{D}_{\text {pilot, GFC }}$ & Pipe I.D. diameter of GFC chute going into test vessel. & Calculated in 3.4.4. \\
\hline $\mathrm{h}_{\text {lsudge,process,I }}$ & Height of sludge in MFPV for a given composition & Calculated in 3.4 .1$. \\
\hline $\mathrm{H}_{\text {Batch }}$ & Cylindrical height of one full batch & Calculate in section 3.4.1. \\
\hline $\mathrm{H}_{\text {sludge, process }}$ & Cylindrical height of sludge in batch & Calculate in section 3.4.1. \\
\hline $\mathrm{L}_{\text {nominal }}$ & $\begin{array}{l}\text { Drop from top of flange to nominal working volume in } \\
\text { MFPV }\end{array}$ & Given in Table 3.1 item II. \\
\hline $\mathrm{L}_{\text {process }}$ & $\begin{array}{l}\text { Present HLW MFPV: Nominal initial vertical drop } \\
\text { between the top of the average sludge level and top of } \\
\text { the tank. }\end{array}$ & $\begin{array}{l}\text { Given in Table } 3.1 \text { item II and III. } \\
\text { Calculated in 3.4.1. }\end{array}$ \\
\hline $\mathrm{L}_{\text {pilot }}$ & $\begin{array}{l}\text { Test vessel: Initial vertical drop between top of tank } \\
\text { and liquid level. }\end{array}$ & Calculated in 3.4.1. \\
\hline $\mathrm{M}_{\text {sludge,process }}$ & Mass of sludge* in batch size. & Calculate in section 3.4.1. \\
\hline $\mathrm{M}_{\text {total, ,process }}$ & Mass of melter** feed in batch size & Calculate in section 3.4.1. \\
\hline $\mathrm{R}_{\mathrm{S}-\mathrm{MF}}$ & Ratio of sludge mass to melter feed mass & Provided in references in Table 3.1 item.III \\
\hline $\mathrm{V} / \mathrm{h}$ & Volume per inch in the MFPV cylindrical section. & Calculated in 3.4.1. \\
\hline$V_{\text {batch }}$ & Batch size volume of the MFPV tank & Given in Table 3.1 item .II. \\
\hline $\mathrm{V}_{\text {nominal }}$ & $\begin{array}{l}\text { The vapor space in the MFPV at nominal tank working } \\
\text { volume. }\end{array}$ & Calculated in 3.4.2. \\
\hline$V_{\text {process }}$ & $\begin{array}{l}\text { Average volume of vapor space in MFPV. Taking the } \\
\text { average of the nominal operating vapor space volume } \\
\left(\mathrm{V}_{\text {nominal }}\right) \text { and the vapor space prior to GFC addition. }\end{array}$ & Calculated in 3.4.2. \\
\hline $\mathrm{V}_{\text {pilot }}$ & Average volume of vapor space in the test vessel & Calculated in 3.4.2. \\
\hline $\mathrm{V}_{\text {sludge, batch }}$ & Volume of sludge in batch & Calculate in section 3.4.1. \\
\hline$\rho_{\text {melterfeed }}$ & Density of melter feed & Provided in references in Table 3.1 item III \\
\hline$\rho_{\text {sludge }}$ & Density of sludge & Provided in references in Table 3.1 item III \\
\hline
\end{tabular}

\subsubsection{Average Maximum Drop From GFC Addition To Sludge Level}

The sludge level in the HLW MFPV prior to GFC addition was determined to be $\mathbf{X}$ feet from the top of the tank by knowing:

- the operating conditions of the MFPV (Table 3.1 item II)

- the densities of the sludge and melter feed and the mass ratio of sludge to melter feed (Table 3.1 item III) 
WSRC-TR-2003-00037, REV. 0
SRT-RPP-2003-00006, REV. 0

After the sludge level was determined, the maximum drop in the tank was calculated and used as the basis for scaling the pilot vessel $\left(\mathrm{L}_{\text {scale }}=\mathrm{L}_{\text {process }}\right)$. This drop from the top of the flange to the top of the liquid allows the GFCs to accelerate and expand as they travel through the tank vapor space prior to hitting the liquid surface. This particle velocity was considered an important parameter in dusting. Other influencing parameters that could contribute to dusting, but were not considered, include the following (which may not be all inclusive):

- GFC physical property data and its impact on the process. This test used a single HLW GFC blend approved by RPP-WTP R\&T.

- GFC velocity at discharge of chute (unknown, due to lack of pressure drop calculations and plant design). This is a function of the height and chute design. This test will not determine the velocity of the GFCs leaving the chute and entering into the MFPV vapor space.

- Amount of air used to deliver the GFCs (also called GFC purge air).

- Location and amount of purge air in the tank.

- Air surface motion of the liquid caused by agitation.

- Air velocity profile in the vessel during GFC addition.

Calculation Procedure:

Total Batch Height:

$$
H_{\text {Batch }}=\frac{4 \cdot V_{\text {batch }}}{\pi \cdot D_{\text {process, vessel }}^{2}}
$$

Mass of melter feed in batch volume:

$$
M_{\text {total, } \text { process }}=V_{\text {batch }} \cdot \rho_{\text {melterfeed }}
$$

Mass of sludge in batch volume:

$$
M_{\text {sludge, } \text { process }}=M_{\text {total, } \text { process }} \cdot R_{S-M F}
$$

Volume of sludge in batch volume:

$$
V_{\text {sludge, } \text { process }}=\frac{M_{\text {sludge }, \text { process }}}{\rho_{\text {sludge }}}
$$

Gallons per inch in the cylindrical section:

$$
V / h=\pi \cdot D_{\text {process, vessel }}^{2} \cdot 1-\text { inch }
$$

Displacement of sludge height in the cylindrical section of the tank:

$$
h_{\text {sludge, } \text { process }, i}=\frac{V_{\text {sludge, } \text { process }}}{V / h}
$$

Maximum drop between bottom of flange to top of sludge:

$$
L_{\text {process }, i}=L_{\text {no minal }}+H_{\text {batch }}-h_{\text {sludge, } \text { process }, i}
$$


WSRC-TR-2003-00037, REV. 0

SRT-RPP-2003-00006, REV. 0

Average Maximum drop:

$$
L_{\text {process }}=\frac{1}{n} \sum_{i=1}^{n} L_{\text {process }, i}
$$

Appendix B includes a sample calculation for the VSL AZ-102 NOAHF14 HLW simulant. The results of the various HLW feeds referenced in Table 3.1 item III are shown in Table 3.3, yielding an average maximum drop of 5.11 feet.

Table 3.3: Maximum Drop For Various HLW Blends

\begin{tabular}{||c|c|c|c|}
\hline \multirow{2}{*}{ Maximum drops given reference data in Table 3.1 item III } & \multirow{2}{*}{$\begin{array}{l}\text { Wt. \% solids } \\
\text { sludge }\end{array}$} & \multicolumn{2}{|c|}{ Max Drop $\left(\mathrm{L}_{\text {process }}\right)$} \\
\cline { 3 - 4 } & 27.4 & 68.4 & 5.70 \\
\hline VSL-AZ102 NOAHF14 & 27.4 & 66.3 & 5.52 \\
\hline VSL-AZ102 NOAHF14A & 18.3 & 59.5 & 4.96 \\
\hline VSL-AZ102 NOAHF14A - 18.3 wt. \% - Calculated number & 24.7 & 65.3 & 5.44 \\
\hline VSL-AZ101 NOAHF9 & 24.7 & 65.9 & 5.49 \\
\hline VSL-AZ101 NOAHF11 & 24.7 & 60.6 & 5.05 \\
\hline VSL-AZ101 NOAHF11A & 28.7 & 53.8 & 4.48 \\
\hline VSL-C106/AY102 NOAHF13 & 15 & 56.7 & 4.72 \\
\hline SRTC-AZ102 15 wt. \% & 20 & 58.8 & 4.90 \\
\hline SRTC-AZ102 20 wt. \% & 5 & 52.7 & 4.39 \\
\hline PNNL AZ-102 5 wt. \% & 15 & 67.7 & 5.64 \\
\hline PNNL AZ-102 15 wt. \% & 5 & 49.9 & 4.16 \\
\hline PNNL C-105 5 wt. \% & 15 & 55.6 & 4.64 \\
\hline PNNL C-105 15 wt. \% & 25 & 65.2 & 5.44 \\
\hline PNNL C-105 25 wt. \% & 20 & 60.7 & 5.06 \\
\hline HFP-00003, AZ-101 & 20 & 66.3 & 5.53 \\
\hline HFP-00003, AZ-102 & 20 & 63.1 & 5.26 \\
\hline HFP-00003, AY-102/C-106 & 20 & 62.6 & 5.22 \\
\hline HFP-00003, AY-101/C-104 & 20 & 66.0 & 5.50 \\
\hline HFP-00003, SY-102 & & Min Drop: & 4.16 \\
\hline & & Max Drop: & $\mathbf{5 . 7 0}$ \\
\hline & & Average Drop: & $\mathbf{5 . 1 1}$ \\
\hline
\end{tabular}

\subsubsection{Vapor Space Turnover And Air Purge Rate}

The average vapor space volume was determined by averaging the vapor space volume of the tank at nominal full condition and the vapor space volume with only sludge in the tank. The average volume was used, since the vapor space turnover ratio is a function of the volume of vapor space and the rate at which air was supplied/removed. The turnover ratio would be different for different tank levels. Information provided in Table 3.1 items I and IV were used.

The pilot tank, was constructed of reinforced fiberglass plastic. Its dimensions were based on the required drop determined in 3.4.1. The tank had an inside diameter of $\mathrm{D}_{\text {pilot }}$ of 48 inches and an overall height of 96 inches. 
The average vapor space volume, of the pilot tank was determined by:

$$
\begin{aligned}
V_{\text {pilot }} & =\frac{\pi}{4} \cdot D_{\text {pilot }, \text { vessel }}^{2} \cdot\left(\frac{L_{\text {pilot }}+L_{\text {no min al }}}{2}\right) \\
& =\frac{\pi}{4} \cdot\left(48 \mathrm{in} \cdot \frac{\mathrm{ft}}{12 \mathrm{in.} .}\right)^{2} \cdot\left(\frac{36.12 \mathrm{in} \cdot \frac{\mathrm{ft}}{12 \mathrm{in} .}+5.11 \mathrm{ft}}{2}\right)=51 \mathrm{ft}^{3}
\end{aligned}
$$

The average vapor space volume of the RPP-WTP MFPV was determined by:

$$
\begin{aligned}
V_{\text {process }} & =\frac{V_{\text {no minal }}+\left(\frac{\pi}{4} \cdot D_{\text {process, vesslel }}^{2} \cdot\left(L_{\text {process }}-L_{\text {nomin al }}\right)+V_{\text {no min al }}\right)}{2} \\
& =174.5 \mathrm{ft}^{3}+\frac{\pi}{4} \cdot(11 \mathrm{ft})^{2} \cdot\left(\frac{5.11 \mathrm{ft}-36.12 \mathrm{in} \cdot \frac{\mathrm{ft}}{12 \mathrm{in} .}}{2}\right)=274 \mathrm{ft}^{3}
\end{aligned}
$$

Because the RPP-WTP MFPV has dished ends, the average vapor space volume was not a simple calculation as for $\mathrm{V}_{\text {pilot }}$. By using the MFPV tank diameter and the average drop distance, a larger vapor space volume as compared to the actual MFPV vapor space volume was determined. This would affect the vapor space turn over ratio, hence it would impact the operating parameter of the pilot facility.

Calculate the total air purge rate going into the MFPV:

$$
\dot{Q}_{\text {process }}=(1+10+5) \mathrm{SCFM}=16 \mathrm{SCFM}
$$

Calculate the MFPV vapor space turnover ratio:

$$
\left(\frac{V}{\dot{Q}}\right)_{\text {process }}=\frac{274 \mathrm{ft}^{3}}{16 \frac{\mathrm{ft}^{3}}{\mathrm{~min}}}=17.1 \mathrm{~min}
$$

The vapor space turnover ratios are the same in the pilot and in the process, calculate the purge air into the pilot:

$$
\dot{Q}_{\text {pilot }}=\frac{V_{\text {pilot }}}{\left(\frac{V}{\dot{Q}}\right)_{\text {process }}}=\frac{51 \mathrm{ft}^{3}}{17.1 \mathrm{~min}}=3.0 \mathrm{SCFM}
$$




\subsubsection{Off-Gas Line Sizing}

The intent was that the off-gas line velocity should be maintained in both the MFPV and test vessel, since this provides the motive force in carrying the airborne materials into the off-gas line. Determined the closest commercially available pipe to fit the calculated diameter $D_{\text {scale, }}$ offgas. Rounded up to the nearest commercially available diameter. Information provided in Table 3.1 item I and calculated in section 3.4.2 were used.

Determined the average velocity ( $\left.\dot{v}_{\text {process }}\right)$ in the process off-gas line. It was assumed that the RPP-WTP 4-inch line was a standard schedule 40 pipe:

$$
\dot{v}_{\text {process }}=\frac{\dot{Q}_{\text {process }}}{\frac{\pi}{4} \cdot D_{M F P V, \text { off gas }}^{2}}=\frac{16 \frac{\mathrm{ft}^{3}}{\mathrm{~min}}}{\frac{\pi}{4} \cdot\left(\frac{4.026}{12} \mathrm{ft}\right)^{2}}=181 \frac{\mathrm{ft}}{\mathrm{min}}
$$

Maintain the same off-gas velocity $\left(\dot{v}_{\text {pilot }}=\dot{v}_{\text {process }}\right.$ ) in the pilot vessel and determine the pilot vessel off-gas inside pipe diameter:

$$
D_{\text {pilot, offgas }}=\sqrt{\frac{4 \cdot \dot{Q}_{\text {pilot }}}{\pi \cdot \dot{v}_{\text {pilot }}}}=\sqrt{\frac{4 \cdot 3 \frac{\mathrm{ft}^{3}}{\mathrm{~min}}}{\pi \cdot 181 \frac{\mathrm{ft}}{\mathrm{min}}}}=0.145 \mathrm{ft}=1.74 \text { inches }
$$

The next commercially available transparent PVC pipe size was a 2" schedule 80 , having an inside diameter of 1.939 inches. This increase in pipe diameter reduced the off-gas line velocity to:

$$
\dot{v}_{\text {pilot }, 2^{\prime \prime}, \text { sch } 80}=\dot{v}_{\text {pilot }, 2^{\prime \prime}, \text { sch } 80} \frac{D_{\text {pilot, offgas }}^{2}}{D_{2^{\prime \prime}, \text { sch } 80}^{2}}=181 \frac{\mathrm{ft}}{\mathrm{min}} \cdot\left(\frac{1.74}{1.939}\right)^{2}=145.9 \frac{\mathrm{ft}}{\mathrm{min}} \quad 3.4 .3 .3
$$

Since the off-gas line velocity is critical to the transport of airborne GFCs into the off-gas system, the overall purge rate into the pilot facility was increased to 3.6 SCFM, yielding a calculated pipe diameter of 1.91 inches. This increased the turnover ratio to 14.2 vapor space volumes per minute as compared to 17.1 as calculated in section 3.4.2.

The 3.6 SCFM of purge air was split, based on information provide in Table 3.5 of the actual plant, with 1.2 SCFM going to the vapor space and 2.4 SCFM going to the bubbler system in the pilot facility. 
WSRC-TR-2003-00037, REV. 0

SRT-RPP-2003-00006, REV. 0

\subsubsection{GFC Addition Rate and Chute Size}

The RPP-WTP design mass flow rate of GFC addition ranged from 6000 to $10000 \mathrm{lbm} / \mathrm{hr}$ [Ref. 8 through 11]. SRTC used the nominal value of $8000 \mathrm{lbm} / \mathrm{hr}$, for sizing purposes. Information calculated in section 3.4.2 and provided in Table 3.1 were used to obtain the GFC mass flow rate and chute size.

The rate at which GFCs were added to the pilot facility was determined by conserving the rate at which the GFCs were added to the vapor space.

$$
\frac{\dot{m}_{\text {pilot }}}{V_{\text {pilot }}}=\frac{\dot{m}_{\text {process }}}{V_{\text {process }}}
$$

The targeted mass flow rate to the process was:

$$
\dot{m}_{\text {pilot }}=\frac{8000 \frac{\mathrm{lbm}}{\mathrm{hr}}}{274 \mathrm{ft}^{3}} 51 \mathrm{ft}^{3}=1489 \frac{\mathrm{lbm}}{\mathrm{hr}}
$$

The GFC mass flow rate for commercially available piping was determined such that the $1 / 3$ full rule as recommended by Jenike and Johanson [21] was maintained. The flowrate and pipe size as recommended by a vendor [9] to RPP-WTP was assumed to follow the Jenike and Johanson recommendation. The mass flowrate for other pipe sizes as determined using equation 3.4.4.3 and were summarized in Table 3.4:

$$
\begin{aligned}
& \dot{m}_{\text {pipe }, i}=\rho V \frac{A_{i}}{3}=\frac{\pi}{12} \rho V D_{i}^{2} \\
& V=\frac{12}{\pi \rho} \frac{\dot{m}_{\text {pipe }, i}}{D_{i}^{2}} \alpha \frac{\dot{m}_{\text {pipe }, i}}{D_{i}^{2}} \Rightarrow \frac{\dot{m}_{\text {pipe }, 2}}{D_{2}^{2}}=\frac{\dot{m}_{\text {pipe }, I}}{D_{l}^{2}} \\
& \dot{m}_{\text {pipe }, 2}=\frac{\dot{m}_{\text {pipe }, 1} \cdot D_{2}^{2}}{D_{I}^{2}}
\end{aligned}
$$

Table 3.4: Maximum GFC Flow Rates In Various Sized Piping

\begin{tabular}{|c|c|c|c||}
\hline Pipe (sch 40) & I.D. (inches) & Area $\left(\mathrm{ft}^{2}\right)$ & Maximum mass flowrate $(\mathrm{lbm} / \mathrm{hr})$ \\
\hline 1.5 & 1.61 & 0.01414 & 959.5 \\
\hline $\mathbf{2}$ & $\mathbf{2 . 0 6 7}$ & $\mathbf{0 . 0 2 3 3 0}$ & $\mathbf{1 5 8 1 . 6}$ \\
\hline 4 [ref. 9] & 4.026 & $\mathbf{0 . 0 8 8 4 0}$ & 6000.0 \\
\hline
\end{tabular}

Since the targeted feed rate was $1489 \mathrm{lbm} / \mathrm{hr}$, a 2" pipe was selected. 
WSRC-TR-2003-00037, REV. 0

SRT-RPP-2003-00006, REV. 0

\subsubsection{Summary of Operating Parameters Between the Process and Pilot}

Table 3.2 is the summary of operating parameters comparing the RPP-WTP facility and the CETL pilot facility, based on the information provided at the time the pilot facility was being designed.

Table 3.5: Operating Parameters of RPP-WTP Process and Pilot Facility

\begin{tabular}{|c|c|c|}
\hline Parameter & RPP-WTP Process & Pilot Facility \\
\hline GFC Mass flow rate $(\mathrm{lbm} / \mathrm{hr})$ & $6000-10000$ & 1489 \\
\hline GFC Chute size (inches) & $\begin{array}{c}4 \text { or } 6, \text { sch. } 40, \text { material } \\
\text { unknown }\end{array}$ & $\begin{array}{l}2 \text { sch. } 40 \mathrm{~S} / \mathrm{S} \text { (sloped section) } \\
2 \text { sch. } 80 \text { transparent PVC }\end{array}$ \\
\hline $\begin{array}{l}\text { Drop from discharge of hopper to top of } \\
\text { tank (inches) }\end{array}$ & 536 & 292 \\
\hline Total Tank Volume (gallons) & 8458.5 & 750 \\
\hline Vapor Space Volume $\left(\mathrm{ft}^{3}\right)$ & 274 & 51 \\
\hline $\begin{array}{c}\text { Maximum average GFC drop in Tank } \\
\text { (inches) }\end{array}$ & 61 & 61 \\
\hline $\begin{array}{c}\text { Bubbler purge rate (Bubbler + Eductor) } \\
\text { (SCFM) }\end{array}$ & 11 & 3.6 \\
\hline $\mathrm{H}_{2}$ Purge air (SCFM) & 5 & 1.2 \\
\hline $\begin{array}{c}\text { Off-gas line velocity ( } \mathrm{ft} / \mathrm{min} \text { ) without } \\
\text { GFC purge air }\end{array}$ & 181 & 176 \\
\hline Off-gas Line Size (inches) & 4 sch. 40 & 2 sch. 80 \\
\hline GFC Purge (SCFM) & Unknown & 4.0 \\
\hline Off-gas line filter & Demister & $\begin{array}{l}\text { Cartridge filter - } 0.2 \text { nominal } \\
\text { micron rating }\end{array}$ \\
\hline
\end{tabular}

\subsection{PILOT FACILITY FAB RICATION - INSTALLATION}

Table 3.6 lists the key equipment and instrumentation used in the CETL pilot facility.

The facility layout is presented in Figure 1.1. Two view ports were installed on the sides of the pilot tank a 180 degrees apart and one on the top of the pilot tank. These view ports were sealed using caulk and rubber gasket. The view ports were installed such that they would always be above the slurry level in the tank. The agitator shaft was sealed using three layers of red rubber that had a hole sized slightly smaller than diameter of the agitator shaft. All pipe and tubing penetrations to the tank were sealed with PVC bulkhead fittings.

The agitator speed was controlled using a variable speed drive. The air purge for the bubbler, the tank vapor space, and the GFC chute were controlled using purge air controllers as described in Table 3.6.

The locations of the off-gas line and GFC chute line on top of the pilot tank were located in the same position as shown in Figure 3.3. The radial position for these lines in the pilot facility were determined by taking the radial position in Figure 3.3 and multiplying it by the ratio of the pilot tank diameter to the process tank diameter. The angle between the two was maintained.

The operation of the off-gas system was based on maintaining a differential pressure of zero between the tank vapor space and the environment, by using a control valve and a differential 
pressure gauge that measures the tank vapor space pressure. The purge air that was added to the pilot tank was removed by the off-gas system. If the pilot tank were operated under a vacuum, there would have been a potential for air inleakage that would have increased the off-gas air velocity. The opposite condition would be true if the tank was operated with positive pressure. A small off-gas fan was used to pull the air out of the tank.

Table 3.6: Equipment and Instrumentation Used in Pilot Facility

\begin{tabular}{|c|c|}
\hline Item & Description \\
\hline Tank & $48 "$ I.D., $96 "$ tall reinforced fiberglass tank with a reinforced fiberglass cover \\
\hline Auger & Accurate 600 series feeder \\
\hline Chute & $\begin{array}{l}\text { - 2", sch. 80, transparent PVC piping (did not come in sch. 40) - used in vertical } \\
\text { sections only. } \\
\text { - 2", sch. } 40,304 \mathrm{~S} / \mathrm{S} \text { welded piping. Used in vertical and sloped sections. } \\
\text { - 2" flexible couplings to mate the PVC to } 304 \mathrm{~S} / \mathrm{S} \text {. } \\
\text { - 2" transparent PVC fittings (elbows, tees) } \\
\text { - 2" PVC fitting (caps, tank flange to tube connectors) }\end{array}$ \\
\hline Off-gas & $\begin{array}{l}\text { - 2", sch. 80, transparent PVC piping (did not come in sch. 40) } \\
\text { - 2" transparent PVC fittings (elbows, tees) } \\
\text { - 2" PVC fitting (caps, tank flange to tube connectors) } \\
\text { - 3/4" PVC sch. } 80 \text { pipe and fittings used to reduce 2" line to } 3 / 4 " \text { line } \\
\end{array}$ \\
\hline Off-gas Filter & $\begin{array}{l}\text { Keystone Polypropylene filter 08P-002-10-JE } \\
\quad \text { Nominal } 0.2 \text { micron rating } \\
\quad 41 \frac{1}{2} \text { square feet of filtration area } \\
\text { - Two filter housing to allow for parallel operations. }\end{array}$ \\
\hline $\begin{array}{l}\text { Purge } \\
\text { Controllers }\end{array}$ & $\begin{array}{l}\text { - McMaster Carr air flowmeter with control valve } \\
\$ \quad \text { Catalog number } 41945 \mathrm{~K} 73 \\
\quad \text { Range } 0.4 \text { to } 4 \text { SCFM } \\
\quad \text { Procured } 3 \text {, one for each purge point. }\end{array}$ \\
\hline $\begin{array}{c}\text { Differential } \\
\text { Pressure Gauges }\end{array}$ & $\begin{array}{l}\text { - } \quad-0.5 \text { inch to }+0.5 \text { inch gauge for tank } \\
\text { - } \quad 0 \text { to } 0.5 \text { inch gauge for chute }\end{array}$ \\
\hline Agitator & - Lightnin agitator motor with $101 \times 1$ pitched propeller \\
\hline View Ports & $\begin{array}{l}\text { - Clear } 1 / 8 " \text { " acrylic panel for sides of tank } \\
\text { - Clear } 1 / 2 " \text { Lexan panel for top of tank. }\end{array}$ \\
\hline
\end{tabular}

The sloped section of the GFC chute was fabricated from polished $\mathrm{S} / \mathrm{S}$ tubing. Because of crimping problems that occurred when bending the tubing, the decision [Ref. 4] was made to use commercially available piping. Specialty companies do exist that deal with bending tubing to specified angles, but required up to six weeks of lead time. The sloped section of the GFC chute was made from welded 2", schedule 40, 304 S/S piping. The sloped section had 2.5 feet of piping above and below the 60 degree bends. The sloped selection had a total vertical drop of 4.33 feet and a horizontal run of 2.5 feet, for a total run of 5 feet. The pipe was bent using a hydraulic pipe bender.

The instrumentation used in this task included a differential pressure gauge between the tank vapor space and the environment, an air flow control regulators/indicators, and an off-gas line flow meter. During the second test, a differential pressure gauge was installed upstream of the point where the GFCs were added to the GFC chute. This location was selected, because it provided the pressure at the point where the GFCs were added to the GFC chute and could be used in parallel with the GFC chute purge air, so as to control the rate at which GFC purge air 
was added. The intent was to increase the chute purge air to a point where the pressure between the tank vapor space and GFC addition point was zero as a minimum or slightly positive.

\subsection{PILOT FACILITY PRE PARATION FOR TESTING}

Table 3.7 is the list of GFCs and their weight percent distribution of the HLW blend used in this task. These GFCs are the present baseline GFCs used in all RPP-WTP R\&T activities[5]. The AZ-101 HLW GFC wt. \% distribution was based on Reference 6.

Table 3.7: AZ-101 HLW GFCs Utilization and Blending Composition

\begin{tabular}{|c|c|c|c|c|}
\hline Chemical & Vendor & Name - Grade & $\begin{array}{c}\text { Wt. \% of GFC } \\
\text { in Blend }\end{array}$ & $\begin{array}{c}\text { As-Received } \\
\text { Moisture } \\
\text { Content (wt. } \%)\end{array}$ \\
\hline $\mathrm{Na}_{2} \mathrm{~B}_{4} \mathrm{O}_{7}-10 \mathrm{H}_{2} \mathrm{O}$ & U.S. Borax & 10 Mole Borax - Technical & $32.51 \%$ & $12.02 \%$ \\
\hline $\mathrm{Li}_{2} \mathrm{CO}_{3}$ & Chemettal-Foote & $\begin{array}{c}\text { Lithium Carbonate } \\
\text { Technical, min 99\% }\end{array}$ & $8.88 \%$ & $0.09 \%$ \\
\hline $\mathrm{Na}_{2} \mathrm{CO}_{3}$ & Solvay Mineral & Soda Ash Dense Anhydrous & $9.10 \%$ & $0.80 \%$ \\
\hline $\mathrm{SiO}_{2}$ & U.S. Silica & Silica Sil-Co-Sil 75 & $47.48 \%$ & $0.01 \%$ \\
\hline $\mathrm{ZnO}$ & $\begin{array}{c}\text { Zinc Corporation of } \\
\text { America }\end{array}$ & Zinc Oxide Kadox-920 & $2.02 \%$ & $0.01 \%$ \\
\hline
\end{tabular}

The GFCs were procured by CETL and verified by SRTC. The GFCs were analyzed by CETL for weight percent moisture and those results are listed in Table 3.7. CETL performed the moisture analysis of all the GFCs (except borax) by first weighing out the sample and then placing the sample into a convection oven for two hours at $120^{\circ} \mathrm{C}$. The sample was then removed and placed into a desiccator and allowed to cool to room temperature and the weighed (dry weight). For borax, the sample was placed in a convection oven at $60^{\circ} \mathrm{C}$ for two hours rather than at $120^{\circ} \mathrm{C}$. The moisture content was measured by taking the difference between the mass of the as-received and the mass of the dried sample and dividing this difference by the mass of the dried sample and then multiplying by $100 \%$. Additional information about particle size distribution, mean particle size parameters, chemical composition and other physical data of the individual GFCs used, can be found in Reference 23. SRTC did not make any correction to the GFC batch due to the moisture content reported in Table 3.7.

The GFCs were blended using two different methods. For initial testing purposes, such as checking out the auger and performing functional testing of the pilot facility, two 300 pound batches were blended in 55 gallon drums. The GFCs were added to a clean S/S 55 gallon drum in no particular order and were added in such a manner as too minimize dust generation. A steel chain was then placed into the drum (to help mixing), the drum was closed and placed onto a drum roller (20 revolutions per $\mathrm{min}$ ) for at least two hours. This operation was performed indoors.

The GFCs used for the two pilot tests were mixed in a mechanical tumbler (Figure 3.4), that rotated at $45 \mathrm{rpm}$. The GFCs were added in the order of the easiest flowing (by observation) material first. Borax was added first, then soda ash, silica, lithium carbonate and finally zinc oxide. The dust that was generated by adding the individual bags of GFCs to the mechanical tumbler was allowed to escape openly. Visually, the GFC material that generated the most dust was the Borax and the least dusty was the zinc oxide. The amount of dust generated by the other 
GFCs visually appeared to be somewhere in between borax and zinc oxide. The GFCs were tumbled for approximately 20 minutes and then transferred into 55 gallon S/S drums with plastic liners. During the emptying of the tumbler, the GFCs formed a bridge above the outlet (approximately 14 inches). Rods were then inserted into the outlet of the tumbler to break the bridge. The tumbler has 45 degree carbon steel internal walls and an outlet diameter of 12 inches. The operations of blending the GFCs and transferring them from the tumbler to the 55 gallon drums occurred outside.

Figure 3.4: CETL Mechanical Tumbler

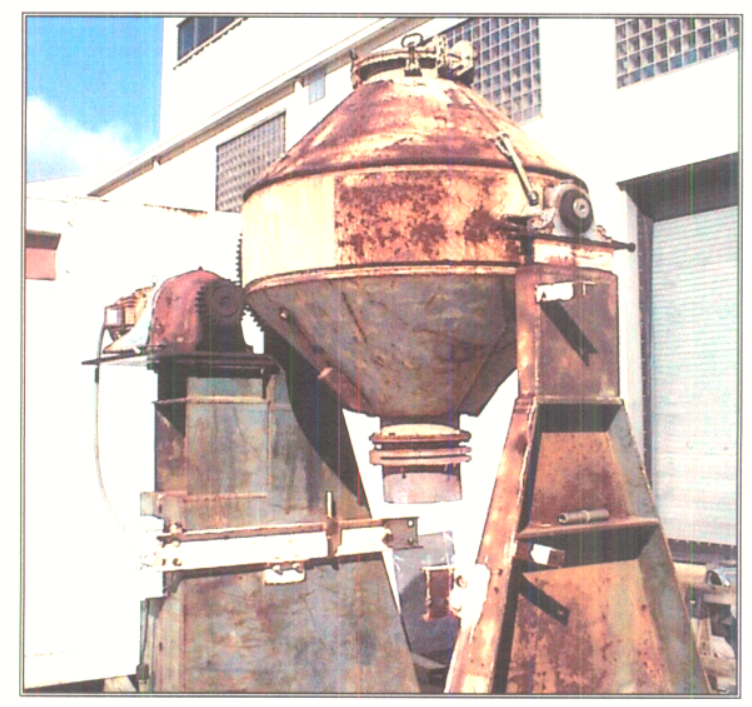

Table 3.8: Batch Makeup of GFCs Used

\begin{tabular}{||c|c|c|c|}
\hline \multirow{2}{*}{ Chemical } & \multicolumn{3}{|c|}{ Batch Makeup of GFCs Used (lbms) } \\
\cline { 2 - 4 } & Functional Checking & $\begin{array}{c}\text { First Run - Drums } \\
\text { Marked 1A \& 2A }\end{array}$ & $\begin{array}{c}\text { Second Run - Drums } \\
\text { Marked 1B \& 2B }\end{array}$ \\
\hline $\mathrm{Na}_{2} \mathrm{~B}_{4} \mathrm{O}_{7}-10 \mathrm{H}_{2} \mathrm{O}$ & 195.1 & 225.6 & 250.4 \\
\hline $\mathrm{Li}_{2} \mathrm{CO}_{3}$ & 53.3 & 61.6 & 68.4 \\
\hline $\mathrm{Na}_{2} \mathrm{CO}_{3}$ & 54.6 & 63.2 & 70.1 \\
\hline $\mathrm{SiO}_{2}$ & 284.9 & 329.5 & 365.6 \\
\hline $\mathrm{ZnO}$ & 12.1 & 14.0 & 15.6 \\
\hline Total & $\mathbf{6 0 0}$ & $\mathbf{6 9 4}$ & $\mathbf{7 7 0}$ \\
\hline
\end{tabular}

\subsection{PILOT FACILITY FUN CTIONAL TESTING}

The GFCs were blended and batched for functional check out of the existing CETL auger and the pilot facility prior to performing the actual tests.

The target mass flow rate for the GFC blend was determined to be $1489 \mathrm{lbm} / \mathrm{hr}$ as stated in section 3.4.4. During functional testing of the existing auger at CETL, it was determined that the obtainable discharge flow rate was only $1430 \mathrm{lbm} / \mathrm{hr}$. Although this rate was below the target rate it was acceptable for the scope of testing to be performed. The cohesive nature of the GFC blend was limiting the rate at which the GFCs could be fed by the auger. Visual inspection of 
WSRC-TR-2003-00037, REV. 0

SRT-RPP-2003-00006, REV. 0

the auger's hopper/spiral section indicated that a bridge was forming and collapsing, thus limiting the mass flow rate.

The loss-in-weight capabilities of the feeder were defeated due to the modifications to the feeder. The GFC addition rate was determined by initially pre-loading the feeder (auger spiral and hopper sections) until the GFCs were level with the top of the hopper section. By knowing the mass of GFCs to be processed, the time of process, and by stopping the auger when the GFCs were level with the top of the hopper section, the average GFC feed rate could be calculated [Ref. 3]:

$$
\dot{m}_{G F C}=\frac{\text { Mass of } \text { GFCs Added }}{\text { Time of Addition }}
$$

The pilot facility was functionally tested after the auger testing was completed. The pilot tank was initially filled with water until the distance between the point where the chute discharged into the tank and the top of the water level in the tank was approximately 60 inches. A plumbing problem was noticed while filling the tank. CETL's hot water system was bleeding into its cold water system, hence the water temperature of the water was greater than the room temperature. This condition created a moist environment during the functional test. The view ports were installed after all the water was added to the tank. Prior to adding the GFCs, 1.2 SCFM and 2.4 SCFM of air were supplied to the tank vapor space and the bubbler respectively. These purge rates were used with and without GFC purge air, during the functional testing of the pilot facility. Approximately one minute after the air was applied to the bubbler, condensation was evident on all the view ports. During the GFC purge air test, 1.8 SCFM was applied to the GFC chute. Approximately one-half of the total blended GFCs volume (as stated in Table 3.8) was reserved for functional testing without purge air and the other half was used for functional testing with purge air. During both tests the differential tank vapor space was maintained as close to zero as possible. The observations noted during these tests are listed in Table 3.9.

The main issues noted during the functional testing of the pilot facility included the GFC addition rate and condensation. A different feed hopper controller was used during this test to drive the motor that was tested earlier. It was assumed that both controllers would provide the same voltage to the motor. The output signal from both controllers was set at $100 \%$ and both controllers were designed to drive the hopper unit. A check of this controller after testing indicated that it was only supplying $85 \%$ of the rated voltage, therefore the original controller was reinstalled and verified to provide the previously reported feed rate.

This testing also revealed that when the auger was loaded as described above, it provided an excellent seal between the GFC chute and environment.

Since the intent of the actual tests was to have a moisture free environment, the water was added to the tank the day before the first test was scheduled to start. All view ports and top tank connections were removed. The water for the second test was stored in a 1000 gallon tank the day before the test, allowing the water to come to thermal equilibrium with the environment. 
WSRC-TR-2003-00037, REV. 0

SRT-RPP-2003-00006, REV. 0

Table 3.9: Observations Noted In Pilot Plant Functional Test

\begin{tabular}{|c|c|c|}
\hline & Without Purge Air & With Purge Air \\
\hline GFC Addition & $\begin{array}{l}\text { No problems noted. Approximately } \\
\qquad 1240 \mathrm{lbm} / \mathrm{hr} \text { added }\end{array}$ & $\begin{array}{l}\text { No problems noted. Approximately } \\
1240 \mathrm{lbm} / \mathrm{hr} \text { added. }\end{array}$ \\
\hline GFC Chute & $\begin{array}{l}\text { Re-circulation of GFCs very evident } \\
\text { in vertical section of transparent } \\
\text { PVC. }\end{array}$ & $\begin{array}{l}\text { Re-circulation of GFCs was not as } \\
\text { noticeable as without purge air. }\end{array}$ \\
\hline Off-gas Filters & $\begin{array}{l}\text { Used one filter bank, but used two } \\
\text { filters during test. Moisture was } \\
\text { evident and is suspect of creating the } \\
\text { high differential pressure across } \\
\text { filter. }\end{array}$ & $\begin{array}{l}\text { Used both filter banks. Same } \\
\text { moisture condition as without purge } \\
\text { air. }\end{array}$ \\
\hline Off-gas Line & \multicolumn{2}{|c|}{$\begin{array}{l}\text { After completion of test, off-gas line was taken apart. Moist GFC were } \\
\text { observed adhering to the off-gas line and were cleaned with water and } \\
\text { allowed to dry. }\end{array}$} \\
\hline Off-gas Fan & \multicolumn{2}{|c|}{$\begin{array}{c}\text { Did not have any problems maintaining the necessary differential pressure in } \\
\text { the tank vapor space and environment. }\end{array}$} \\
\hline Dusting & Very Evident & $\begin{array}{l}\text { Much more evident than without } \\
\text { purge air }\end{array}$ \\
\hline \multirow{3}{*}{ Others } & \multicolumn{2}{|c|}{$\begin{array}{l}\text { Due to condensation of moisture on the tank walls, the GFCs were sticking } \\
\text { to the walls. Wetted surfaces were cleaned using water. }\end{array}$} \\
\hline & \multicolumn{2}{|c|}{$\begin{array}{l}\text { The resulting slurry was allowed to settle and cool over the weekend. This } \\
\text { resulted in crystal formation at the water/air interface, along the tank walls. } \\
\text { The amount of crystals formed was not quantified, but visual observation } \\
\text { noted that at least a gallon of crystals were collected/disposed during the } \\
\text { pump down of the tank. Samples of the crystals were collected. The crystals } \\
\text { were chemically analyzed at SRTC by dissolving the crystals in DI water } \\
\text { and using ICP-ES. The elemental results are shown in Table 3.10. }\end{array}$} \\
\hline & \multicolumn{2}{|c|}{$\begin{array}{l}\text { The S/S section of the chute immediately above the } 1^{\text {st }} \text { elbow had a } \\
\text { accumulation of solids. This material was removed using pressurized air to } \\
\text { blow the material out of the chute and into the tank. }\end{array}$} \\
\hline
\end{tabular}

Table 3.10: Elemental Composition of Collected Crystals from Pilot Facility Functional Testing

\begin{tabular}{|c|c|}
\hline Element & Elemental Weight Percent \\
\hline $\mathrm{B}$ & 11.8 \\
\hline $\mathrm{Li}$ & 0.178 \\
\hline $\mathrm{Na}$ & 11.2 \\
\hline
\end{tabular}

\subsection{PILOT FACILITY FIRS T TEST RESULTS}

Prior to starting the first test, the GFC feeder was filled as described in section 3.7, and the view ports and camera equipment were installed. Cameras were installed on the top and one tank side view port. The tare weight of two off-gas line filters were weighed and installed into the off-gas line filter housing. Only one of the filters was placed in operations. The vapor space purge air (1.2 SCFM) was turned on, the off-gas system adjusted to provide a $\Delta \mathrm{P}$ of zero in the tank vapor 
space and then the bubbler purge air (2.4 SCFM) was turned on and the off-gas system adjusted again to provide a $\Delta \mathrm{P}$ of zero.

Approximately two minutes after the purge air was started, the GFCs were added to the GFC chute. When the GFCs were initially added to the GFC chute, no adjustments were made to the off-gas system. The operating parameters of the first test are shown in Table 1.2. The run plan is located in Appendix C.

During GFC addition, visual observations (and video) were recorded and described in detail in section 1.3.

Only one off-gas line filter was used for the first test, with the mass of GFCs collected in the offgas line and filter as stated in Table 1.3. The weights reported in Table 1.3 were obtained at CETL. During this test, it was noticed that a WTP observer was tapping the off-gas line. This tapping caused some of the GFCs particles clinging to the walls of the off-gas line to fall back into the tank. The observer confirmed that particles were falling back into the tank during tapping. This action reduced the amount of GFCs reported in Table 1.3 from what was actually accumulating in the off-gas line piping. The GFCs in the off-gas line and filter housing (excluding the filter) were collected by disassembling the off-gas system and tapping the piping/housing to free the particles from the lines/filter into a pre-weighed plastic bag. After all the particles were removed from the piping/housing, the plastic bag was weighed. Figure 3.5 shows the locations where GFC particles collected in the off-gas line. There was no evidence of moisture in the off-gas line.

Figure 3.5: GFCs Collected in Off-Gas Line

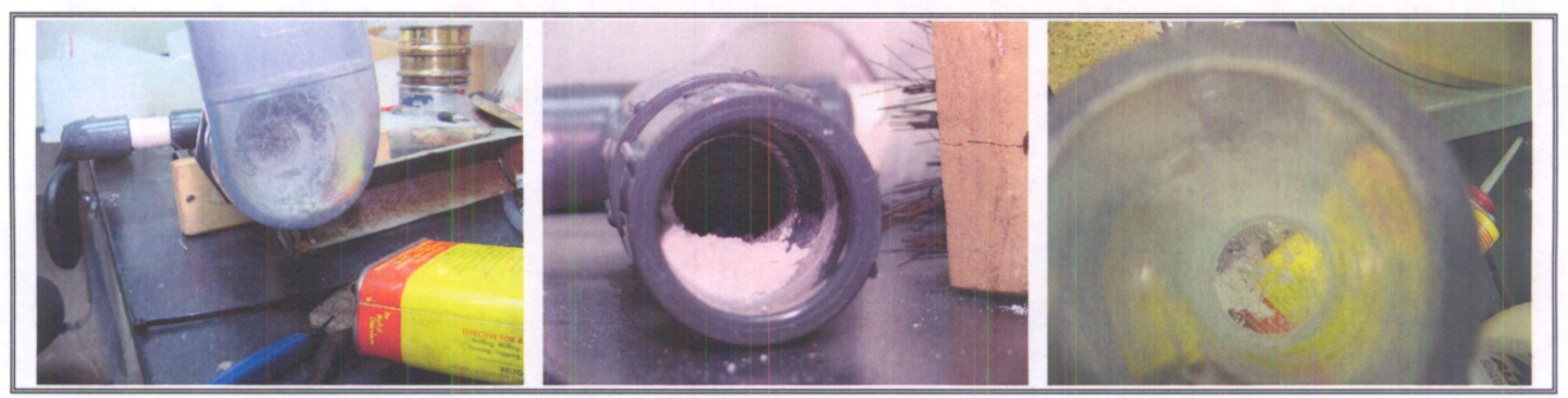

Samples of the GFC particles collected in the off-gas line were analyzed at SRTC for particle size distribution and elemental analysis. There was not enough sample in the off-gas filter to collect for analysis. The off-gas filter is corrugated and has approximately 4.5 square feet of surface area, which captured approximately 0.5 grams of GFCs. The off-gas line particles were analyzed using the MICROTRAC particle size analyzers at SRTC. Two different methods were used to analyze the particle distribution and both methods are described in Table 3.11. The carrier fluid used was DI water. The mean and range for both volume and number analysis are provided in Table 1.3. The MICROTRAC data is located in Appendix D, Figure D.1 through Figure D.4. 
WSRC-TR-2003-00037, REV. 0

SRT-RPP-2003-00006, REV. 0

The off-gas line elemental analysis was performed using ICP-ES. The samples were prepared using $\mathrm{Na}_{2} \mathrm{O}_{2} / \mathrm{NaOH} / \mathrm{HCl}$ and $\mathrm{LiBO}_{2} / \mathrm{HNO}_{3}$ fusion preparation procedures. The elemental weight percent results are shown in Table 1.3.

Table 3.11: SRTC Analysis of Particle Size Distribution

\begin{tabular}{|c|c|}
\hline SRA-150 & X-100 \\
\hline $\begin{array}{l}\text { - } \text { Range } 0.688 \text { to } 704.0 \text { microns } \\
\text { - } \\
\text { - } \text { Requires no refractive index } \\
\text { - } \\
\text { - } \text { Re sonication } \\
\text { - } \\
\text { - } \text { Run time } 30 \text { seconds } \\
\text { Average of } 3 \text { runs reported }\end{array}$ & $\begin{array}{l}\text { - Range } 0.021 \text { to } 704.0 \text { microns } \\
\text { - Assumes particles are: } \\
\text { - Transparent } \\
\text { - Refractive index }=1.81 \\
\text { - No sonication } \\
\text { - Re-circulation flowrate of } 40 \mathrm{ml} / \mathrm{min} \\
\text { - Run time } 30 \text { seconds } \\
\text { - Average of } 3 \text { runs reported }\end{array}$ \\
\hline
\end{tabular}

Visual observations, photographs, and digital video data are described in detail in section 1.3. Figure 3.6 is a still photograph and its negative of the "figure 8" shape described in section 1.3. The material that accumulated on the $\mathrm{S} / \mathrm{S}$ section of piping was not collected for analysis.

Figure 3.6: Figure 8 In S/S Section of Chute in First Run

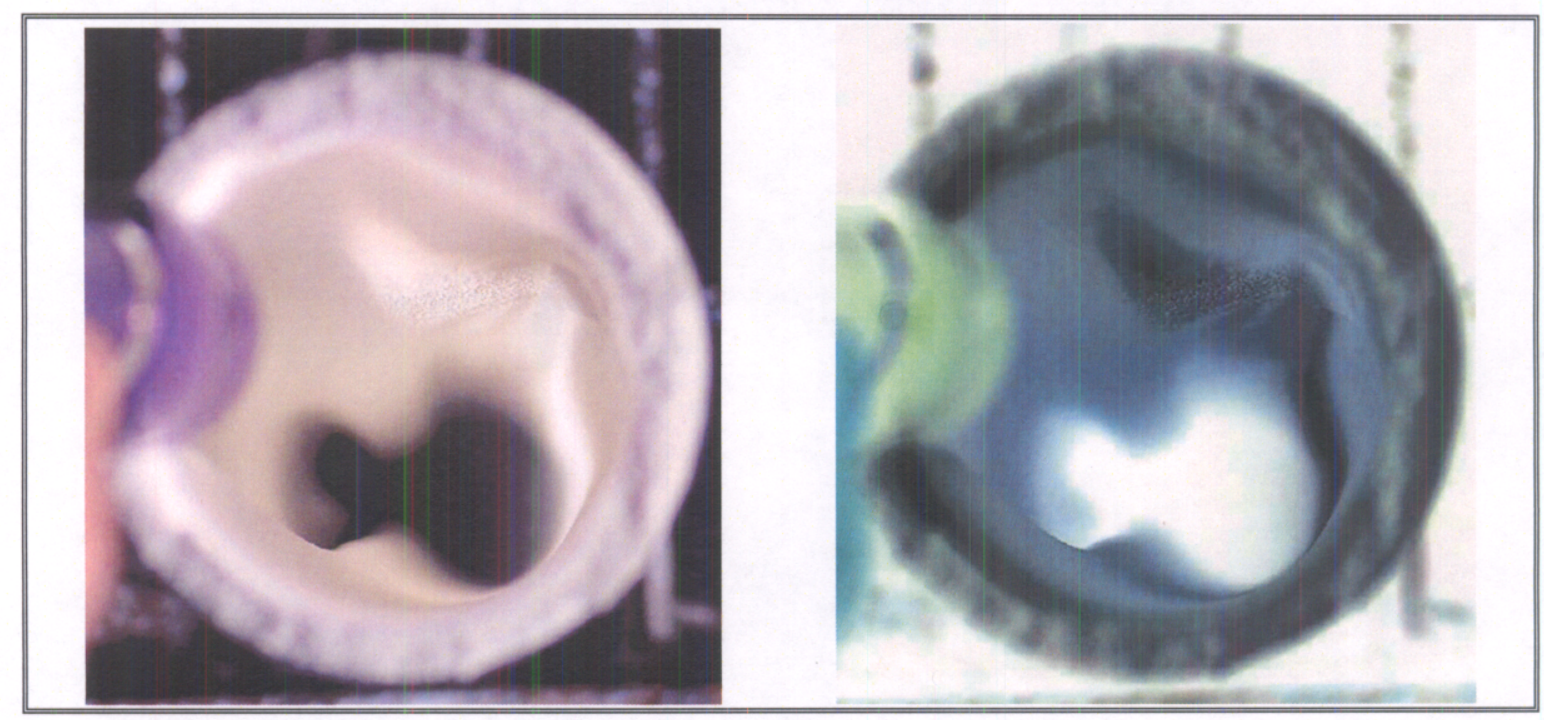

After the inspection of the first run was completed, the GFCs in the chute were blown back into the tank vapor space using conditioned air at CETL. Prior to blowing the GFCs from the chute, the off-gas line was disconnected and a cloth was placed over the discharge of the off-gas line connection at the top of the pilot tank. A shop nozzle (similar to what is used by automotive technicians), was placed at the top of the S/S pipe, covered, and the handle was squeezed several times to remove the accumulated GFCs. These squeezes were in essence small bursts of air. The distance from the nozzle to the buildup was less than 2.5 feet. The CETL air line pressure was 100 psig. After cleaning out the GFCs in the GFC chute, the view ports were removed and cleaned. The inside of the tank was washed using water and the walls of the tank were dried. The contents of the tank were then pump out and the water for the second run was pumped from 
the 1000 gallon tank that was filled the previous day to a level approximately 60 inches from the top of the tank.

\subsection{PILOT FACILITY SECOND TEST RESULTS}

Prior to starting the second test, the results from the first test were discussed in brief detail. The "figure 8" shape that was generated in the first test was an issue, due to the potential for creating a plug over a period of time. It was decided by the observers present (from WTP/DuPont/SRTC) to modify the GFC chute by adding a differential pressure gauge that would measure the pressure between the atmosphere and the top part of the chute immediately upstream of the GFC addition line. The cap upstream of the GFC addition line was removed and a pressure tap was installed. This cap was also tapped for the GFC air purge. The pressure instrument was installed to measure negative pressure and was functionally checked against the differential pressure gauge installed in the tank prior to starting the second run. The range of this gauge from 0 to 0.5 inches of water column.

The GFC feeder did not require any filling, since it was already filled with material from the first run. The view ports and camera equipment were reinstalled. The tare weight of two off-gas line filters were determined and installed into the off-gas line filter housings. Initially, only one of the filters was placed into operations. The vapor space purge air (1.2 SCFM) was turned on, the off-gas system adjusted to provide a $\Delta \mathrm{P}$ of zero in the tank vapor space and then the bubbler purge air (2.4 SCFM) was turned on and the off-gas system adjusted to provide a $\triangle \mathrm{P}$ of zero. After adjusting for the bubbler purge air, the GFCs were then fed into the chute. The GFC purge air was supplied at $1.8 \mathrm{SCFM}$ (as originally planned) and the off-gas system was realigned to run with two filters. The gauge on top of the chute was reading above the 0.5 inches of water column, indicating that a vacuum was present. The GFC purge air was then increased to its maximum of 4 SCFM, but the gauge was still reading above the 0.5 inches of water column. When this occurred, the off-gas system could not handle all of the air inleakage and it was immediately decided that the bubbler purge air should be reduced to compensate for the off-gas system's inability to handle this additional air demand. The bubbler purge air was reduced to 1 SCFM. All of these adjustments took place within a minute after the GFCs were initially fed. The operating parameters of the second test are shown in Table 1.2. The run plan is located in Appendix C.

During GFC addition, visual observations (and video) were noted and described in detail in section 1.3.

Both off-gas line filters were used for this test, with the mass of GFCs collected in the off-gas line and filters reported in Table 1.3. The weights reported in Table 1.3 were obtained at CETL. The GFCs collected in the off-gas line were collected as described in section 3.8. There was no evidence of moisture in the off-gas line. The GFCs collected in the off-gas line showed accumulation of solids as that shown in Figure 3.5.

Samples of the GFC particles collected in the off-gas line and filters were analyzed at SRTC for particle size distribution and elemental analysis. The GFCs collected in the filters were combined. The GFC particles were analyzed using the MICROTRAC particle size analyzers at SRTC. Two different methods were used to analyze the particle distribution and are described in 
WSRC-TR-2003-00037, REV. 0

SRT-RPP-2003-00006, REV. 0

Table 3.11. The carrier fluid used was DI water. The mean and range for both volume and number analysis are provided in Table 1.3. The MICROTRAC data is located in Appendix D, Figure D.5 through Figure D.12.

The particle size distribution and chemical composition results for the GFCs removed from the piping in the first and second tests were essentially the same. There were noticeable differences between the piping and filter results in the second test. The chemical composition for the filter was much higher in zinc oxide and had a lower particle size distribution when compared particle size distribution from the piping material. The reason for this difference may have been due to the manner in which the off-gas system piping was configured. Figure 1.1 shows the off-gas system layout, which starts off as a 2" vertical pipe, the 2" pipe is redirected with a standard elbow into a horizontal plane and then reduced to a $3 / 4$ " pipe which tees off into two $3 / 4$ " pipe that branches into the filters. As the 2 " line is reduced to a $3 / 4$ " line, a 2 " $\times 3 / 4$ " bushing was used. One explanation could be that as the GFCs travel through the piping, the larger particles (a product of density and diameter) have higher impact energies when compared to smaller particles making it harder for these larger particles to negotiate the turns due to their higher momentum. Once these larger particles have collided with the walls (at elbows, tees, and bushings), they adhere to the surface of the piping and to other particles. There was not enough turbulence in the piping to resuspend the particles; hence they do not reach the filters. 


\subsection{REFERENCES}

1. Prindiville, Kerry, "Demonstration of HLW Glass Former Delivery and Blending Proof-ofPrinciple Test", 24590-HLW-TSP-RT-02-007, Rev. 0, 6/5/2002

2. Hansen, Erich, "Demonstration of HLW Glass Former Delivery and Blending Proof-ofPrinciple Test", WSRC-TR-2002-00323, Rev. 0, 8/14/2002

3. Prindiville, Kerry, "Demonstration of HLW Glass Former Delivery and Blending Proof-ofPrinciple Test", Test Exemption number 24590-WTP-TEF-RT-02-067, 9/12/2002

4. Prindiville, Kerry, "Demonstration of HLW Glass Former Delivery and Blending Proof-ofPrinciple Test", Test Exemption number 24590-WTP-TEF-RT-02-080, 11/11/2002

5. Schumacher, R. F., "Selection of HLW and LAW Glass Formers", SRT-RPP-2002-00034, $2 / 6 / 2002$

6. Matlack, K. S., "Test Plan - Integrated DM1200 Melter Testing of HLW AZ-101 Compositions Using Bubblers", VSL-02T8000-1, 5/6/2002.

7. Erich, Donald L., "Quality Assurance Project Plan - Demonstration of HLW Glass Former Delivery and Blending", CETL-02-001, Rev. 0, 7/29/2002

8. Tevis, C. D., Email “Request for Chute Design", 12/4/2001

9. Johnson, P., "Telephone Conversation Record - Glass Former Feed into the Feed Preparation Vessels", CNN-013392, 11/5/1999.

10. Cross, S., Fax of Simplified P\&ID, 6/14/2002.

11. Tevis, C.D., "Subject: Design Process Data for Glass Former Chemical Characterization", CNN-027800, 2/3/2002

12. Cross, S., Fax of Blend Vessel, 6/14/2002.

13. Bogaerts, C., "HLW Melter Feed Preparation Vessel V31101 and Melter Feed Vessel V31102 Sizing", 24590-HLW-MVC-HFP-00001, 10/17/2001.

14. Sinharoy, S., "HLW Melter Feed Preparation Vessel and Melter Feed Vessel Sizing", 24590HLW-M6C-HFP-00001, 2/5/2002.

15. Bogaerts, C., "Oxide Loading in HLW Melter Feed”, 24590-HLW-M4C-HFP-00003, $3 / 1 / 2002$.

16. Bredt, P.R., etc., "Rheological Studies on Pretreated Feed and Melter Feed from C-104 and AZ-102", PNNL-13359, 1/2001

17. Hansen, E. K., etc., "Mixing Envelope D Sludge with LAW Intermediate Products with and without Glass Formers", WSRC-TR-2001-00203, 5/2001.

18. Kot, W.K., etc., "Physical and Rheological Properties of Waste Simulants and Melter Feeds for RPP-WTP HLW Vitrification", VSL-00R2520-1, 10/31/2000.

19. Cross, S., Email "HLW Blend Vessel", 6/19/2002

20. Beary, M., "HLW Melter Feed System - Tank Demister Sizing", CALC-W375HV-PR00044, $6 / 26 / 2000$.

21. Stuart-Dick, D. and Royal, T. A., "Design Principles for Chutes to Handle Bulk Solids", Jenike \& Johanson Technical Paper \#145.

22. "Equipment Assembly HLW Melter Feed Preparation Vessel”, HFP-VSL-00001(Q), Sheet 1 of $4,8 / 14 / 02$

23. Schumacher, Ray F., "Characterization of HLW and Law glass formers - final report - (U)", WSRC-TR-2002-00282, Rev. 0, Has yet to be issued. 
WSRC-TR-2003-00037, REV. 0

SRT-RPP-2003-00006, REV. 0

\section{APPENDIX A: DIMENSIONAL ANALYSIS}




\section{I: Fall from top of tank to surface of mixer.}

The free fall in the vapor space of the tank permits the GFCs to both accelerate and expand. This same analysis would apply to particles falling through air.

Assumptions:

- Initial velocity of GFC is the same (Particle velocity at discharge of chute unknown due to lack of pressure drop calculations, actual plant design and GFC air purge).

- Effects such as tank purge air and vapor space air currents are unknown and do not impact results

- Particles have different masses and densities and do not influence each other.

- Temperature effects on physical parameters are neglected.

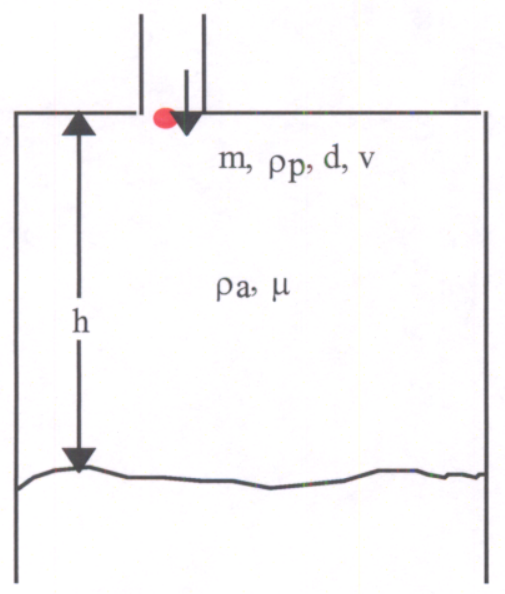

$$
\begin{aligned}
& m=\text { mass of particle } \\
& \rho_{p}=\text { particle density } \\
& \rho_{a}=\text { air density } \\
& d=\text { particle diameter } \\
& h=d r o p \text { in tank } \\
& v=\text { particle velocity } \\
& \mu=\text { viscosity of air }
\end{aligned}
$$

Select the reference variables and the dimensional equations:

\begin{tabular}{|c|c|c|c|}
\hline Variable & Dimension & $\begin{array}{c}\text { Reference } \\
\text { Variables }\end{array}$ & \multicolumn{2}{c|}{$\begin{array}{c}\text { Reference variable } \\
\text { dimensionless equation }\end{array}$} \\
\hline$\rho_{p}$ & $\mathrm{M} / \mathrm{L}^{3}$ & {$\left[\rho_{p}\right]=M / L^{3}$} & $M=\left[\rho_{p} h^{3}\right]$ \\
\hline $\mathrm{H}$ & $\mathrm{L}$ & {$[\mathrm{h}]=\mathrm{L}$} & $\mathrm{L}=[\mathrm{h}]$ \\
\hline $\mathrm{V}$ & $\mathrm{L} / \mathrm{t}$ & {$[\mathrm{v}]=\mathrm{L} / \mathrm{t}$} & $\mathrm{t}=[\mathrm{h} / \mathrm{v}]$ \\
\hline $\mathrm{M}$ & $\mathrm{M}$ & & \\
\hline$\rho_{a}$ & $\mathrm{M} / \mathrm{L}^{3}$ & & \\
\hline $\mathrm{D}$ & $\mathrm{L}$ & & \\
\hline$\mu$ & $\mathrm{M} / \mathrm{L} / \mathrm{t}$ & & \\
\hline
\end{tabular}

Dimensionless equations for the remaining variables:

$$
\begin{aligned}
& {[m]=M=\left\lfloor\rho_{p} h^{3}\right\rfloor} \\
& {\left[\rho_{a} h^{3}\right]=\frac{M}{L^{3}}=\left[\rho_{p} h^{3}\right]} \\
& {[d]=L=[h]} \\
& {[\mu]=\frac{M}{L t}=\left[\frac{\rho_{p} h^{3}}{h \cdot \frac{h}{v}}\right]=\left[\rho_{p} h v\right]}
\end{aligned}
$$


The dimensionless groups are:

$$
\begin{aligned}
& \text { Group 1: } N_{1}=\frac{m}{\rho_{p} h^{3}} \\
& \text { Group 2: } N_{2}=\frac{\rho_{a} h^{3}}{\rho_{p} h^{3}}=\frac{\rho_{a}}{\rho_{p}} \\
& \text { Group 3: } N_{3}=\frac{d}{h} \\
& \text { Group 4: } N_{4}=\frac{\mu}{\rho_{p} h v}
\end{aligned}
$$

Given that particles are the same, from dimensionless groups 1 and 3 , the drop $\mathrm{h}$ is the same in the plant and pilot.

$$
\left(\frac{m}{\rho_{p} h^{3}}\right)_{1}=\left(\frac{m}{\rho_{p} h^{3}}\right)_{2} \Rightarrow \frac{1}{h_{1}}=\frac{1}{h 2} \Rightarrow h_{1}=h_{2}
$$

Dimensionless group 2 states that the air density in both the plant and pilot are the same.

$$
\left(\frac{\rho_{a}}{\rho_{p}}\right)_{1}=\left(\frac{\rho_{a}}{\rho_{p}}\right)_{2} \Rightarrow \rho_{a, 1}=\rho_{a, 2}
$$

Dimensionless group 4 states the ratio of viscosity/velocity is the same in both the plant and pilot.

$$
\left(\frac{\mu}{v}\right)_{1}=\left(\frac{\mu}{v}\right)_{2}
$$


WSRC-TR-2003-00037, REV. 0

SRT-RPP-2003-00006, REV. 0

\section{II: Dust Generation and Dust Density}

Assumptions:

- The mechanism and rate of dust generation are unknown, but are assumed to be the same in both pilot and plant.

- The generation of dust is assumed to be uniform and constant for a given volume of vapor space.

- Listed below are some means of dust generation.

- Some of the particles come into the vapor space as dust.

- By expanding in the vapor space of the tank, dust is stripped from larger particles and becomes airborne.

- The change in momentum when the particle hits the surface of the slurry causes the dust particle to be stripped from the larger particles.

- The air currents in the tank strip the dust from the large particles.

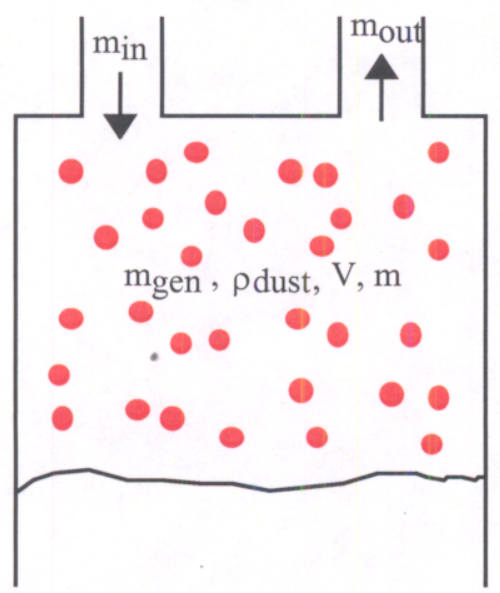

$$
\begin{aligned}
m_{\text {in }} & =\text { mass added per unit time } \\
m_{\text {out }} & =\text { mass removed per unit time } \\
V & =\text { volume of vapor space } \\
m & =\text { mass of dust in vapor space } \\
\rho_{\text {dust }} & =\text { density of dust in vapor space } \\
m_{\text {gen }} & =\text { mass of dust generated per } \\
& \text { unit volume per unit time }
\end{aligned}
$$

Select the reference variables and the dimensional equations:

\begin{tabular}{|c|c|c|c|}
\hline Variable & Dimension & $\begin{array}{c}\text { Reference } \\
\text { Variables }\end{array}$ & $\begin{array}{c}\text { Reference variable dimensionless } \\
\text { equation }\end{array}$ \\
\hline $\mathrm{m}_{\text {in }}$ & $\mathrm{M} / \mathrm{t}$ & {$\left[\mathrm{m}_{\text {in }}\right]=\mathrm{M} / \mathrm{T}$} & $\mathrm{t}=\left[\mathrm{m} / \mathrm{m}_{\text {in }}\right]$ \\
\hline $\mathrm{V}$ & $\mathrm{L}^{3}$ & {$[\mathrm{~V}]=\mathrm{L}^{3}$} & $\mathrm{~L}$ \\
\hline $\mathrm{M}$ & $\mathrm{M}$ & {$[\mathrm{m}]=\mathrm{M}$} & $\mathrm{M}=[\mathrm{m}]$ \\
\hline$\rho_{\text {dust }}$ & $\mathrm{M} / \mathrm{L}^{3}$ & & \\
\hline $\mathrm{m}_{\text {out }}$ & $\mathrm{M} / \mathrm{t}$ & & \\
\hline $\mathrm{m}_{\text {gen }}$ & $\mathrm{M} /\left(\mathrm{L}^{3}-\mathrm{t}\right)$ & & \\
\hline
\end{tabular}

Dimensionless equations for the remaining variables:

$$
\begin{aligned}
& {\left[\rho_{\text {dust }}\right]=\frac{M}{L^{3}}=\left[\frac{m}{V}\right]} \\
& {\left[m_{\text {out }}\right]=\frac{M}{t}=\left[\frac{m}{m / m_{\text {in }}}\right]=\left[m_{\text {in }}\right]} \\
& {\left[m_{\text {gen }}\right]=\frac{M}{L^{3} t}=\left[\frac{m}{V \cdot m / m_{\text {in }}}\right]=\left[\frac{m_{\text {in }}}{V}\right]}
\end{aligned}
$$


The dimensionless groups are:

$$
\begin{aligned}
& \text { Group 1: } N_{1}=\frac{\rho_{\text {dust }} V}{m} \\
& \text { Group 2: } N_{2}=\frac{m_{\text {out }}}{m_{\text {in }}} \\
& \text { Group 3: } N_{3}=\frac{m_{\text {gen }} \cdot V}{m_{\text {in }}}
\end{aligned}
$$

From dimensionless group 2, the rate of mass in and mass out is proportional;

$$
\left(\frac{m_{\text {out }}}{m_{\text {in }}}\right)_{2}=\left(\frac{m_{\text {out }}}{m_{\text {in }}}\right)_{1}
$$

From dimensionless group 3, we get:

$$
\left(\frac{m_{g e n} \cdot V}{m_{i n}}\right)_{2}=\left(\frac{m_{g e n} \cdot V}{m_{\text {in }}}\right)_{1}
$$

Re-arranging:

$$
\frac{m_{g e n, 2}}{m_{g e n, 1}}=\frac{m_{i n, 2} \cdot V_{1}}{m_{i n, 1} \cdot V 2}
$$

From the assumptions made, the generation rate in both the pilot and plant are assumed the same, which results in:

$$
m_{i n, 2}=\frac{m_{i n, 1} \cdot V_{2}}{V_{1}}
$$

Dimensionless group 1 states that:

$$
\left(\frac{\rho_{d u s t} V}{m}\right)_{2}=\left(\frac{\rho_{d u s t} V}{m}\right)_{1}
$$


WSRC-TR-2003-00037, REV. 0

SRT-RPP-2003-00006, REV. 0

\section{III: Vapor Space Turnover}

Assumptions:

- Density is that of air

- GFC do not impact volumetric flow rates

- The vapor space turn over ratios are the same in both the plant and pilot.

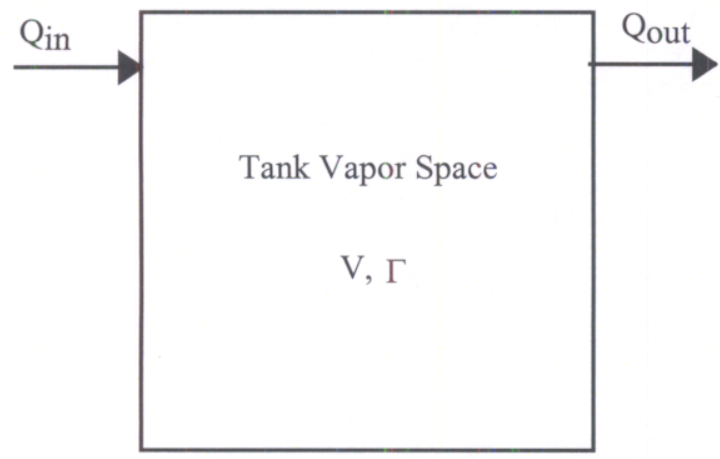

$\mathrm{Q}_{\text {in }}=$ Flow of air in

$\mathrm{Q}_{\text {out }}=$ Flow of air out

$\mathrm{V}=$ Volume of vapor space

$\Gamma=$ number of Vapor Space Volume exchanged per unit time

Select the reference variables and the dimensional equations:

\begin{tabular}{||c|c|c|c||}
\hline Variable & Dimension & $\begin{array}{c}\text { Reference } \\
\text { Variables }\end{array}$ & $\begin{array}{c}\text { Reference variable dimensionless } \\
\text { equation }\end{array}$ \\
\hline$\Gamma$ & $1 / \mathrm{t}$ & {$[\Gamma]=1 / \mathrm{t}$} & $\mathrm{t}=[1 / \Gamma]$ \\
\hline $\mathrm{V}$ & $\mathrm{L}^{3}$ & {$[\mathrm{~V}]=\mathrm{L}^{3}$} & $\mathrm{~L}^{3}=[\mathrm{V}]$ \\
\hline $\mathrm{Q}_{\text {in }}$ & $\mathrm{V} / \mathrm{t}$ & & \\
\hline $\mathrm{Q}_{\text {out }}$ & $\mathrm{V} / \mathrm{t}$ & & \\
\hline
\end{tabular}

Dimensionless equations for the remaining variables:

$$
\left[Q_{\text {in }}\right]=\frac{V}{t}=[V \cdot \Gamma] \text { and }\left[Q_{\text {out }}\right]=\frac{V}{t}=[V \cdot \Gamma]
$$

The dimensionless group is:

$$
N_{1}=\left[\frac{V \cdot \Gamma}{Q_{\text {in }}}\right]
$$

Solving it for the pilot and plant yields:

$$
\left[\frac{V \cdot \Gamma}{Q_{\text {in }}}\right]_{1}=\left[\frac{V \cdot \Gamma}{Q_{\text {in }}}\right]_{2} \text { or } \frac{\Gamma_{1}}{\Gamma_{2}}=\frac{\left[\frac{V}{Q_{\text {in }}}\right]_{2}}{\left[\frac{V}{Q_{\text {in }}}\right]_{1}}
$$

If the rate of the number of vapor space volume turnovers are the same in the plant and pilot, then;

$$
\left[\frac{V}{Q_{i n}}\right]_{1}=\left[\frac{V}{Q_{i n}}\right]_{2} \Rightarrow Q_{i n, 2}=\frac{Q_{i n, 1} V_{2}}{V_{1}}
$$


WSRC-TR-2003-00037, REV. 0

SRT-RPP-2003-00006, REV. 0

\section{IV: Off-Gas Line Velocity}

Assumptions:

- Density is that of air

- GFCs do not impact volumetric flow rates

- GFCs particle size and mass the same in both plant and pilot

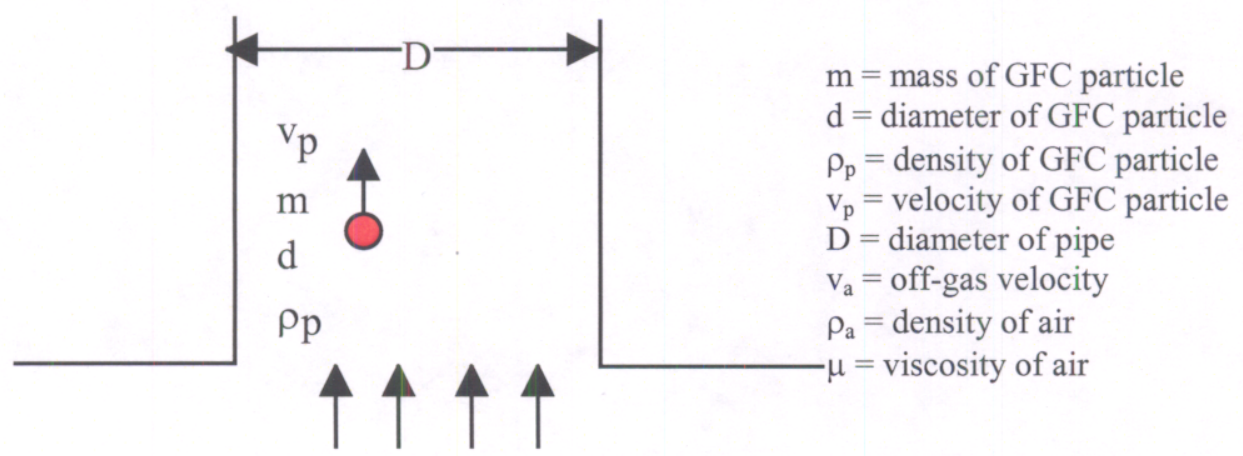

$v_{\mathrm{a}}, \rho_{\mathrm{a}}, \mu$

Select the reference variables and the dimensional equations:

\begin{tabular}{|c|c|c|c|}
\hline Variable & Dimension & $\begin{array}{c}\text { Reference } \\
\text { Variables }\end{array}$ & $\begin{array}{c}\text { Reference } \\
\text { variable } \\
\text { dimensionless } \\
\text { equation }\end{array}$ \\
\hline $\mathrm{m}$ & $\mathrm{M}$ & {$[\mathrm{m}]=\mathrm{M}$} & $\mathrm{M}=[\mathrm{m}]$ \\
\hline $\mathrm{d}$ & $\mathrm{L}$ & {$[\mathrm{d}]=\mathrm{L}$} & $\mathrm{L}=[\mathrm{d}]$ \\
\hline $\mathrm{v}_{\mathrm{a}}$ & $\mathrm{L} / \mathrm{t}$ & {$\left[\mathrm{v}_{\mathrm{a}}\right]=[\mathrm{d}] / \mathrm{t}$} & $\mathrm{t}=\left[\mathrm{d} / \mathrm{v}_{\mathrm{a}}\right]$ \\
\hline$\rho_{\mathrm{p}}$ & $\mathrm{M} / \mathrm{L}^{3}$ & & \\
\hline $\mathrm{D}$ & $\mathrm{L}$ & & \\
\hline $\mathrm{V}_{\mathrm{p}}$ & $\mathrm{L} / \mathrm{t}$ & & \\
\hline$\rho_{\mathrm{a}}$ & $\mathrm{M} / \mathrm{L}^{3}$ & & \\
\hline$\mu$ & $\mathrm{M} / \mathrm{L} / \mathrm{t}$ & & \\
\hline
\end{tabular}

Dimensionless equations for the remaining variables:

$$
\begin{aligned}
& {\left[\rho_{p}\right]=\frac{M}{L^{3}}=\left[\frac{m}{d^{3}}\right]} \\
& {[D]=L=[d]} \\
& {\left[v_{p}\right]=\frac{L}{t}=\left[\frac{d}{d / v_{a}}\right]=\left[v_{a}\right]} \\
& {\left[\rho_{a}\right]=\frac{M}{L^{3}}=\left[\frac{m}{d^{3}}\right]} \\
& {[\mu]=\frac{M}{L t}=\left[\frac{m}{d \cdot d / v_{a}}\right]=\left[\frac{m \cdot v_{a}}{d^{2}}\right]}
\end{aligned}
$$


The dimensionless groups are:

$$
\begin{aligned}
& \text { Group 1: } N_{1}=\frac{\rho_{p} \cdot d^{3}}{m} \\
& \text { Group 2: } N_{2}=\frac{D}{d} \\
& \text { Group 3: } N_{3}=\frac{v_{p}}{v_{a}} \\
& \text { Group 4: } N_{4}=\frac{\rho_{a} \cdot d^{3}}{m} \\
& \text { Group 5: } N_{5}=\frac{\mu \cdot d^{2}}{v_{a} \cdot m}
\end{aligned}
$$

Dimensionless group 1 is not very useful, since the density, mass, and diameter of the particles in both the pilot facility and plant facility are the same.

Dimensionless group 2 states that the diameter of the off-gas line in the plant and pilot facilities are the same, since the same GFCs are being utilized. This is not true.

Dimensionless group 3 states that the velocity of the particle is proportional to the velocity of the air.

$$
\left(\frac{v_{p}}{v_{a}}\right)_{2}=\left(\frac{v_{p}}{v_{a}}\right)_{1}
$$

IV.K

Dimension less group 4 states that air density in both the plant and pilot are the same. In reality, they are fairly close.

Dimensionless group 5 reduces to the following, because the same GFCs are being used in both the plant and pilot facilities

$$
\left(\frac{\mu}{v_{a}}\right)_{2}=\left(\frac{\mu}{v_{a}}\right)_{1} \Rightarrow v_{a, 2}=\frac{v_{a, 1} \cdot \mu_{2}}{\mu_{1}}
$$

Assuming that the plant vapor space is at $50^{\circ} \mathrm{C}$ and pilot is at $20^{\circ} \mathrm{C}$, the viscosities are approximately 0.019 and $0.018 \mathrm{cP}$ respectively, assuming only air. Using a ratio of 1 will yield a conservative value and will be utilized.

$$
v_{a, 2} \approx v_{a, 1}
$$

IV.M 
WSRC-TR-2003-00037, REV. 0

SRT-RPP-2003-00006, REV. 0 
WSRC-TR-2003-00037, REV. 0

SRT-RPP-2003-00006, REV. 0

VSL AZ-102 sim@27.4 wt.\% I.S NOAHF14

Reference Dor VSL-01R3520-1

GIVEN INFO CALCULATED

\begin{tabular}{l|r|ll}
\cline { 2 - 2 } $\mathrm{V}_{\text {batch }}$ & 5500 & gallons & Batch Volume \\
$\mathrm{H}_{\text {batch }}$ & 92.88 & inches & Cylinder height of batch for nominal maximum fill \\
$\mathrm{L}_{\text {nominal }}$ & 45 & inches & Drop from bottom of flange to top nominal maximum fill \\
$\mathrm{V}_{\text {heel }}$ & 1653.4 & gallons & Volume of heel \\
$\mathrm{D}_{\text {process,vessel }}$ & 132 & inches & Inside diameter of tank \\
$\mathrm{V} / \mathrm{h}$ & 59.24 & Gallons/in & Gallons per inch for cyclinder section of tank
\end{tabular}

Determine Mass Of Melter Feed In Batch

wt. \% I.S 27.4 Density(sg) Mass (lbm)

\begin{tabular}{|l|c|c|}
\hline 27.4 & 1.50 & 68819 \\
\hline
\end{tabular}

$M_{\text {total,process }}=V_{\text {batch }} \cdot \rho_{\text {melterfeed }}$

Mass Ratio of Sludge to Melter Feed

wt. \% I.S Ratio

27.4 Ratio

\begin{tabular}{|l|l|}
\hline 27.4 & 0.618 \\
\hline
\end{tabular}

$R_{S-M F}$

Calculated from reference document

Mass of Glass Formers

\begin{tabular}{|c|c|c|}
\hline wt. \% I.S & Mass (lbm) \\
\hline 27.4 & $\mathbf{2 6 2 6 5}$ & $M_{g f c, \text { process }}=M_{\text {total,process }} \cdot\left(1-R_{S-M F}\right)$ \\
\hline
\end{tabular}

Mass/Volume of Sludge to Transfer From Reciept Vessel

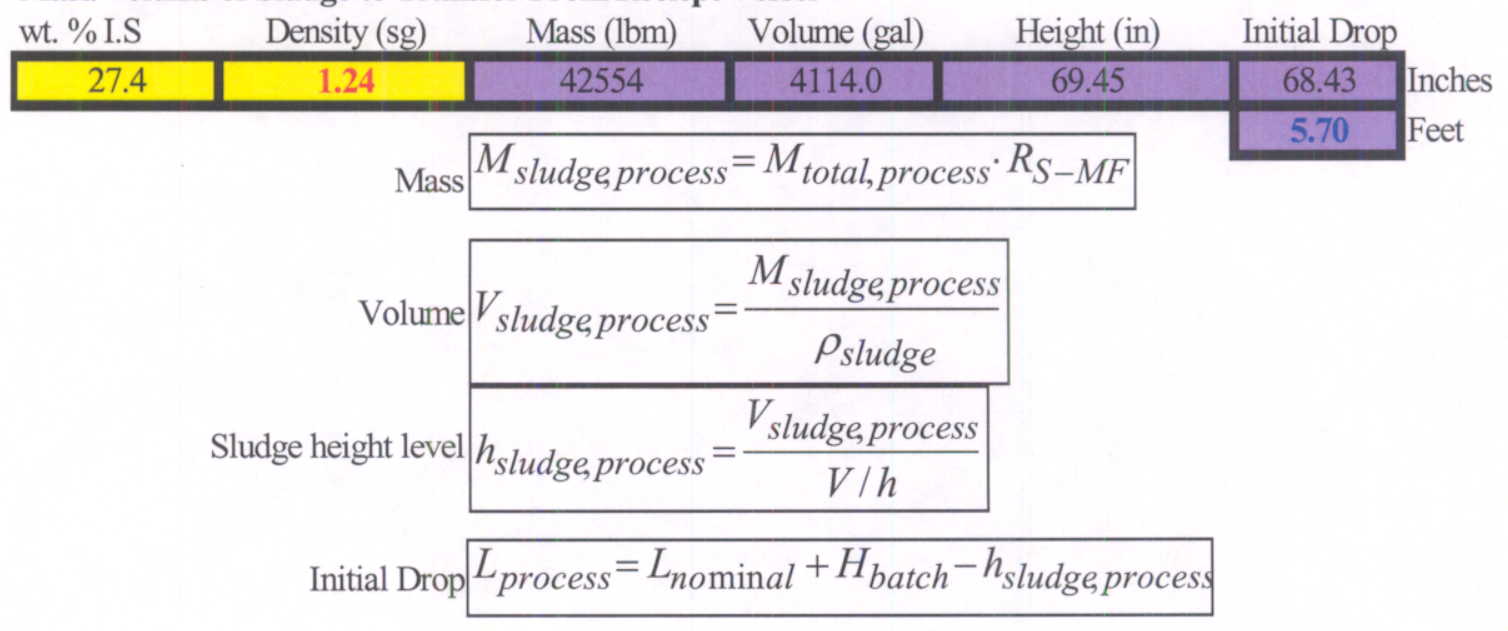


WSRC-TR-2003-00037, REV. 0

SRT-RPP-2003-00006, REV. 0

\section{APPENDIX C: RUN PLAN}


WSRC-TR-2003-00037, REV. 0

SRT-RPP-2003-00006, REV. 0

RUN PLAN:

November 7, 2002

\section{GFC ADDITION TO THE CETL PILOT MIXING VESSEL:}

\section{1: VERIFY THE FOLLOWIING:}

Blended Materials on Hand for the following runs:

Run \#1 without air purge: $\underline{694} \mathrm{lbm}$

Drums are labeled $1 \mathrm{~A}$ and $2 \mathrm{~A}$

Run \#2 air purge: $645 \mathrm{lbm}$

Drums are labeled 1B and 2B

2: VERIFY THE FOLLOWING (check items):

- Off-gas line is connected.

- GFC chute connected to mixing tank.

- Auger connected to GFC chute with 2 SCFM purge air.

- Purge air to vapor space set at 1.2 SCFM.

- Turn on off-gas fan and adjust flow until $\Delta \mathrm{P}$ is zero.

- Install all view ports and install nuts finger tight.

- Light is on in tank.

- Agitator is running with a slight vortex.

3: PERFORM THE FOLLOWING for Run \#1, with no purge air:

- Weigh, record and install filter into holder. If during the run, the $\Delta \mathrm{P}$ cannot be controlled in the tank, swap over filters and removed plugged filter and install a clean filter that has been weighed and recorded.

Filter \#1 clean weight Filter \#2 clean weight 196.31 grams Dirty Weight 196.83 grams Filter \#3 clean weight Dirty Weight Dirty Weight Filter \#4 clean weight GFC's Gathered in the off-gas line: 8.40 grams

- Load the auger using the startup GFCs. Load auger and feed until GFC's are being discharged from the auger. Stop auger and fill with startup GFCs until level with top of hopper.

- Set $1 \mathrm{~A}$ and $2 \mathrm{~A}$ drums next to hopper.

- Turn off purge air at auger connection,

- Set purge air into bubbler at $2.4 \mathrm{SCFM}$; adjust off-gas system to maintain zero $\Delta \mathrm{P}$ in tank.

- Start auger and start the stop watch.

- Feed auger with 1A and 2A drums. Try to maintain level of GFC's level with the top of the hopper.

- Feed all the contents in drums 1A and 2A. Stop the stopwatch and record the time when the level in the hopper is at the top of the hopper, after all the contents in $1 \mathrm{~A}$ and $2 \mathrm{~A}$ have been feed. RECORD TIME 29 minutes

- Notify others that feeding of $1 \mathrm{~A}$ and $2 \mathrm{~A}$ drums are complete.

- Turn off bubbler purge air, install spend air filter and run off-gas through this filter for the remainder of the run.

- Operate auger until all the feed materials are depleted from auger. 
4: CLEANING SEQUENCE AFTER Run \#1 (Photos should be taken, if possible)

- Remove off-gas system and record any findings.

- Remove slip on GFC chute on $2^{\text {nd }}$ level and determine if air purge is required to remove accumulated solids. (note, temporarily reinstall off-gas line if flushing is required)

- Remove and clean all view ports and install temporary lighting

- Pump out contents and wash down walls.

- Transfer water into the mix tank for the next run.

- Dry off interior wall near view ports.

- Inspect chute. Noticed a figure 8 type solids buildup of dry glass former chemicals upstream of the elbow.

5: VERIFY THE FOLLOWING (check items):

- Off-gas line is connected.

- $\quad$ GFC chute connected to mixing tank.

- Auger connected to GFC chute with 2 SCFM purge air.

- Purge air to vapor space set at 1.2 SCFM.

- Turn on off-gas fan and adjust flow until $\Delta \mathrm{P}$ is zero.

- Install all view ports and install nuts finger tight.

- Light is on in tank.

- Agitator is running with a slight vortex.

- Add a differential pressure gauge on top of chute to measure vacuum. Gauge with be used with chute air purge to try and obtain a zero differential between the discharge of the auger to tank vapor space.

6: PERFORM THE FOLLOWING for Run \#2, with 2 SCFM purge air in chute.

- Weigh, record and install filter into holder. If during the run, the $\Delta \mathrm{P}$ cannot be controlled in the tank, swap over filters and removed plugged filter and install a clean filter that has been weighed and recorded.

Filter \#1 clean weight _ 196.87 grams _ Dirty Weight 199.66 grams

Filter \#2 clean weight__196.83 grams Dirty Weight_200.07 grams

Filter \#3 clean weight __ Dirty Weight

Filter \#4 clean weight___ Dirty Weight

GFC's Gathered in the off-gas line: 17.36 grams

- Load the auger using the startup GFC's. Load auger and feed until GFC's are being discharged from the auger. Stop auger and fill with startup GFC's until level with top of hopper.

- $\quad$ Set 1B and 2B drums next to hopper.

- Set purge air into bubbler a 2.4 SCFM; adjust off-gas system to maintain zero $\Delta \mathrm{P}$ in tank. During

- Start auger and start the stop watch.

- Feed auger with 1A and 2A drums. Try to maintain level of GFC's level with the top of the hopper.

- During the evolution of trying to minimize $\Delta \mathrm{P}$ between discharge of the auger and tank vapor space, the chute purge rate went to 4 SCFM (maximum gauge would read), with the differential gauge pegged at 0.5 " of water. During this evolution, the purge air to the bubbler was reduced to 1.0 SCFM. This correction was to allow for maintain an air balance in the tank.

- Feed all the contents in drums 1A and 2A. Stop the stopwatch and record the time when the level in the hopper is at the top of the hopper, after all the contents in $1 \mathrm{~A}$ and $2 \mathrm{~A}$ have been feed.

RECORD TIME 27 minute, 13 seconds.

- Notify others that feeding of $1 \mathrm{~A}$ and $2 \mathrm{~A}$ drums are complete.

- Turn off bubbler purge air, install spend air filter and run off-gas through this filter for the remainder of the run.

- Operate auger until all the feed materials are depleted from auger. 
7: CLEANING SEQUENCE AFTER Run \#1 (Photos should be taken, if possible)

- Remove off-gas system and record any findings.

- Remove slip on GFC chute on $2^{\text {nd }}$ level and determine if air purge is required to remove accumulated solids. (note, temporarily reinstall off-gas line if flushing is required)

- Remove and clean all view ports and install temporary lighting

- Pump out contents and wash down walls.

- Transfer water into the mix tank for the next run.

- Dry off interior wall near view ports.

- Inspect chute. 
WSRC-TR-2003-00037, REV. 0

SRT-RPP-2003-00006, REV. 0

\section{APPENDIX D: PARTICLE SIZE DISTRIBUTION}


WSRC-TR-2003-00037, REV. 0

SRT-RPP-2003-00006, REV. 0

Figure D.1: SRA150 Volume Particle Size Distribution First Run Piping

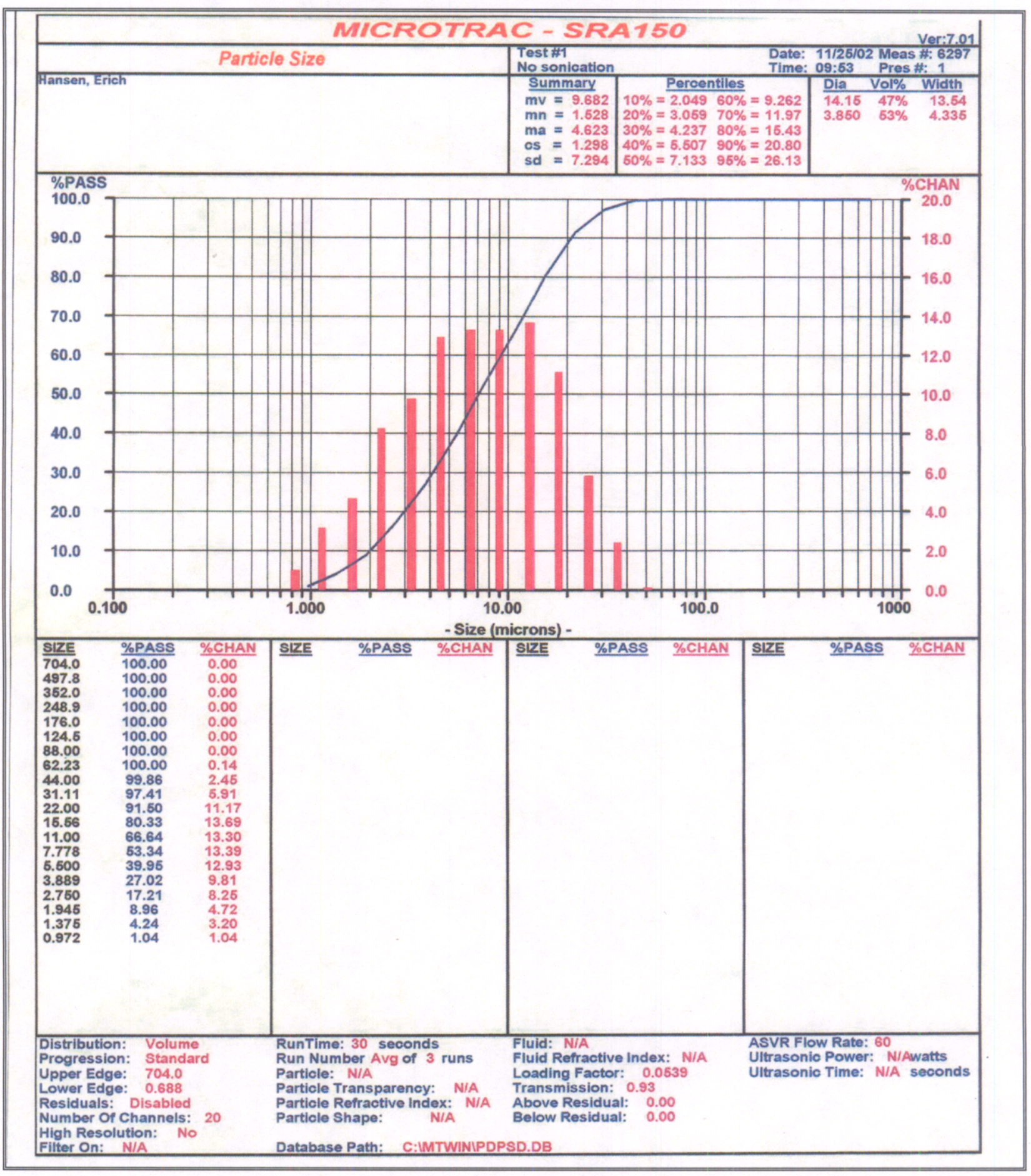

Page 49 of 60 
WSRC-TR-2003-00037, REV. 0

SRT-RPP-2003-00006, REV. 0

Figure D.2: SRA150 Number Particle Size Distribution First Run Piping

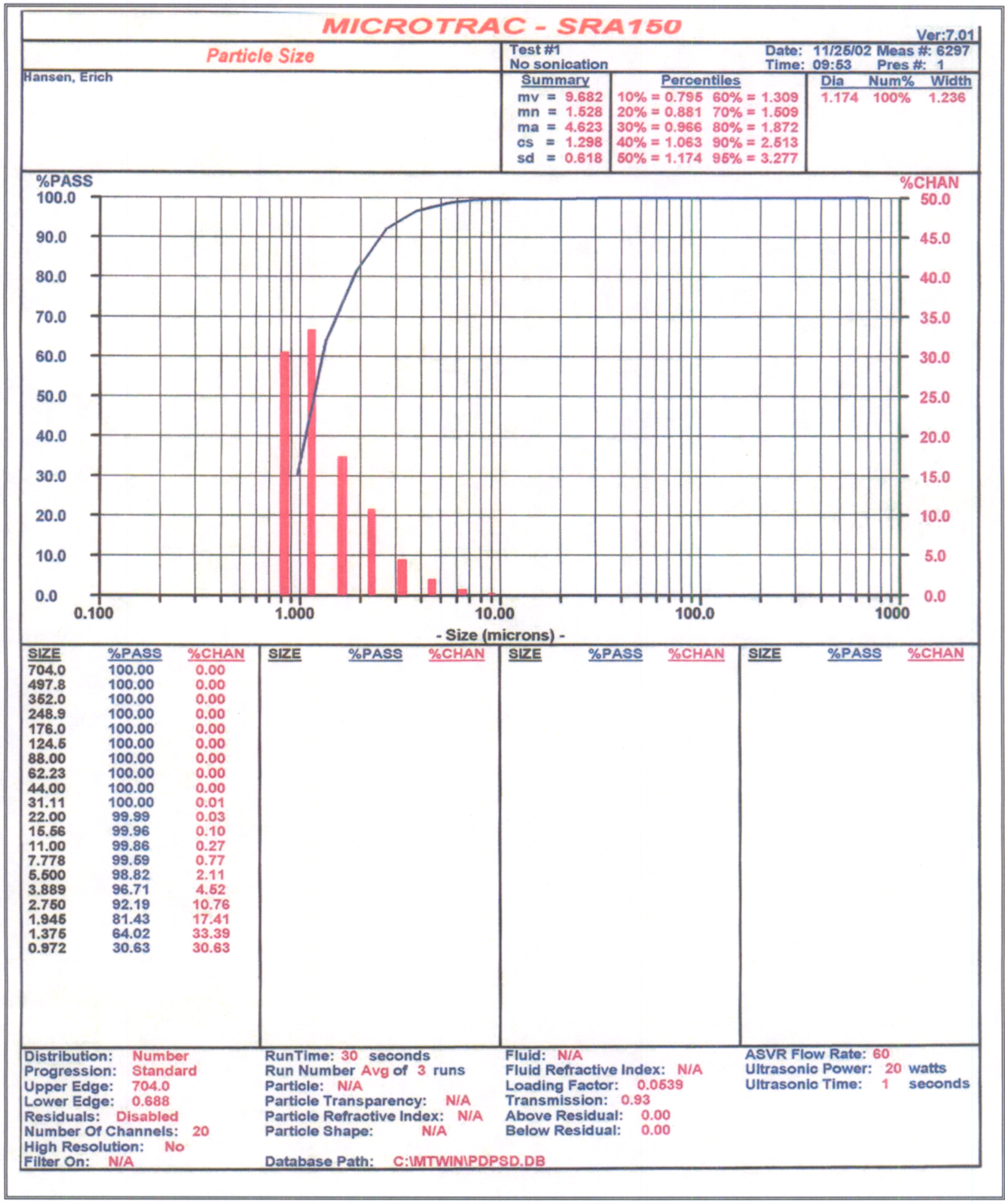


WSRC-TR-2003-00037, REV. 0

SRT-RPP-2003-00006, REV. 0

Figure D.3: X100 Volume Particle Size Distribution First Run Piping

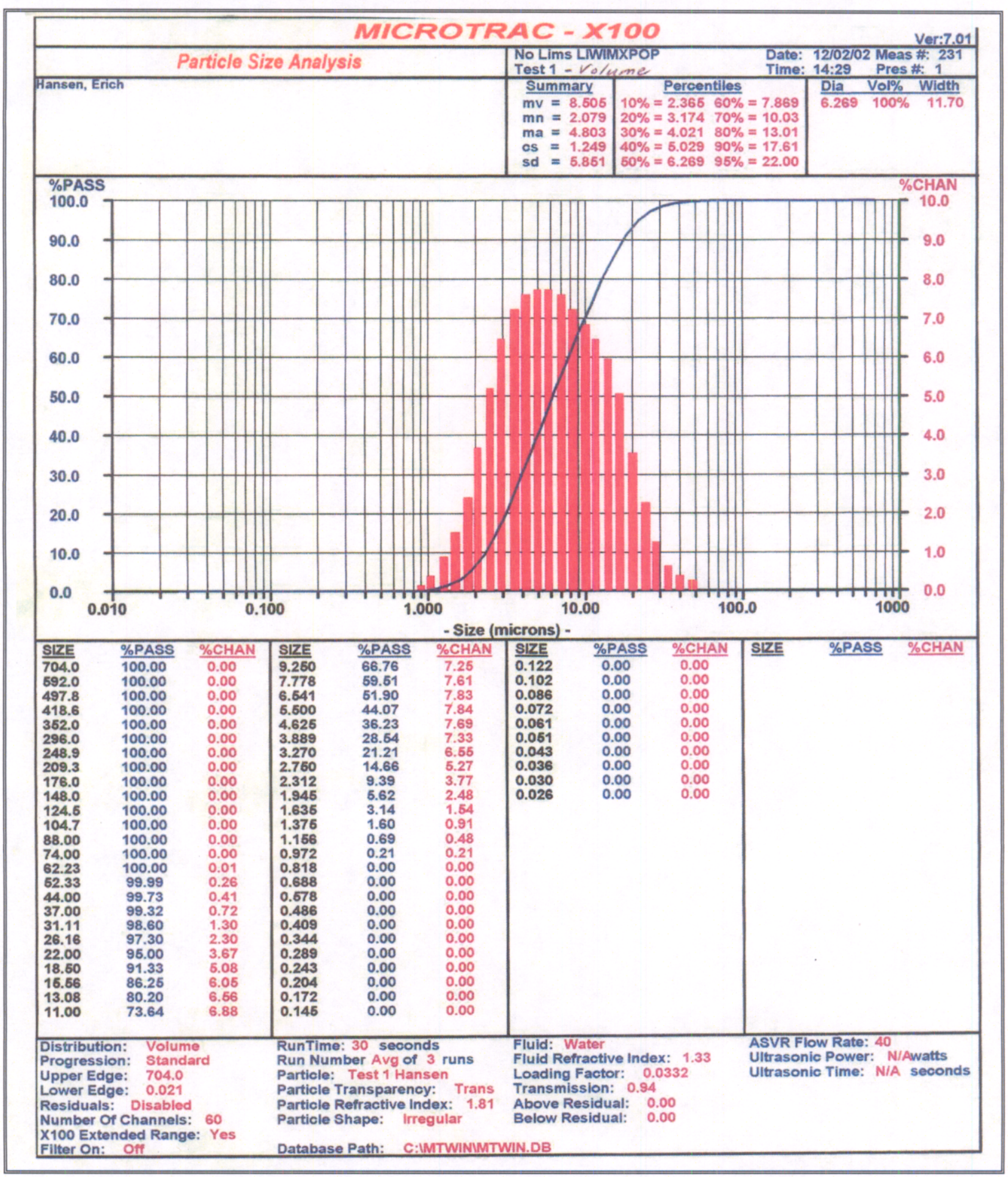


WSRC-TR-2003-00037, REV. 0

SRT-RPP-2003-00006, REV. 0

Figure D.4: X100 Number Particle Size Distribution First Run Piping

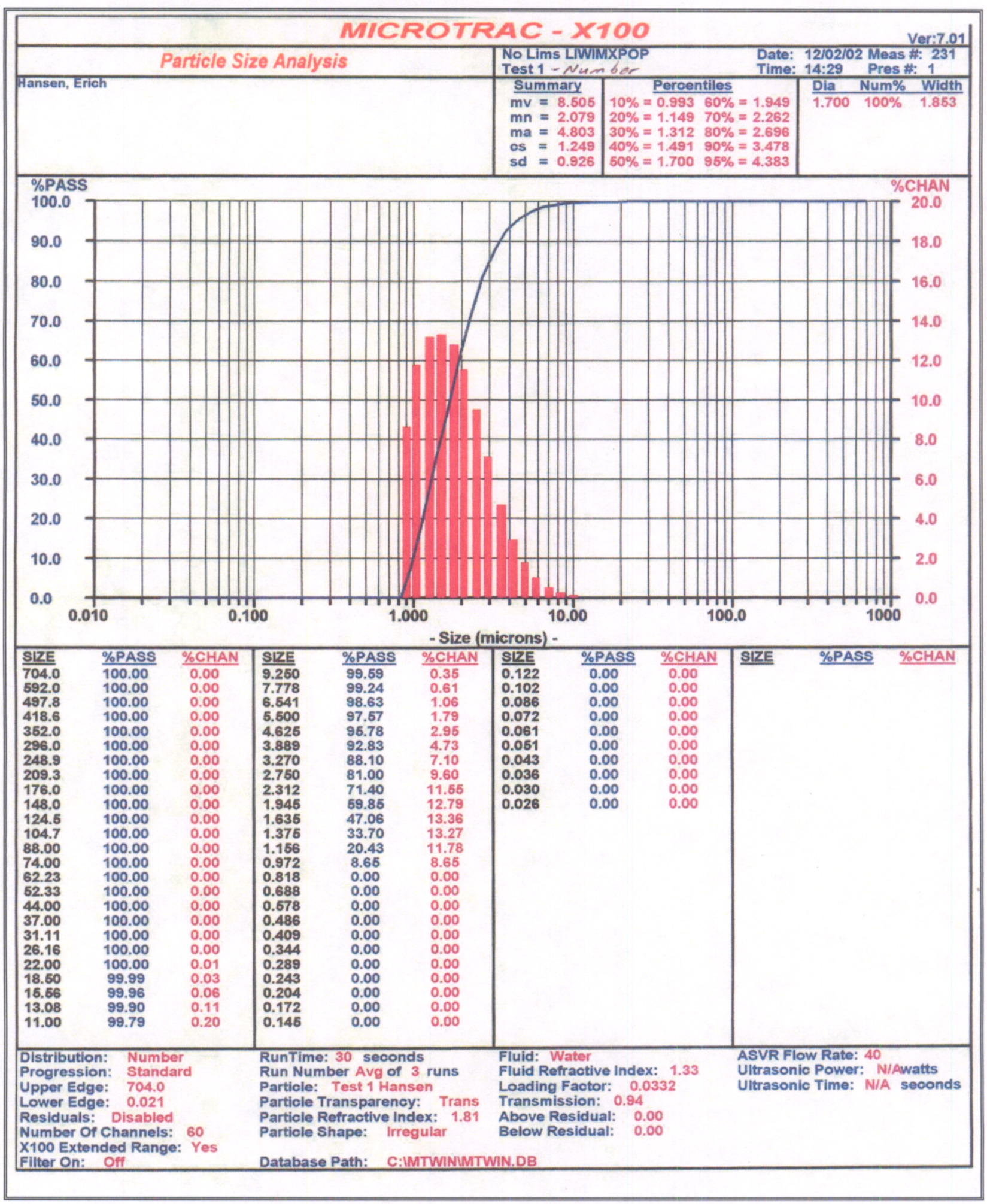


WSRC-TR-2003-00037, REV. 0

SRT-RPP-2003-00006, REV. 0

Figure D.5: SRA150 Volume Particle Size Distribution Second Run Piping

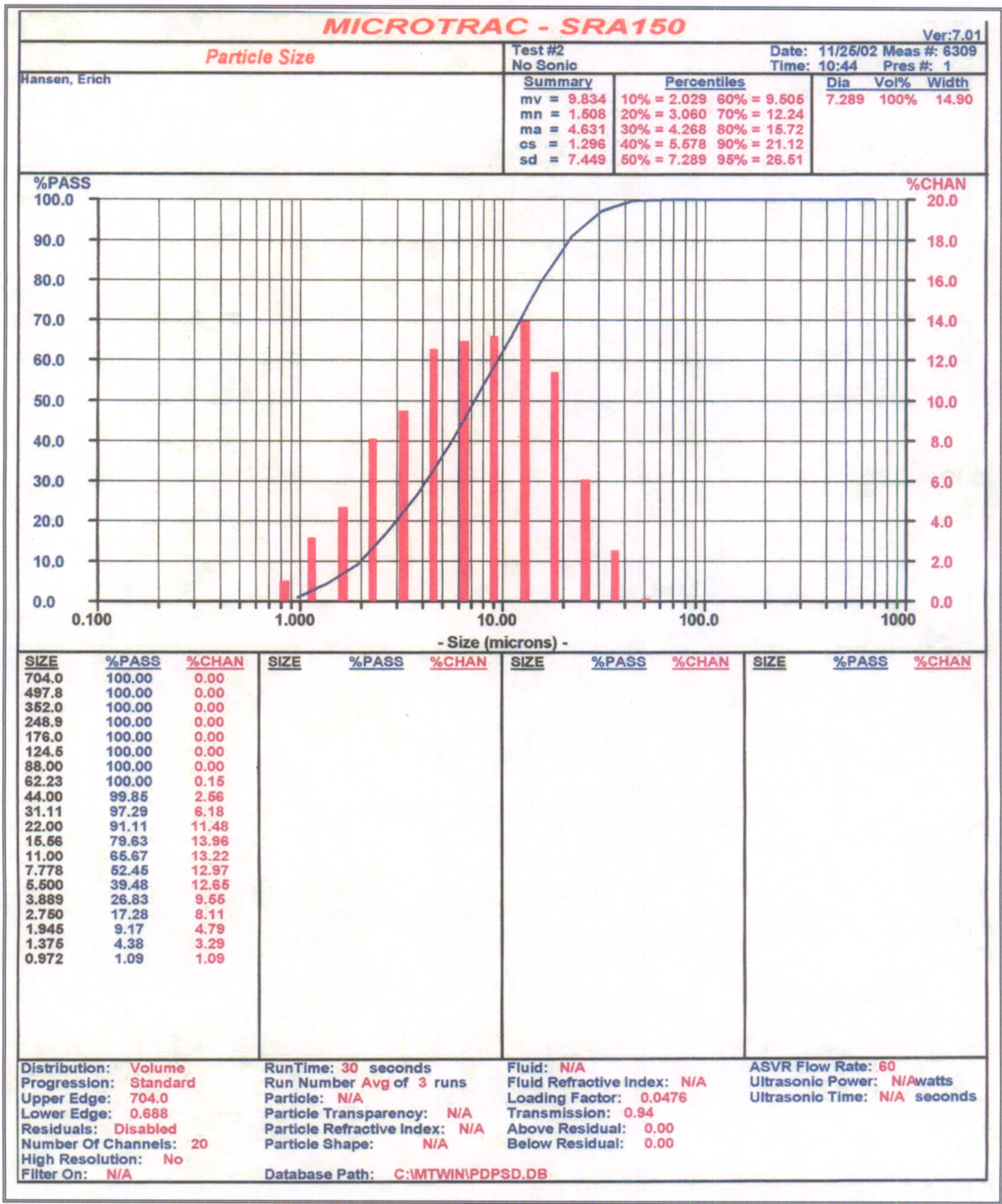


WSRC-TR-2003-00037, REV. 0

SRT-RPP-2003-00006, REV. 0

Figure D.6: SRA150 Number Particle Size Distribution Second Run Piping

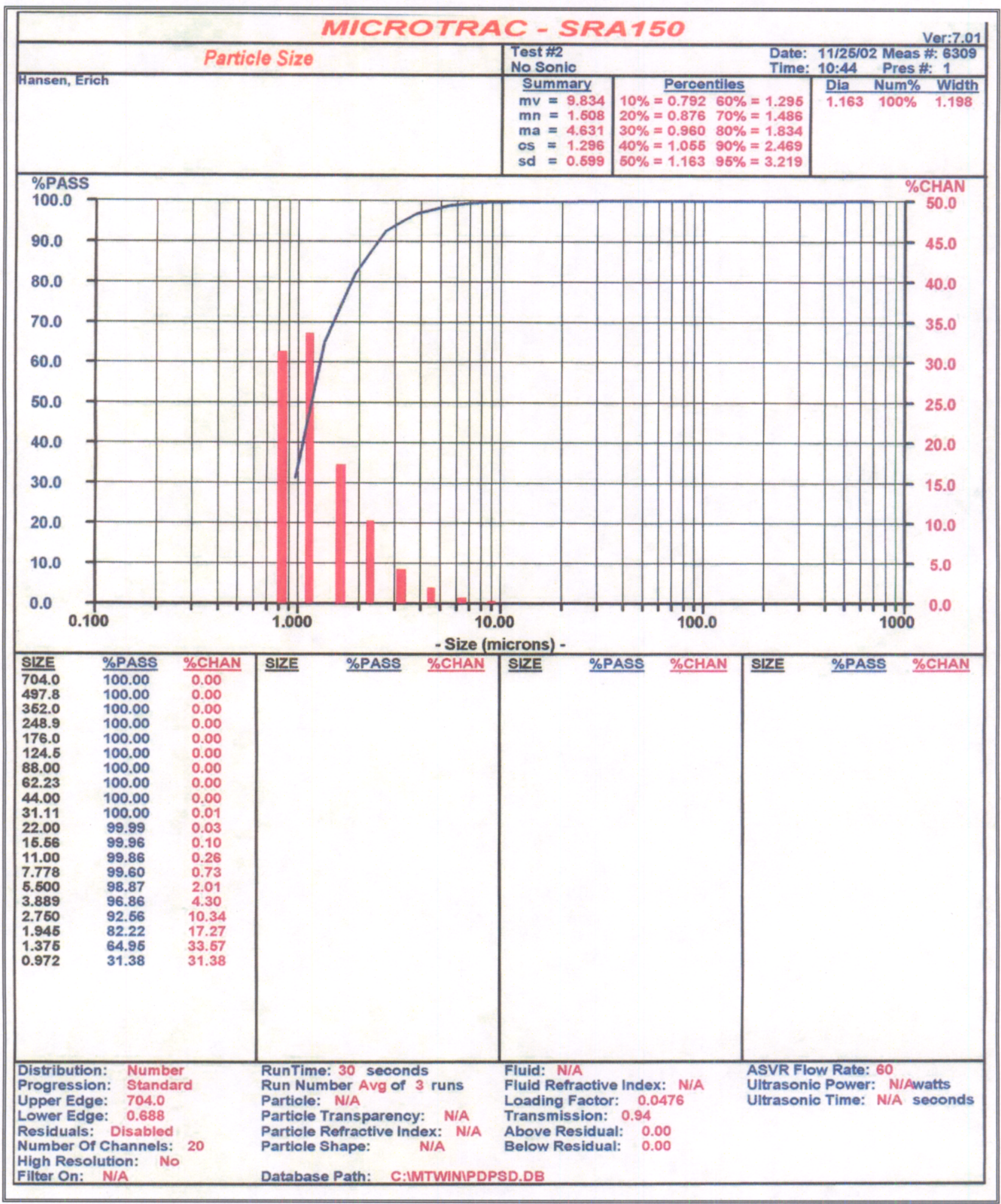


WSRC-TR-2003-00037, REV. 0

SRT-RPP-2003-00006, REV. 0

Figure D.7: X100 Volume Particle Size Distribution Second Run Piping

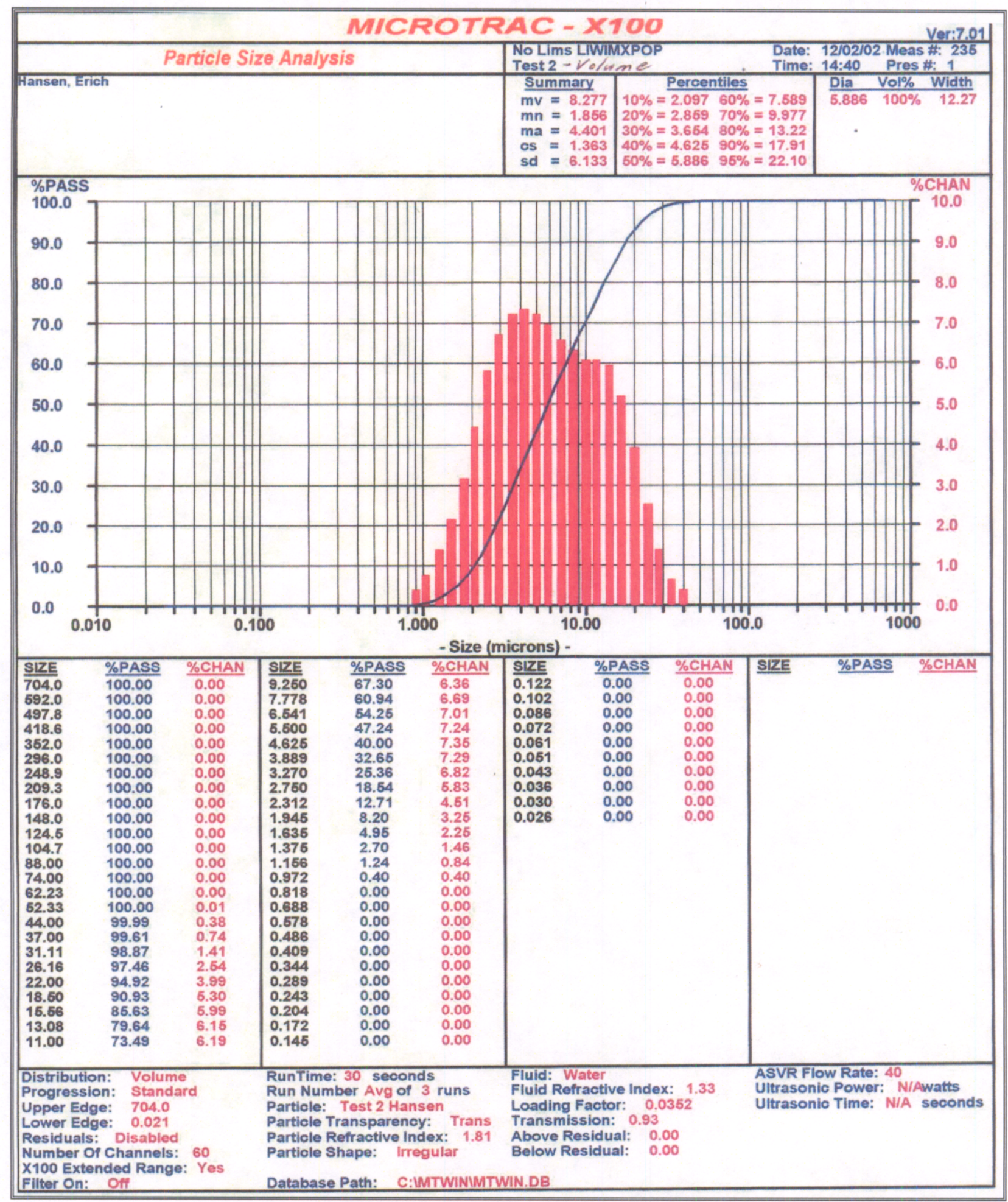


WSRC-TR-2003-00037, REV. 0

SRT-RPP-2003-00006, REV. 0

Figure D.8: X100 Number Particle Size Distribution Second Run Piping

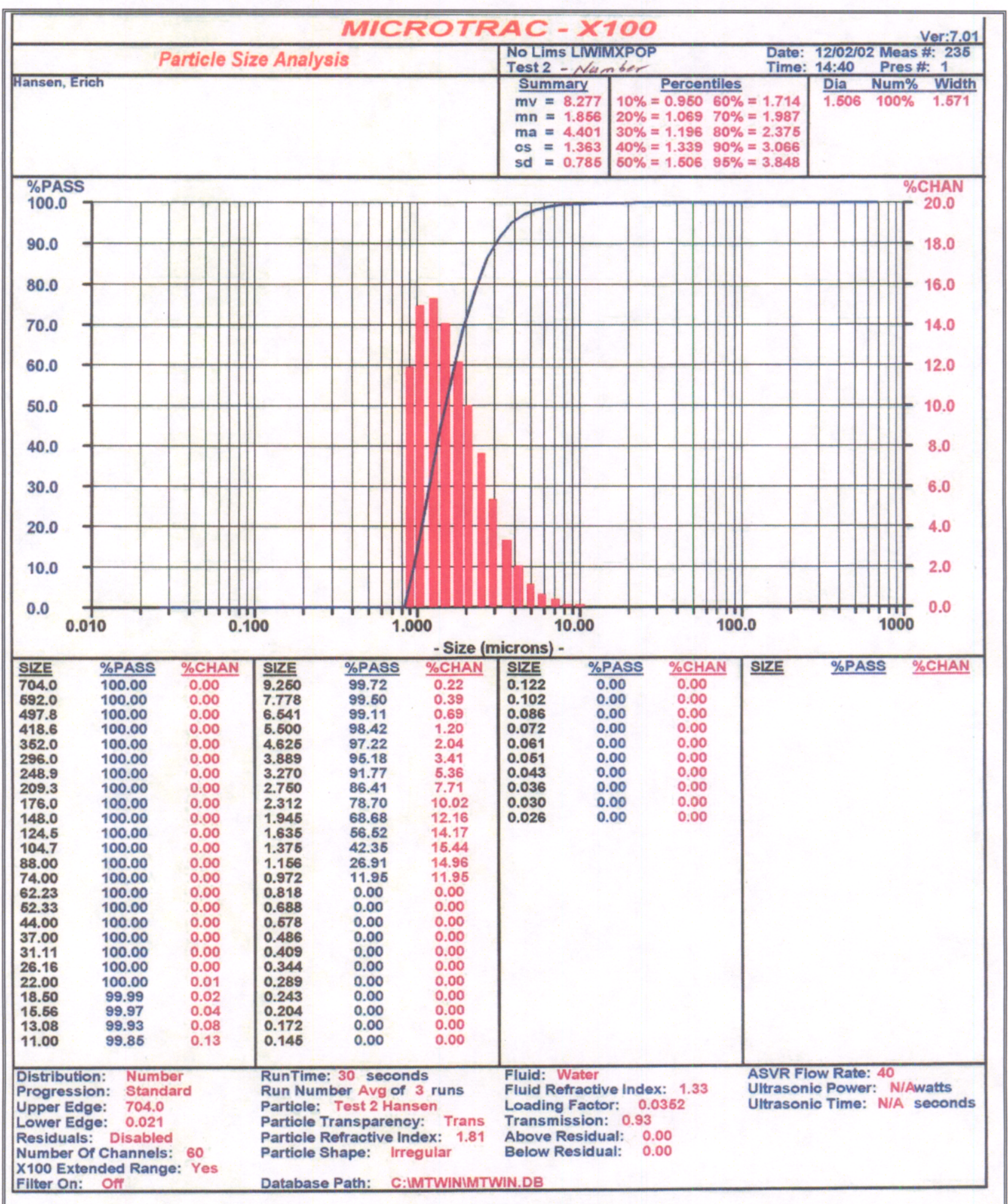


WSRC-TR-2003-00037, REV. 0

SRT-RPP-2003-00006, REV. 0

Figure D.9: SRA150 Volume Particle Size Distribution Second Run Filters

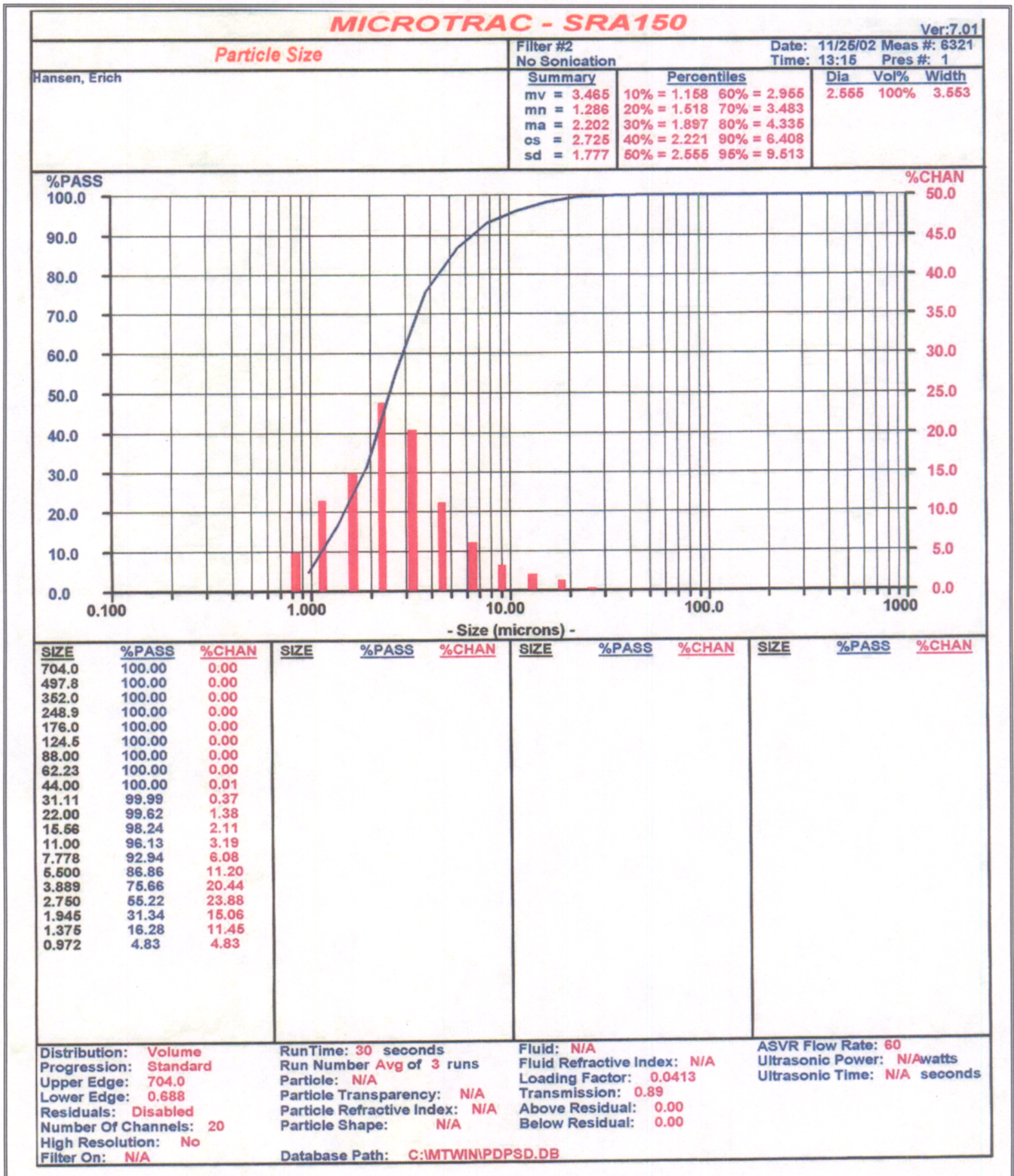


WSRC-TR-2003-00037, REV. 0

SRT-RPP-2003-00006, REV. 0

Figure D.10: SRA150 Volume Particle Size Distribution Second Run Filters

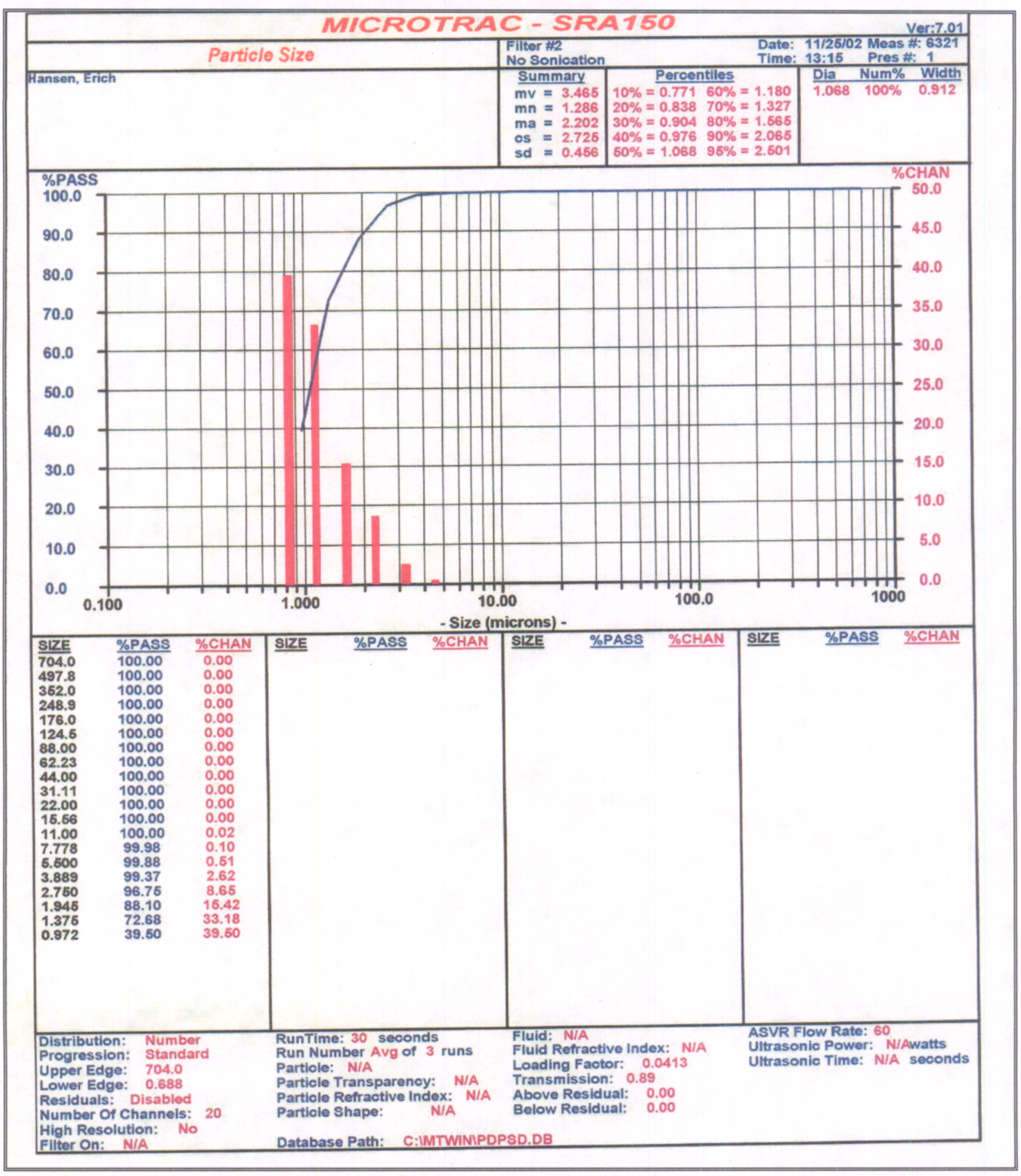


WSRC-TR-2003-00037, REV. 0

SRT-RPP-2003-00006, REV. 0

Figure D.11: X100 Volume Particle Size Distribution Second Run Filters

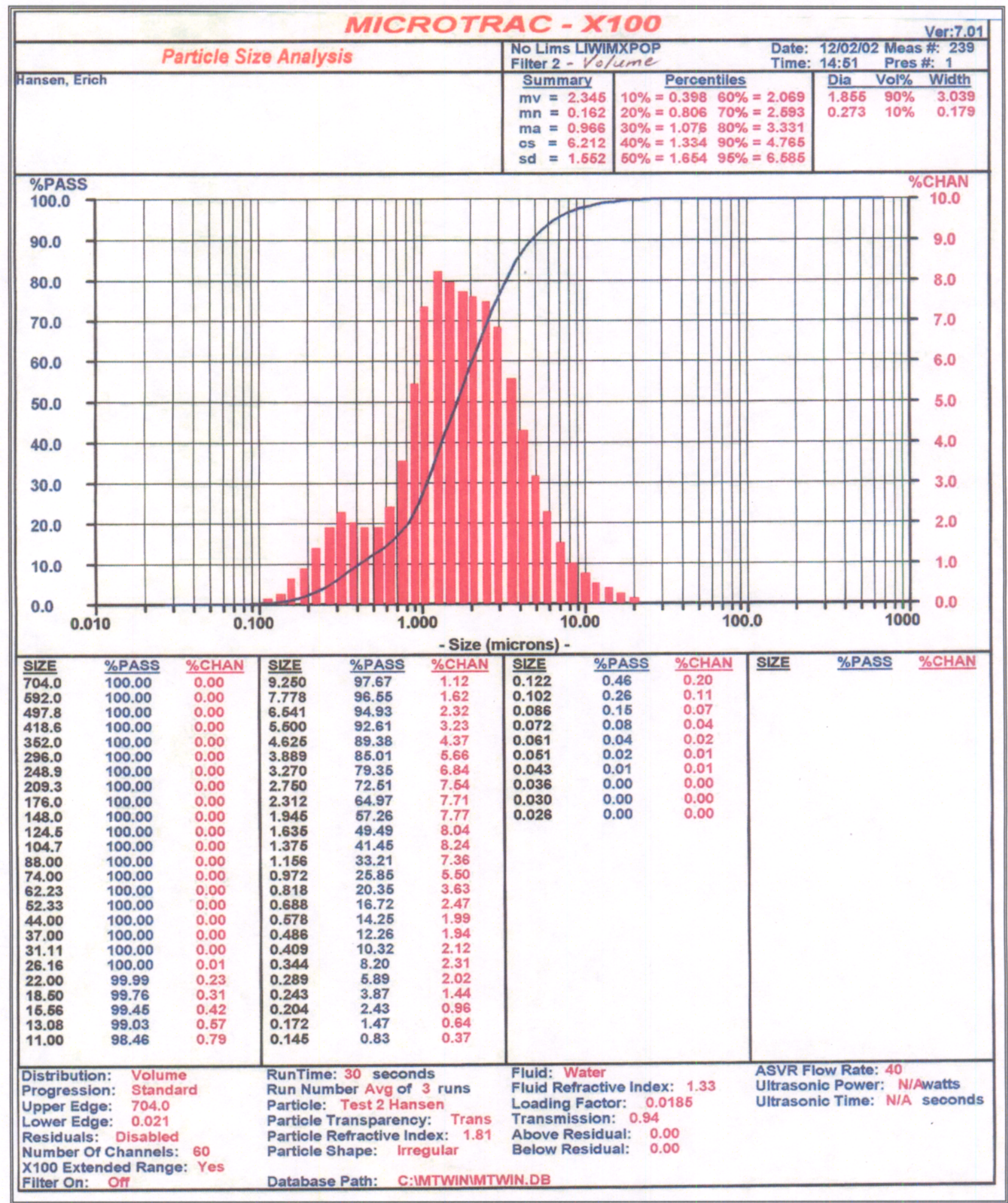


WSRC-TR-2003-00037, REV. 0

SRT-RPP-2003-00006, REV. 0

Figure D.12: X100 Number Particle Size Distribution Second Run Filters

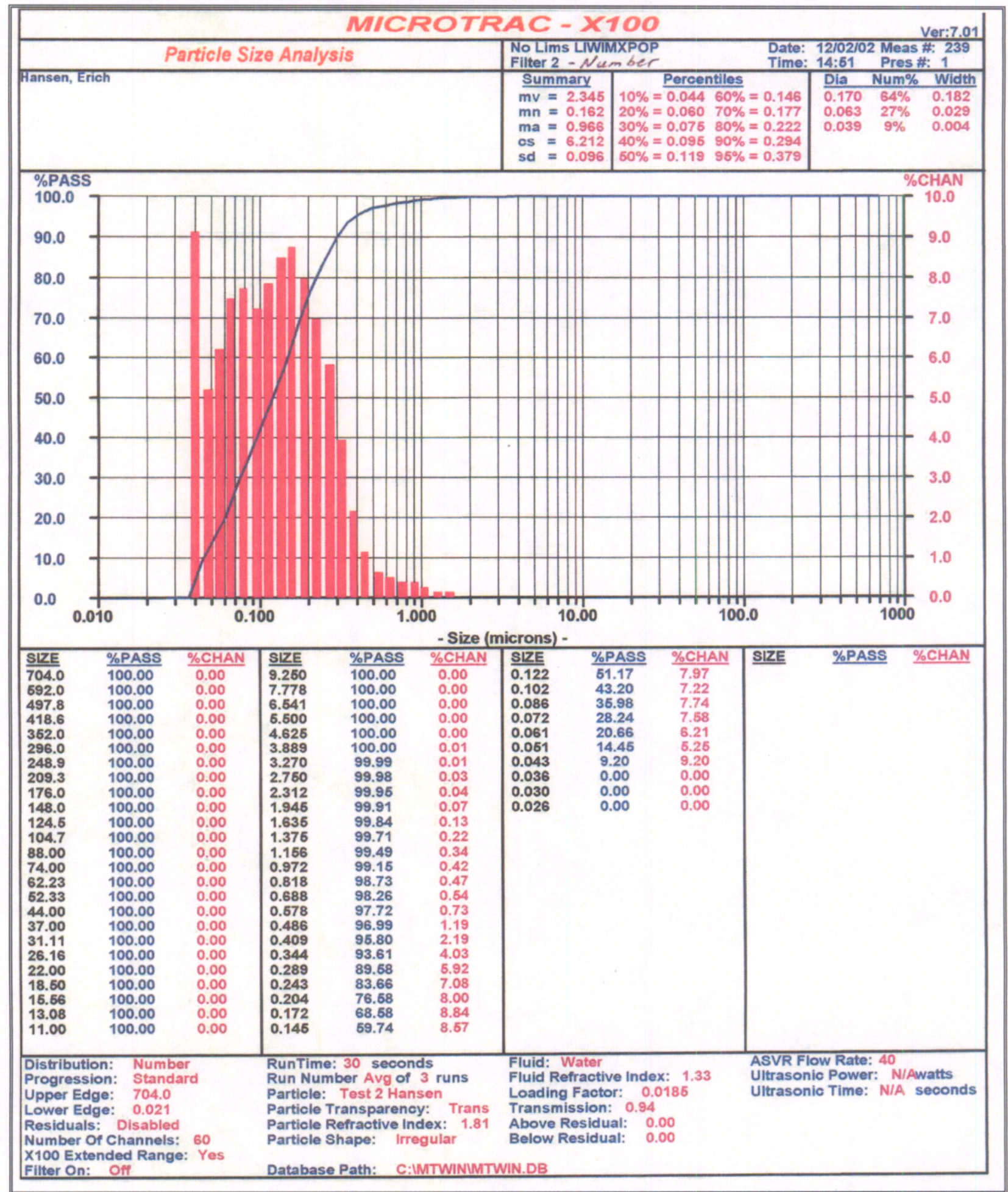

